\title{
Зигрун Комати
}

\author{
Сравнителен \\ структурен и фрункционален \\ анализ \\ на български и немски \\ публицистични заглавия
}

Verlag Otto Sagner München - Berlin - Washington D.C.

Digitalisiert im Rahmen der Kooperation mit dem DFG-Projekt „Digi20“

der Bayerischen Staatsbibliothek, München. OCR-Bearbeitung und Erstellung des eBooks durch den Verlag Otto Sagner:

http://verlag.kubon-sagner.de

( $)$ bei Verlag Otto Sagner. Eine Verwertung oder Weitergabe der Texte und Abbildungen, insbesondere durch Vervielfältigung, ist ohne vorherige schriftliche Genehmigung des Verlages unzulässig. 


\title{
SPECIMINA PHILOLOGIAE SLAVICAE
}

Herausgegeben von

Olexa Horbatsch, Gerd Freidhof und Peter Kosta

Supplementband 27

\section{SIGRUN COMATI}

\section{Сравнителен \\ структурен и функционален анализ}

\author{
на български и немски \\ публицистични заглавия
}

VERLAG OTTO SAGNER - MUNCHEN

1988 


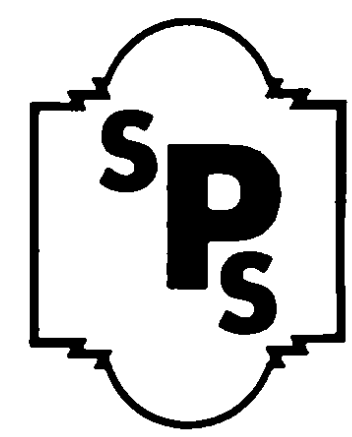

Bayerische

Staatsbibliothok Münchon

Copyright by Verlag Otto Sagner, München 1988.

Abteilung der Firma Kubon und Sagner, München.

Druck: Görich \& Weiershäuser, 3550 Marburg/L.

ISBN 3-87690-406-4

$$
\begin{aligned}
& 01959616= \\
& \text { Pgo/250? }
\end{aligned}
$$


Für Is abe ll 


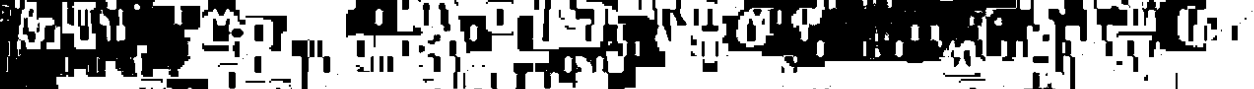

否

E. $\therefore$ a

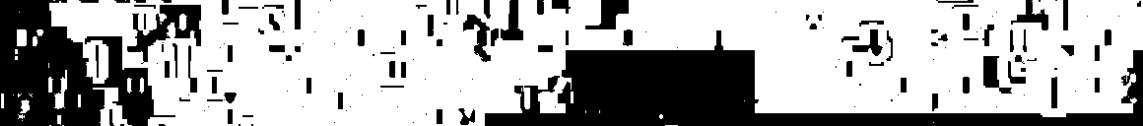

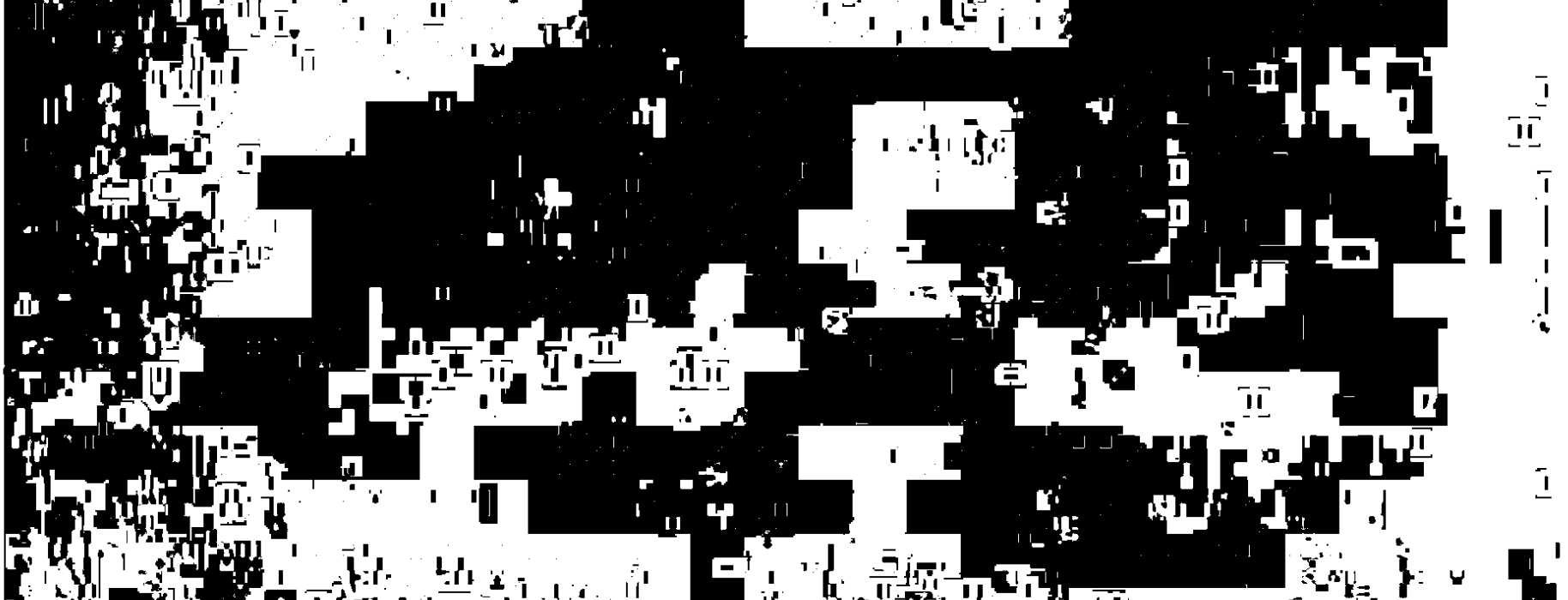
-

i

1

ing n

1

.

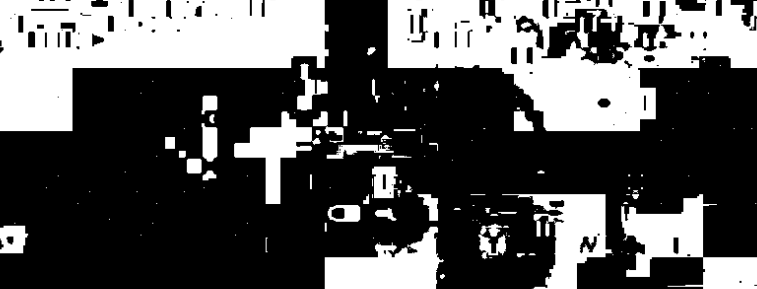

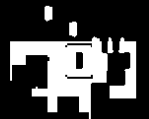

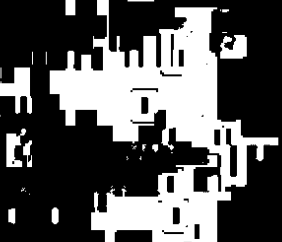

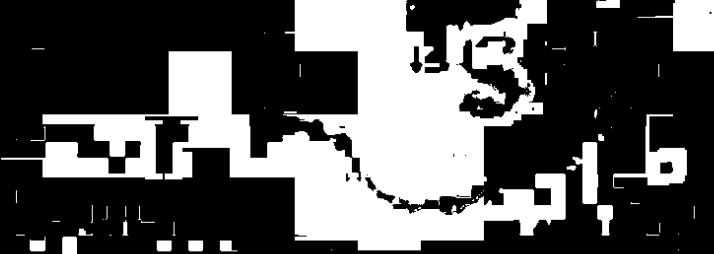

(1)

다년

$P=\frac{1}{2}$

1

ת

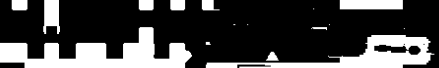

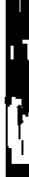

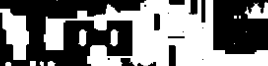

in 7

1)

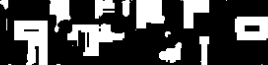

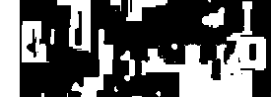

14:

1

Ti

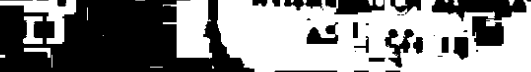

(1)

i1)

II

11.

ו.

Tiīinn

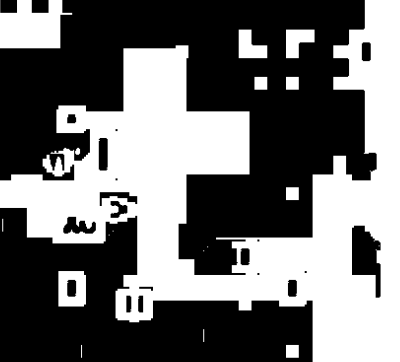

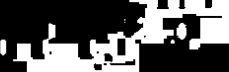

17

.

1.

$-1-$

PIn]

a

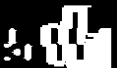

10

II

$=1$

$+1$

(1) (1)

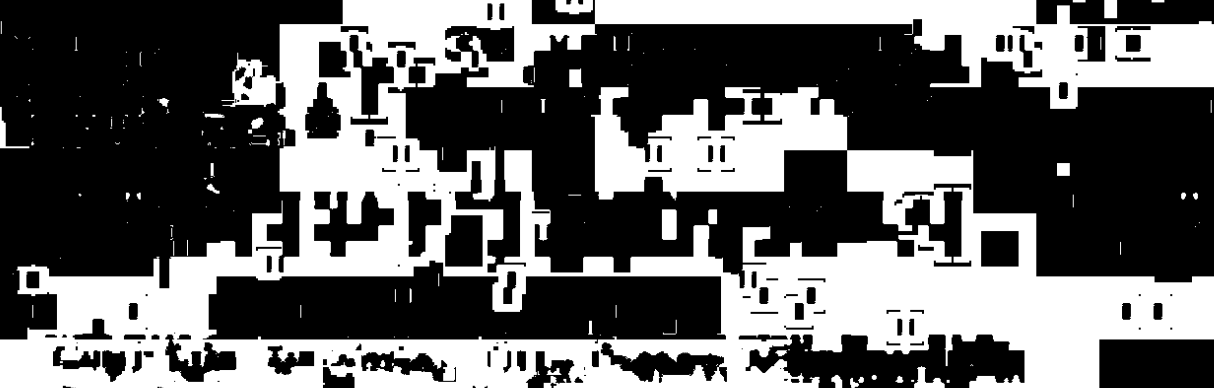

(1) of 1040

10 - 0

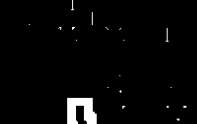

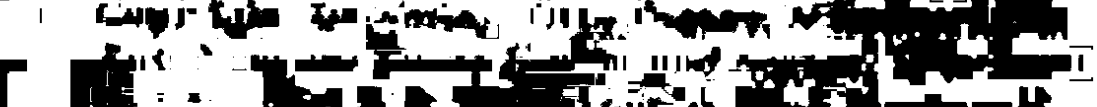

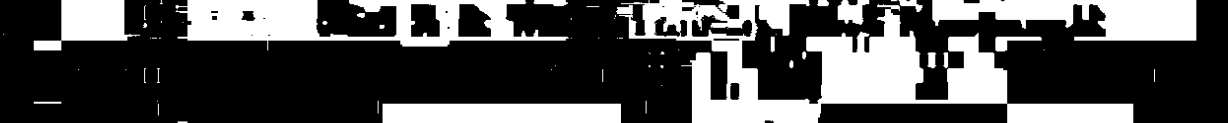

III 
Vorwort

Vorliegende Dissertation auf dem Gebiet des bulgarisch-deutschen Sprachvergleichs ist ein erster Versuch, die Schlagzeilen der bulgarischen und der DDR-Tagespresse nach grammatischen und funktionalen Aspekten zu systematisieren und Obersetzungsmöglichkeiten zu finden. Analyseobjekt dieser Arbeit sind ca. 8000 Schlagzeilen der Tagespresse in der Zeit von 1979-1986. Die Untersuchungsergebnisse sind praxisbezogen dargestellt und für Slavisten, Journalisten und für die Obersetzerpraxis von Interesse.

Die Dissertation wurde im Mai 1986 vor dem Professorenkollegium des Institutes für Sprachwissenschaft der Bulgarischen Akademie der Wissenschaften und dem Professorenkollegium der Fakultät für Slavische Philologien der Sofioter Universität "Kliment Ochridski" (Bulgarien) verteidigt und angenommen.

Mein Dank gilt Doz. Dr. Russelina Nicolova, meiner Betreuerin, und den Kolleginnen und Kollegen der Fakultät für Slavische Philologien der Sofioter Universität "Kliment Ochridski, des weiteren Doz. Dr. Russka Simeonova und Oberassistentin Hannelore Pančevska vom Lehrstuhl für Deutsche Philologie der Sofioter Universität für ihre hilfreichen Hinweise und die freundliche Unterstützung.

Mein Dank gilt auch Professor Dr. Gerd Freidhof, Slavisches Seminar der Universität zu Frankfurt am Main, der die Publikation der Arbeit angeregt und die Aufnahme in die Reihe befürwortet hat.

Frankfurt am Main, im Dez. 1988

S.C. 
1. Gutachter: Prof. Dr. Miroslav Janakiev, Universität Sofia

2. Gutachter: Doz. Dr. Vassilka Radeva, Universität Sofia

Tag der Verteidigung: 21.05.1986 


\title{
SIGRUN COMATI
}

\section{Сравнителен структурен и функционален анализ на български и немски публицистични заглавия}

\author{
Inauguraldissertation \\ zur Erlangung des Grades eines \\ "Kandidat na filologičeskite nauki" \\ an der Fakultät für Slawische Philologien \\ an der Sofioter Universität "Kliment Ochridski" \\ Bulgarien
}

vorgelegt von

Sigrun Comati

1986 
F

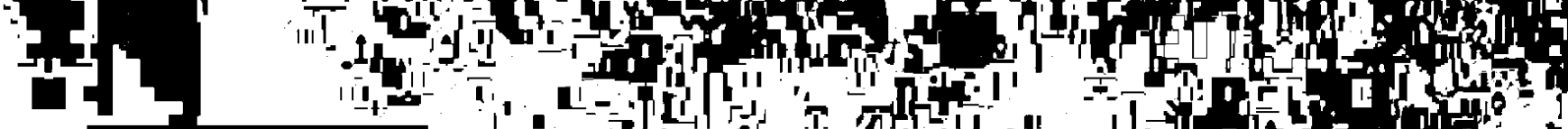

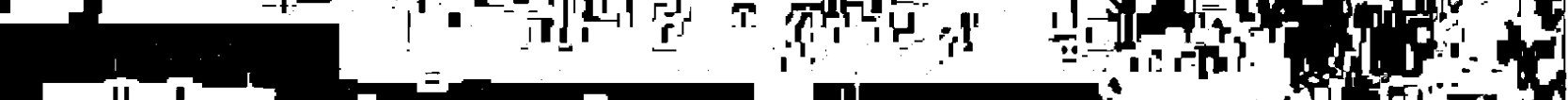

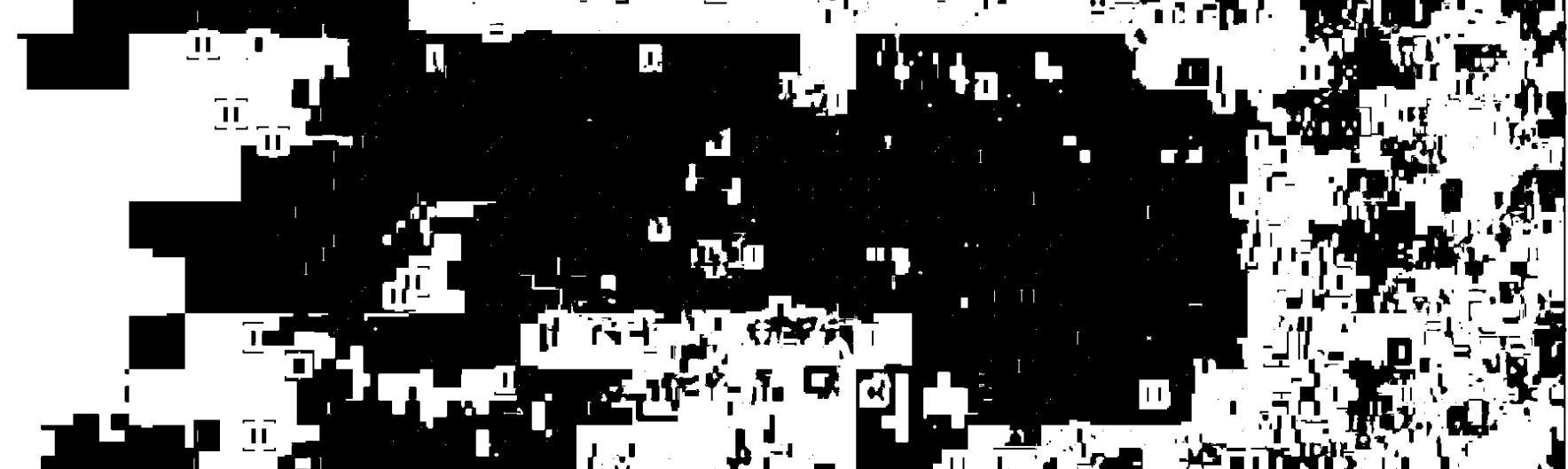
3. If

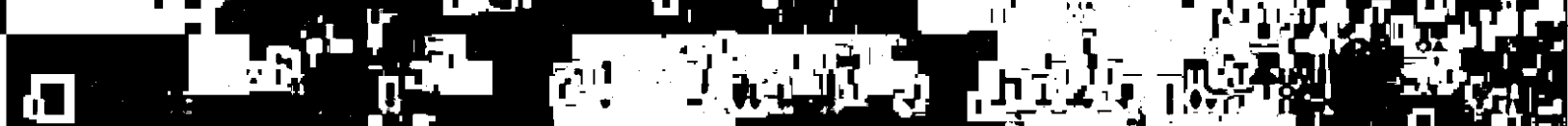
$4 a_{0} . b^{\circ}$

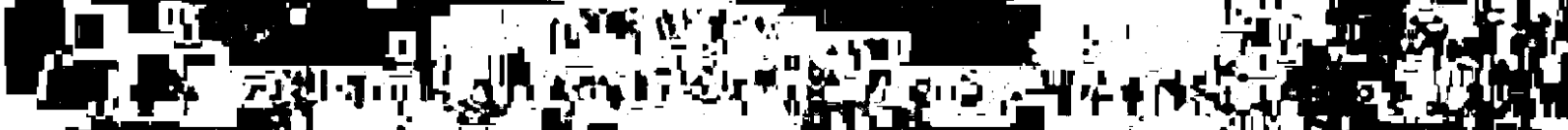
-72 and

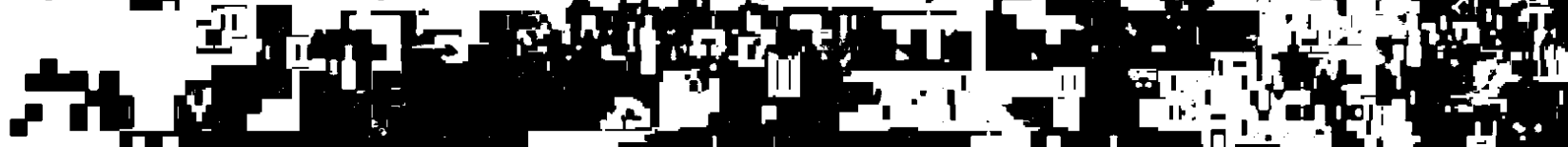

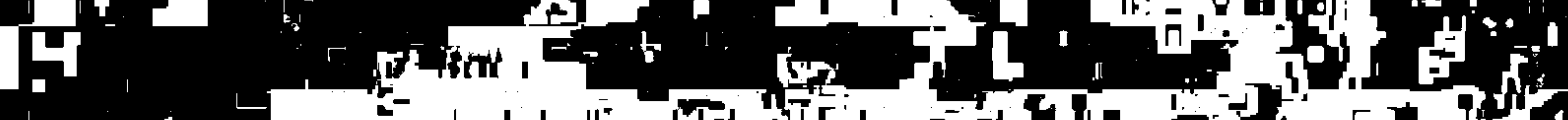

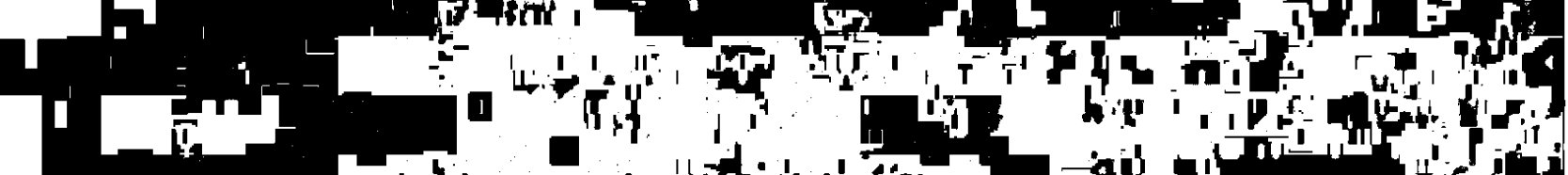
int T. Wh

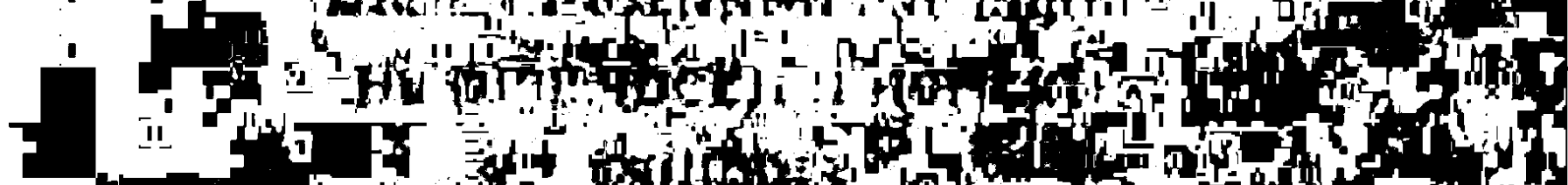
ind

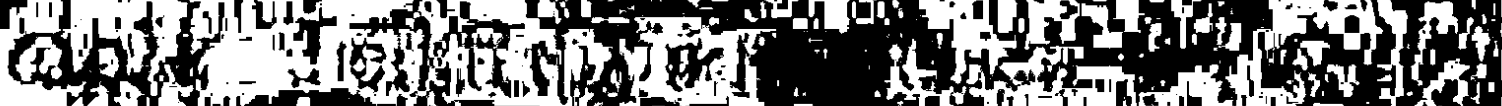
ing

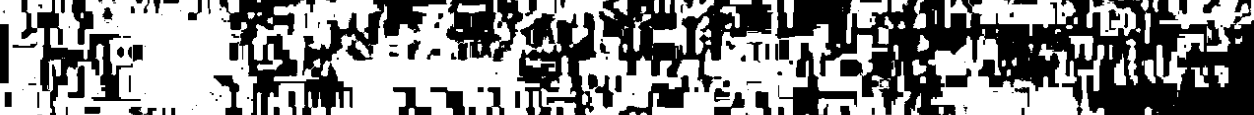
s. - ind 10 a d

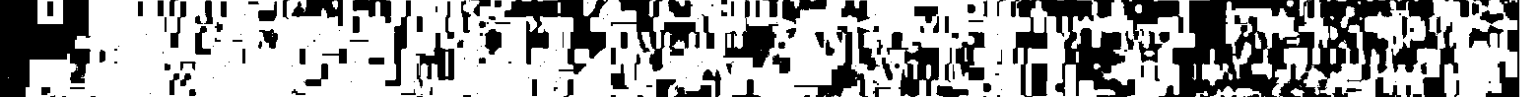
=hid

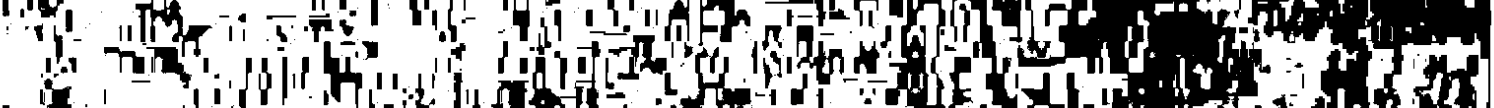

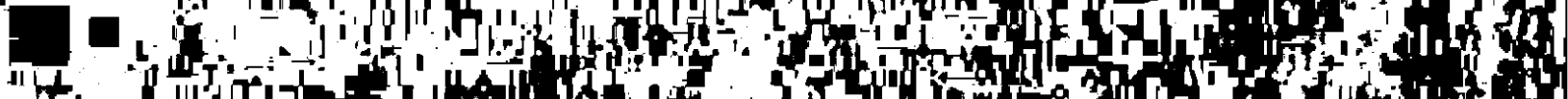
4.

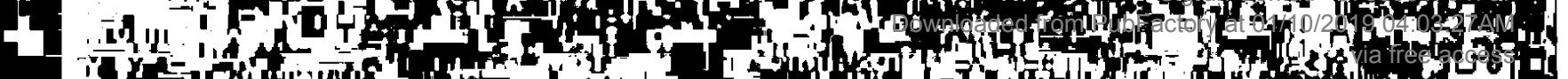

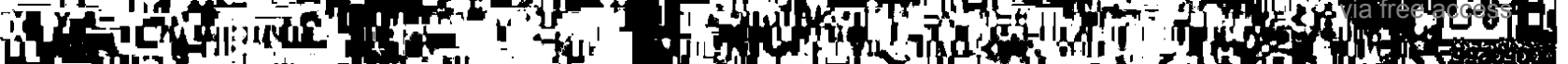


0 .

0.1 .

0.2 .0 .

0.2 .1 .

0.2 .2 .

0.2 .3$.

0.2 .4 .

1.1 .

1.1 .1

1.1 .2 .

1.1 .3

1.1 .4

1.1 .5 .

1.1 .6 .

1.1 .7 .

1.1 .8 .

1.2 。

Увод $\ldots \ldots \ldots \ldots \ldots \ldots \ldots \ldots \ldots \ldots \ldots \ldots \ldots \ldots \ldots \ldots \ldots$

Предмет и задачи на дисертацията ........ 8

Бележки към функционалния аспект на загла-

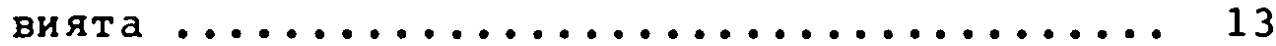

Номинативната Функция на публицистичните

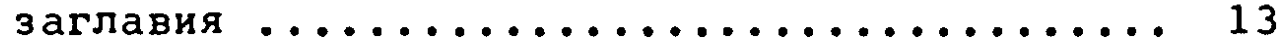

Информативно-комуникативната функция на публицистичните заглавия .............. 16 Призивната функция на публицистичните за-

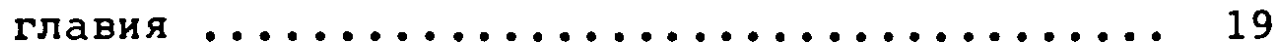

Подбудителна Функция на публицистичните

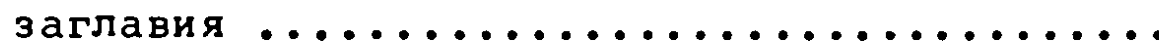

\section{Глава I}

Структурен анализ на българските публицистични заглавия ..................

Характерни особености и класификация на българските публицистични заглавия .......

Структурна класификация на българските и немските публицистични заглавия .........

Публицистични заглавия, които са по форма безпредложно-именни словосъчетания Публицистични заглавия, които са по форма предложно-именни словосъчетания

Публицистични заглавия, които представляват съобщителни изречения

Въпросителни изречения в публицистиката ... Подбудителни изречения като публицистични заглавия

Желателните изречения в публицистиката .... Незавъртени и непълни синтактични конструкция в публицистичните заглавия .........448

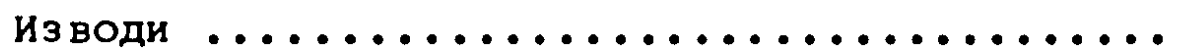


Глава II

2.0. Структурен анализ на немските публицистични заглавия ......................... 56

2.1. Уводни бележки към структурната класификация на немските публицистични заглавия .... 56

2.2 . Структурна класификация на немските публицистични заглавия ................... 59

2.2.1. Анализ на немски публицистични заглавия, които по форма са безпредложно-именни словосъчетания ........................

2.2 .2

Немски публицистични заглавия, които са по Форма прономннални словосъчетания ......... 62

2.2.3. Анализ на публицистични заглавия от немската преса, които са по форма предложно-именни словосъчетания ..................... 62

2.2.4. Немски публицистични заглавия, които представляват партиципиални и инфинитивни конструк-

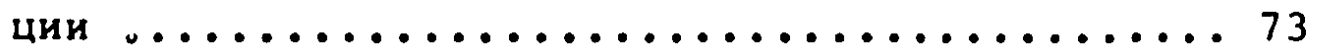

2.2.5. Елиптични изречения в немските публицистични заглавия с изпускане на спомагателния глагол .......................... 74

2.2.6. Немски публицистични заглавия, които представлярат пилии итрочонил ............... 74

2.3 .

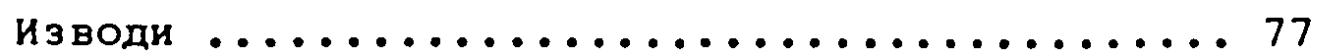

Глава III

3.0. Сравнителен анализ на българските и немските публицистични заглавия ................ 79

3.1. Съпоставителна таблица на главните групи на българските и немските публицистични заглавия .............................. 80

3.2 . Из води

Глава IV

4.0. Няколколко изследвания относно превода на бъл- 
гарските публицистични заглавия в немския

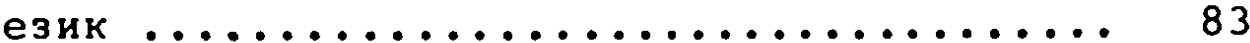

4.1 .

4.2 .

4.2 .1

4.2 .2

4.2 .3

4.2 .4

4.2 .4 .1

4.2 .4 .2 .

4.2 .4 .3 .

4.2 .4 .4 。

$4 \cdot 2 \cdot 4 \cdot 5$.

4.2 .4 .6 .

$4 \cdot 2 \cdot 4 \cdot 7$.

4.2 .4 .8 .

4.2 .4 .9 .

$4.2,4.10$.

4.2 .4 .11 .

4.2 .4 .12 .

4.2 .4 .13 .

4.2 .4 .14 .

Теоретични препоставки

Превод на публицистични заглавия, които са по форма безпредложно-именни словосъчетания от български на немски

Превод на публицистични заглавия от типа на $A+S$

Превод на публицистични заглавия, които представляват словосъчетания от числително име + прилагателно име + съществително име

Превод на публицистични заглавия, които представляват лично местомение + същест-

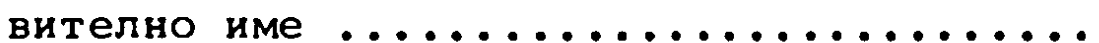

Превод на публицистични заглавия, които са по Форма предложно-именни словосъчетания от български на немски ...........

Превод на публицистични заглавия, които представляват предложно-именни словосъчетания С

предлог без ...................... 98

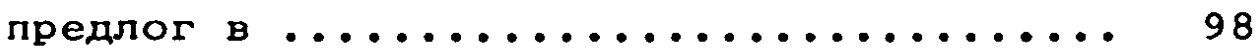

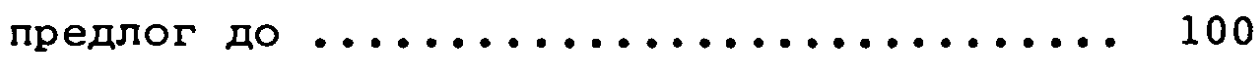

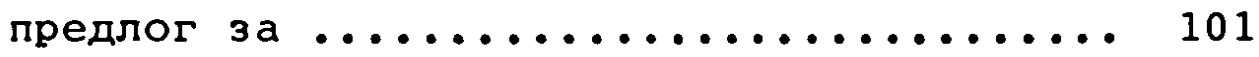

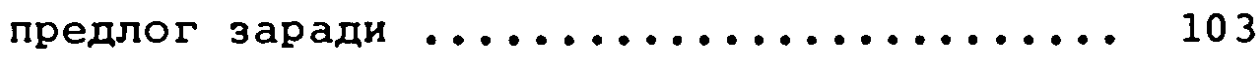

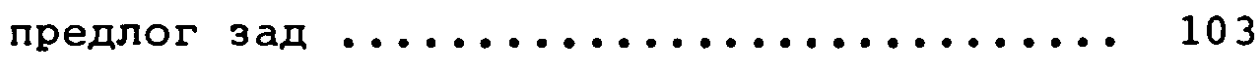

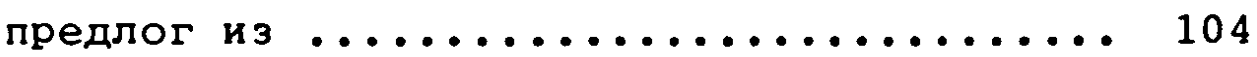

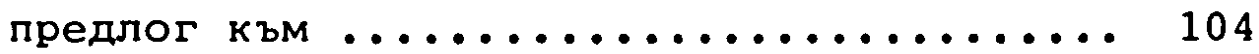

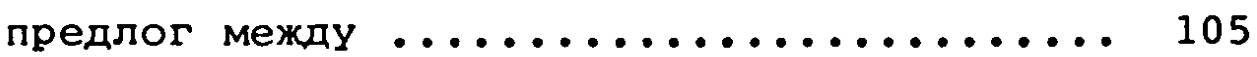

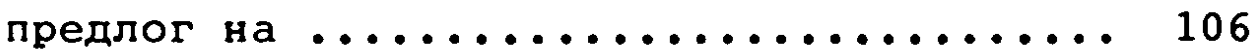

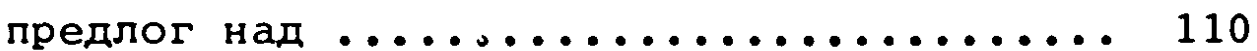

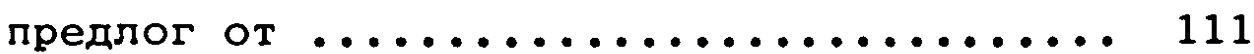

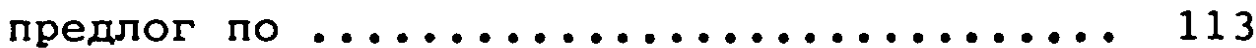

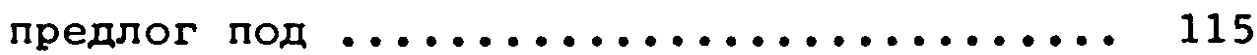


4.2.4.15. предлог пред ................... 116

4.2.4.16. предлог през ................. 117

4.2.4.17. предлог при .................... 118

4.2.4.18. предлог с ..................... 119

4.2.4.19. предлог след ................... 121

4.2.4.20. предлог сред ................... 122

4.2.4.21. предлог срещу .................. 122

4.3. Превод на български публицистични заглавия, които представляват да-форми ......... 124

4.4 .

Превод на непълни и незавършени синтактични конструкция в публицистичните заглавия ........................... 132

4.5

Теоретични бележки към словореда на немското съобщително изречение ......... 136

4.6 . Превод на публицистични заглавия, които представляват съобщителни изречения .... 140

4.7 . Превод на публицистични заглавия, които представляват въпросителни изречения ... 153

4.8 . Превод на подбудителни изречения като публицистични заглавия ........... 156

4.9 . Превод на публицистични заглавия, които представляват желателни изречения ..... 158 5.0 Заключение .................... 160

Библиография .................... 164 
0. УВОД

Вестниците, списанията и голям брой периодични научни издания в социалистическите страни са една неделима част от наmето ежедневие. Броят на печатните материали, които се публикуват периодично, непрекъснато нараства. Периодичният печат, преди всичко вестниците, които заедно с радиото и телевизията образуват главният източник на информация на голяма част от населението, непрекъснато се увеличава. В книгата си Костомаров /1971/ посочва специално, че ежедневниците в натето общество трябва много високо да се оценяват като средства, които изграждат мнението на читателя и едновременно го възпитаBat.

Връзките между НРљ и ГДР стават все по-тесни, това се отразява и върху все по-увеличаващата се размяна на информация между нашите държави в областта на политиката, икономиката и науката.

Въз основа на това, че броят на публицистичните материали непрекьснато се увеличава, може да се установи специално за последното десетилетие една нарастваща тенденция на лингвистичните изследвания в областта на публицистиката. В българското езикознание такива изследвания съествуват в много малък брой до сега: Андрейчин /1961/и /1973/. Тези разработки изразяват едно критично отношение към езиковата култуpa на публицистиката. Брезински /1976, 1979/ се спира главно върху стилистични проблеми на публицистиката. Ставровски /1958/ обръща внимание върху правилната употреба на думите, специално в публицистиката, с оглед на тяхната семантика. В статията на Кърпачева и михайлова /1975/ темата за езика на публицистиката само се докосва и в статията на Пеев/1975/ темата е насочена към правилната употреба на чуждите думи във вестниците. В публикациите на Пилер/Комати//1981/ наблюденията върху българските публицистични заглавия се систематизират преди всичко в синтактично-структурен план и се сравняват с немските публицистични заглавия. В статията на Стоянова - Иовчева и златева /1984/ въпросите на българските и 
немски публицистични заглавия се разглеждат в синтактичен аспект. Едно по-подробно и обширно изследване на публицистичните материали все още не съществува, а това е необходимо, за да се систематизират главните явления и особености на публицистичните материали, което ще бъде от полза не само за езиковеди, но и за журналисти. В публицистиката се установява една много положителна тенденция към подобряване и разнообразяване на заглавията. Явления като езиков шаблон са рядкост, това несъмненно се дължи на по-качествената подготовка на журналистите. В статията си Костомаров /1965/ посочва, че употребяваните структури на заглавията във вестниците отразяват "вкуса" на един период, нагледно представят тенденциите в еволюцията на езика.

Важна роля в публицистиката играе заглавието, което е предмет на тази работа. Както е известно, вниманието на читателя се концентрира най-напред върху заглавието, по-късно върху статията. Така и авторите Розенталь и кохтев /1981/ в раз работката си установяват, че брочт на читателите, които четат само заглавията, е пет пъти по-голям от броя на тези, които четат статията. Вундерлих /1975/ в своята книга посочва даже още по-голям брой на "читателите на заглавията".

Заради тези особености изследването на публицистич-

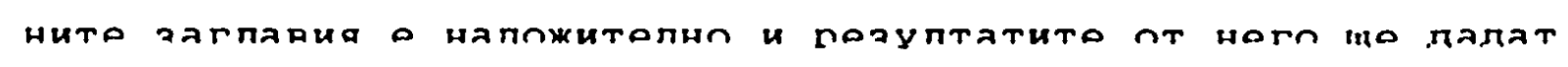
на само данни за съвременното състояние на българските и немските заглавия в лингвистичен аспект, но ще служат и на журналисти, говорещи немски като роден език и които имат познания по български език да преведат българските заглавия точно с оглед на немската езикова практика, тъй като на превода е отделено много внимание в тази работа.

Конкретната цел на тази разработка е точен и подробен анализ на българските и немските публицистични заглавия на най-големите вестници в нР България "Работническо дело" и "народна младеж" и в Германската Демократична Република "Neues Deutschland" и "Junge Welt".

Едно публицистично заглавие трябва да изпълнява съвсем 
определени изисквания. Така Сафонов /1981/ твърди, че публицистичните заглавия, за разлика от теми в телевизията или радиото като комуникативна единица, информират читателя концентрирано за съдържанието на статията, изразяват нейната тематика, ранга и характера на нейното съдържание, което пък от своята страна се отразява върху номера на страницата, на която е напечатено заглавието. 
0. 1. ПРЕДМЕТ И ЗАДАЧИ НА ДИСЕРТАЦИЯТА

Във връзка с поставената цел заглавията се изследват в сравнителен план относно тяхната функция в публицистиката. Вариантите на превода на българските публицистични заглавия на немски се представят с оглед на тяхната специфична функция. А задачите, конто ще допринесат за постигането на тази цел се формулират така:

1. Разглеждане на българските публицистични заглавия /в граматико-фцнкционален план/

2. Разглеждане на немските публицистични заглавия /в граматично-Функционален план/

3. Сравнителен анализ на българските и немските публицистични заглавия

4. Разглеждане на въпроси за еднодирекционния превод на българските заглавия на немски

5. Ориентация към някои тенденции в развитието на българските заглавия на немски език въз основа на направените наблюдения.

За дисертацията са събрани и анализирани общо 8000 заглавия от 1979 Г. до 1985 г., от тях 4000 са от най-големите вестници на НРБ, органа на Централния комитет на БКП "Работническо дело" и органа на Централния комитет на ДКМС "Народна

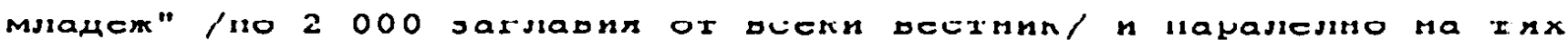
- 4000 заглавия от най-големите вестници на ГдР - "Neues Deutschland" орган на Централния комитет на ГЕСП и органа на Централния комитет на младежкия съюз Снм на Гдр "Junge Welt", пак по 2000 заглавия от всеки вестник.

Специално внимание се обръща върху темите, свързани с вътрешната и външната политика, като се имат предвид не само самите съобщения, но и мнения, становища и интервюта за определени политически събития. Така че се разглежда една тематична област, представена с различни журналистични жанрове, за да се обхване по-голямо разнообразие на заглавията.

Количеството на анализираните заглавия дава право да се 
направят обобщения за тенденция на развитието в двата езика.

Въз основа на тези задачи дисертацията е разпределена на пет глави.

В пьрвата глава се разглежда граматико- синтактичната структура на българските публицистични заглавия с оглед на някои ФУнкционални аспекти. Установява се, че в съвременната българска публицистика като заглавия се предпочитат субстантивни словосъчетания / разглеждам синтактичната структура словосъчетан: въз основа на неговата дефиниция от Попов /1974, стр. 30/ "Словосъчетанието е съединение най-малко на две самостоятелни, пълнозначни думи, конто образуват смислово и граматично единство" и най-вече предложно-именни словосъчетания. Чрез подробния анализ на този тип заглавия се посочва ясно, кои предлози в съвременния български език се употребяват най-често и при кои предлози се явява намаляваща употреба. Обръщам внимание на десемантизацията на най-разпространените български предлози на, за, от, из, с, по и др. Повече от половината на предлозите, кои. то се срещат в звглавията имат две, три и повече значения. това явление от своя страна играе голяма роля при превода. При публицистичните заглавия, които са по форма прости Съобщителни изречения се открива голямо разнообразие. Разглеждам словореда им, който при българските публицистични заглавия е малко по-свободен. Граматикализацията при тях не е окончателно установена, което позволява по-голяма свобода и Гъвкавост при изреченията, това явление се отразява положително върху публицистиката, тъй като позволява различни изразни възможности и варианти при оФормянето на публицистичното заглавие.

Върху граматичните особености на съвременния български език, които се отразяват разбира се и върху оформлението на заглавията, обръщам специално внимание.

Този анализ ясно подчертава аналитичния характер на съвременния български език и посочва тенденции в неговото развитие.

Втората глава от работата разглежда заглавията на най- 
големите вестници на ГДР "Нойес Дойчланд" и "Юнге Вельт" в структурно- синтактично отношение. Разглежда се тенденцията към номинмлизация и езикова икономия, обръща се внимание на вербалнитеь партиципиалните и инфинитивните конструкции, които в немския език са по- Фреквентни. Синтактичният характер на немския език е ясно изразен чрез рекцията на отделните предлози и глаголи. Чрез този анализ се подчертава кои предлози в немския език са най-натоварени и десемантизирани и какви отношения изразяват. Разглежда се и въпросът за апозиционните синтагми, чиято употреба нараства и по този начин пак сигнализират една тенденция на езиковото развитие.

третата глава е посветена на сравнителния анализ. Съветският германист В. Т. Адмони изяснява, че съпоставката с други езици позволява да се види особеното и своеобразното в един език. В противен случай според Адмони лингвистът е изложен на опасносттса, да пропусне много съществени черти от изследвания език Адмони /1974/. Същото мнение е изразено и от А. 3. Исаченко /1962/. Така съпоставителното изследване на езиците трябва да се схваща не само като метод за получаване на нови данни за системата на отделните езици.

Сравнителният анализ на българските и немските публицистични заглавия посочва главните сходства и различия между тях. Изводите от анализа, които се основават върху точни наб-

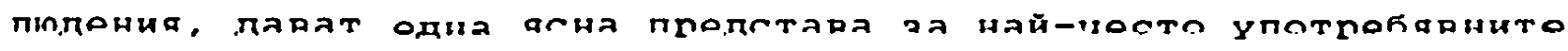
видова заглавия в двата езика.

В четвъртата глава на дисертацията разглеждам въпроси, на превода на български публицистични заглавия на немски.

Преводът на заглавия от статии на вестници е не само важна, но и отговорна задача. Важна е, защото по този начин читателите в другите държави получават ценна информация за външните и вътрешнополитическите събития на страната, а ролята на превода е много отговорна в това отношение, защото по този начин трябва да се запази диалектичното единство между съдържание и форма. Изключително важно е да се направи един точен превод, който предава не само самото съдържание, но и 
призивния характер на заглавието. Тази задача изисква една солидна подготовка на преводача, който трябва да владее отлично Българския и немския език, да има добри знания по странознание и трябва да бъде винаги информиран за актуалните събития.

При превода на публицистични заглавия преводачът трябва да държи сметка за практиката в своята страна при оформянето на публицистични те материали и в съответствие с тези изисквания да направи прагматично-семантичния избор на елементи от статията, които трябва да влязат в заглавието, също така и за семантичното му оформяне. При превода е необходимо, да се изяснява, какво е "обичайното", "приетото" за даден език в определена страна. Преводното заглавие трябва да изпълнява същите функции, както заглавието в оригинала, но не винаги със същите средства. Така например в българските заглавия причастните конструкции се употребяват по-рядко, а в немските заглавия те са толкова често срещнато явление, следователно преводачът трябва да превежда с тях често. Тъй като употребата на елементи от разговорната реч в заглавията като стилистичен ефект в българския език е много малко застъпена, следва да се обърне внимание при превода на публицистичните заглавия на чужд език, където това явление е по-застъпено /например немски, английски /.

Относно синтактичната структура на преводното заглавие преводачьт трябва да се съобразява с това, с което е "свикнал" съответно читателят, например в аналитичния български език около 708 от всички заглавия представляват именни словосъчетания/предложни и безпредложни/, степента на номинализацията е много висока, докато в синтетичния немски това положение е различно за сметка на глаголните и причастните словосъчетания.

При превода на българските заглавия на немски език трябва да има един цялостен подход към тази задача. Преди всичко трябва да се обърне внимание на семантичния и призивния компонент. Един превод, който се ориентира само по граматичната структура, няма да бъде точен. Семантичното съдържание, 
призивният характер и граматичната структура трябва да образуват едно диалектично единство както в българското оригинално заглавие, така и в немския превод. Многобройните примери на превода на отделни видове български заглавия на немски потвърждават този комплексен подход.

Петата глава на работата съдържа заключения и изводи въз основа на резултатите от изследванията и наблюденията върху българските и немските публицистични заглавия в граматичен, синтактичен, семантичен и функционален аспект.

изследването на българските и немските публицистични заглавия с оглед на превода на българските публицистични заглавия на немски е полезно не само в сравнителен план, но допринася и за описанието на отделните съпоставяни езици.

В това отнотение тази дисертация ще бъде един принос към съпоставителното изследване не само от гледна точка на теорията на превода и на чуждоезиковото обучение, но и по отношение на езиковата типология. 
0. 2. 0. БЕЛЕЖКИ КЪМ ФУНКЦИОНАЛНИЯ АСПЕКТ НА ЗАГЛАВИЯТА

0. 2. 1. НОМИНАТИВНАТА ФУНКЦИЯ НА ПУБЛИЦИСТИЧНИТЕ ЗАГЛАВИЯ

Според моите наблюдения всяко заглавие в ежедневниците и въобще на публицистичните материали изпълнява четири функции:

1. Номинативна Функция /назоваване на статията/

2. Информативна Функция/из разява най-съиественото от съдържанието на статията, информира чрез представяне на ситуацията/

3. Призивна Функция /да предизвиква и привлече вниманието на читателя/

4. Подбудителна Функция /да предизвиква определена реакция, да изразява закана към действие, към изводи и оценка от страна на читателя/.

У някои автори, като Радке /1982/, Васева /1985, стр. $110 /$ намираме схващането, че публицистичните заглавия освен тези Функции имат още и рекламна Функция, но аз не се присъединязам към него, защото не може да се разглежда заглавието като реклама на статията, тъй като във всяка реклама се препоръчва употребата или купуването на някакъв продукт, който е в центъра на рекламата. Това потвърждавт и изследванията на Вундерлих /1975/ и Рьомер /1968/ относно езика на рекламата. Главнвта задача на публицистичните заглавия е да съобщават за събитията, личности и др., нещо, което предизвиква представа за ситуация у читателя.

Към номинативната Функция на заглавията трябва да кажем следното: Независимо от граматичнатаси структура, заглавието назовава следващата след него статия, даже може да се каже, че в известна степен от тази гледна точка можем да сравним заглавието със собствените имена, които назовават един индивид, без да посочват по-конкретно неговите качества. Но за разлика от собствените имена публицистичното заглавие се насочва повече към съдържанието на статията.

Механизмът на назоваването на ситуацията и механизмът на комуникативната задача са много тясно свързани. Номинатив- 
ната /назоваващата/ и комуникативната страна на езика в заглавията се отразяват най-ярко. Често пъти е трудно да се определи, коя стрна на езика - номинативната или комуникативната е основен фактор на заглавието. Ако комуникативната страна е на преден план, принципът на разчлененността не позволява да се събират повече от две съставни части в заглавието. Това е едната част, която съобщава, и другата част е, за какво се съобщава. След разглежлане на много заглавия на посочените вестници се установи, че всяка от тези две части може да се покаже в съкратена и синтагматично разширена форма.

обаче номинативното схващане за публицистичното заглавие /то впрочем нерядко се явява във форма на изречение/ прехвърли проблемът вече на семантично равнище, където трябва да се обърне внимание и на прагматични Фактори, които имат основна роля при оформянето на заглавието.

При заглавия, където номинативната функция стои на преден план, максимата на Розенталь /1980/ за публицистичните заглавия - "За единица време - максимум информация" е особено актуална. Такива заглавия са съкратени до минимум, напр.: "Младежка инициатива" Рд 18.01.84Г. 6р. 18, "Предстоящо посешение" РД 26.01.84Г. бр 26, "Извънредна сесия" РД 22.01.84 Г. 6р. 22, "Конструктивно предложение" Рд 10.02. 84 г. 6р. 41, "Политическо убийство" РД 06.01 .84 г. бр. 6, "Сьвременна кониертна зала" РІІ 18.01.84Г. бр 18.

Понятието за номинацията, както е застъпено в нашето езикознание е дефинирано и разработено от Уфимцева/1977, стр. 86/ "Так, номинативная и сигнификативная функция представляют по своему содержанию две стороной одного и того же явления знаковой репрезентации слова как дискретной единицы языковой системы и характернцй, прежде всего, для номинативных словесных знаков."

Тук ще разгледаме няколко особености на българския език, които се отразяват и върху номинализацията в публицистичните заглавия:

1/ Както е известно, в съвременния български език липсва 
такава инфинитивна форма на глаголите, която съшествува в немския език. Тази инфинитивна форма е изчезнала в историческото развитие на българския език. Интересно е, да се види сега, ак се компенсира "отпадналия" инфинитив, с какви езикови средства. Липсата на инфинитивната форма на глагола в българския език естествено се отразява при формулирането на публицистичните заглавия. В съвременния български книжовен език каго една от компензационните възможности на липсваша инфинитивна форма на глагола бихме могли да разберем отглаголните съществителни. Примери: "Завръщане в родината" Рд 04.11.83г., Чествуване на сътрудничеството" Рд $07.11 .835 .$, "Плащане ... без пари" РД 09.11.83г., "Препи всичко добро планиране" РД 10.11. $83 г .$, "За разииряване на сътрудничеството" Рд 10.11.83г., "Принос в историческата битка за запазване на мнра и живота" Рд 10.11.83г.,"Автоматизацията - верен път за подобряване на транспортното обслухваке на народното стопанство и населението" РД 11.11.83г.,"Призивът за високо качество - ориентир за мобилизиране на младото поколение" Рд $11.11 .83 \Gamma$.

Замяната на инфинитива с отглаголно съществително в определени и посочените тук примери е съвсем оправдана от семантична гледна точка, обаче "образуваните от несвършена глаголна основа съществителни на -не притежават ясно изразена глаголност и представляват истински съществителни за деиствие"/Георгиева 1976/. и отглаголните съществителни на -не са езиково средство за компензация на липсващата в съвременния български език инфнитивна форма на глагола. Отглаголните съществителни на - ние семантично се различават от отглаголните съществителни на -не, поради това, че означават едно деиствие или един процес и трябва да се разграничават от формите на -не много ясно. Трябва да се обърне внимание върху тяхната правилна употреба в пцблицистичното заглавие. Примери: /членувани/ "Очарованието на пеизажа" Рд 10.01.84, "Решението на Сирия" РД 04.041.84r., /нечленувани/ "Преклокение пред подвига" Рд 16.01.84, "Соревнование между братя" Рд $15.01 .84 \mathrm{r}$., "С внимание и надежда" Рд $17.01 .84 \mathrm{r}$. "Вззмущение срещу насилието" РД 17.01.84г., "Кон- 
структивно предлохение на Кореиската Демократична Република" РД 12.01.84Г., "Признание на голямото изкуство" РД 10.01.84Г., "Заседаниевъв Варшава" РД 20.01.88г., "Вдохновение, вградено в линии и багри" РД 20.01.84Г.

Отглаголните съществителни на - ние се срещат сравнително често в такива публицистични заглавия, които граматичната си форма представляват предложно-именни словосъчетания или изречения. И двете Форми - инфинитивът и отглаголното съществително - изразяват глаголното дейтвие без отношение към определено лице, число и време. С това искам да приключа забележките за номинативната Функция на публицистичните заглавия и да обърна внимание върху втората им Функция - информативнокомуникативния аспект нв публицистичното заглавне.

0. 2. 2. ИНФОРМАТИВНО - КОМУНИКАТИВНА ФУНКЦИЯ НА ПУБЛИЦИСТИЧНИТЕ ЗАГЛАВИЯ

Трудно е, да се разглежда информативно-комуникативната страна на публицистичното заглавие отделно от другите Функции на заглавието. Съцо така анализ не може да се направи, ако не се обръща внимание на граматичната структура. Тези критерии образуват едно диалектическо единство, защото информативно-комуникативната структура се представя чрез граматико-синтактичната структура, тя е намерението / интенцията/ на говорещия да предизвика определен комуникативен ефект - да съобщи нещо, да запълни празнота в информацията си, да предизвика някакво деиствие.

Костомаров /1971/ посочва особените черти на предаването на информацията във вестника по следния начин, като обръща специално внимание върху масовостта на пресата: Първо, той описва характерните моменти на вестникарското творчество: периодичност, едномоментност н високия темп на производството. После той твърди, че журналистичния език ориентира към експресия, а вестникът изисква един определен стандарт. Значи моделът на езика на вестниците се състон в съотношение на стан- 
дартизирани и експресивни елементи на речта. От друга страна, масовостта на вестника е обусловена от различните речеви навици на питещите, т.е. авторите се приспособяват едновременно към общите речеви навици на масата на читателите. Речта на журналистите се различава от тази на белетристката с нейните "езикови персонажи" и "авторската реч" изцяло.

Заглавието на вестника информира читателя за съдържанието на статията. Например, когато четем заглавнето "Blutbad in San Salvador" 24.05.79г., на български "Кървава баня в Сан Салвадор", веднага се изгражда в нашата представа едно ужасно събитие, битка с много жертви. Авторът, който участвува в комуникационният процес, чрез тази Функция встъпва в комуникативна връзка с читателя,/Арндт, 1980/. Най-информативни са тези тези заглавия, конто по структура са пълни изречения, те заемат в моите наблюдения около 208, като например: "Ръчният труд намалява" РД 10.02.84Г., "Равнището задължава" Рд 22.01.84Г., "Необявената война продължава" Рд 11.01.84Г. Подобно е положението и в руския език, както показва изследването на Попов /1966/ върху структурата на съвременни заглавия на вестници и нейното развитие. Особено двусъставните изречения притежават висока "информативна стойност".

Висока комуникативна стойност притежават подбудителните изречения, които изразяват заповед, те пряко въздействуват върху читателя. Примери: "Не се лекувайте сами!" Рд 14.10.80г., "долу ръцете от Гренада!" РД 04.11.83г., "не бива да бъдем равнодушни!" Рд 06.11.83г., "не както можеш, а както трябва!" РД 08.01.84Г., "Да защитим живота, докато не е късно!" Рд $10.11 .83 \mathrm{r}$.

Принципът на езиковата икономия в много случаи води до публицистични заглавия, които по структура представляват непълни изречения или само именни словосъчетания с най-различна структура. Особено тези отклонения от нормата "пълно изречение" показват в различните примери голямо разнообразие. /Тази таблица се отнася към българските публицистични заглавия./ 
таблица
В $и$ д
Брой
Процент

1. Безпредложно-именни словосъчетания

2. Предложно-именни словосъчетания

1890

47,28

3. изречения

744

18,61

4. Да - конструкции

96

2,44

5. Незавършени и непълни синтактични конструкция

Подробен анализ и синтактично описание, отнасящо се към тези наблюдения, се намират в първата глава и също така във втората глава на тази работа.

При това разглеждане на проблема изхождам от това, че и публицистичните заглавия, благодарение на тяхната информативно-комуникативна функция трябва да ce разглеждат като комуникативни единици, независимо чрез каква граматична структура се иредставнт. /русская lрамматика, 1981, т. 2, CTр. 129 и сл./

Заглавия на руската преса, носещи характер на изречение, са разгледани на части вече от Рогински /1966/.

С тези примери и забележки, отнасящи се до една специална група на заглавията, искам да приключа наблюденията в информативно-комуникативен план. Много е трудно да се разграничат и да се опишат поотделно функциите на публицистичното заглавие, защото са диалектично свързани. Отделното им разглеждане трябва предпазливо да се направи, но то е необходимо, за да се получи по-пълно описание не само в рамките на един език, но и в съпоставителен план./ницолова, 1983/. 


\section{2. 3. ПРИЗИВНАТА ФУНКЦИЯ НА ПУБЛИЦИСТИЧНИТЕ ЗАГЛАВИЯ}

За привличане на внимание на читателя много често се използуват въпросителните изречения, които дори могат да имат провокирвщ характер /например "Заварено лете ли е мебелната промипленост?" РД 24.01.84Г., "Уж бързаме, а стигаме бавно, защо?" РД 11.01.84Г./, те са обикновено по-близко до разговорната реч и се възприемат лесно от читателя.

Спецификата на публицистичното заглавие като въпрос предполага при читателя да провери своите знания, които ще обобщят и ще обогатяват съществуващите в съзнанието на читателя знания. Под форма на въпрос такава операция се налага на читателя. Самият отговор е само краят на тази операция, както е посочено и от Флайmер и Михел /1977/.

В публицистиката авторите се стремят въпросите да бъдат привлекателни и интересни, да предизвикат интереса на читателя към статията. Наблюдаваме често частни въпроси в заглавията съдържащи пълнозначни въпросителни думи. А отговорът се представя в статията, той не се знае предварително. Примери: "Какво стои зад сухия език на цифрите?" РД 14.12.83г., "Кому служи антисъветската реторика?" РД 04.11.83г., "Кой уби Реймонд Филипс?" РД 14.12.83г., "С кого наистина?" РД 02.12. $83 \Gamma .$, Кога и къде ще почиват учениците?" РД 14.12.83Г., "Горчиво или сладко?" РД 14.12.83г., "Кой е виновен за дългите опашки?" Рд 16.12.79г., "Модернизация или увеличаване на ядреняя арсенал?" РД 16.12.79г., Сигурност, но каква?" РД 17. 12.83г., "Какво добро си направил?" РД 13.12.79г.

Една по-подробна класификация на заглавията-въпроси е предложена при разглеждането на българските публицистични заглавия в първата глава на тази работа.

\section{ก. 2. 4. ПОДБУДИТЕЛНА ФУНКЦИЯ НА ПУБЛИЦИСТИЧНИТЕ ЗАГЛАВИЯ}

Чрез подбудителната функция на публицистичното заглавие се предизвиква не само определена реакция при читателя, а и се изразява закана към действие. Заглавието има и една оценъчна 
Функция, която води читателя от своя страна до определени изводи .

Авторът /журналистът/ чрез подбора на определени прилагателни, наречия или метафори, т.е. чрез стилистични похвати, изразява своето становище към събитието или ситуацията, наприmep: "Das Chile Pinochets ist eine Hölle der Gewalt" ND 29.01. 85, или "Sternenkriegsprogramm - neue stufe des Wettrüstens Demagogie Washingtons ist gefährliche Täuschung" ND 29.01.84,

или чрез прилагателни:

а/ положителни:

"Добри постижения" РД 24.01.84r.

"Плодотворни резултати" Рд $03.06 .85 \mathrm{r}$.

"Големи придобивки" Рд 25.05.85г.

6/ отрицателни:

"Варварски бомбардировки" Рд 01.01.84Г.

"Цинично изявление" РД 13.01 .84 Г.

"Възмутително и антихуманно явление" РД 25.05.85Г.

По този начин читателят получава една оценка на представената в статията ситуация или на събитие.

Публицистичните заглавия с изразена подбудителна Функция са един особено ценен журналистически похват на масовата агитация, когато се касае за едно по-пряко въздействие върху

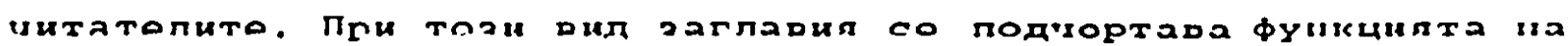
вестника, както е подчертано от Ленин /1959, стр. 690/ "като колективен пропагандист и колективен агитатор, но и сыцо така колективен организатор."

Като заглавия, които съдържат една пряка закана или подбуда към действие, трябва да се разглеждат в българския език не само самите подбудителни изречения от типа на "Не се лекувайте сами!" РД 16.11.79г. или "Спрете играта с ядрения огън!" Рд 16.12.83Г., но и да-Формите, които изразяват подбуда, напр.: "Да вземем повече от полето!" РД 12.06.85г. При последните примери се открива още една комензационна възможност за отпадналата инфинитивна форма. Попов /1973, стр. $114 /$ 
окачествява да-Формите като застъпник на стария инфинитив, Съцо така на някои причастни форми, те могат да изразяват и известна неопределеност на действието, близо до изразяваната чрез инфинитив, т.е. могат да съдържат и реално действие, изразявано чрез индикатив.

Но от Функционална гледна точка употребата на първоличната да-Форма в множествено число играе важна роля в публицистиката /подробно по този въпрос - в четвъртата глава на тази работа/. Чрез нея много ясно се изразява призивният и подбудителният характер на публицистичните заглавия. При разглеждането на този проблем демонстрирам сыествуващата конкуренция на императива с да-формите. Но журналистът с определено комуникативно намерение предпочита да-формата в 1 . лице множествено число пред императивната форма от 2 . лице множествено число, за да изрази с да-Формата приобщаване към множеството чнтателя, към които се отправя поканата, а не да се дистеанцира от тях, както е при императивните Форми. При това с да-формата за 1. лице множествено число пишещият се сближава с читателя. Неведнъж е подчертано, какво голямо значєние има първото лице множествено число за българската разговорна реч, напр. у Пашов /1978, стр. 445/.

Тъй като употребата на да-формите в публицистичните заглавия показва нарастваща тенденция, съм обърнала специално внимание върху тях и особено на превода на публицистичните заглавия с да-форми от български на немски. Необходимо е специално при тези форми да се разграничават граматичните от семантичните явления при изследването на един аналитичен език като български и един синтетичен език като немски. 
1. 0. СТРУКТУРЕН АНАЛИЗ НА БЪЛГАРСКИТЕ ПУБЛИЦИСТИЧНИ ЗАГЛАВИЯ

1. 1. ХАРАКТЕРНИ ОСОБЕНОСТИ И КЛАСИФИКАЦИЯ НА БЪЛГАРСКИТЕ ПУБЛИЦИСТИЧНИ ЗАГЛАВИЯ

Специфичните изрази и синтактични конструкция на публицистичния стил доказват съществуването на една диалектическа връзка между стила на писане и граматичните форми.

Обобщавайки възгледите на Fleischer и Michel /1977, стр. 41/, Riesel и Schendels /1975, стр.5/ и Брезински /1976, стр. 91/ приемам като дефиниция на понятието стил следната: "Стилът е съвкупност от всички индивидуално проявени осбености в творчеството на автора като едипство на характерното и частното на темата, идейното съдържание, художествения метод, жанровете на произведенията и средствата на езика. Стилът в този смисъл е сложно явление, той обхваща както съдържанието, така и формата."

Публицистичният стил, който съществува в съвременния български език като един Функционален стил, заедно с разговорния, научния, художествения и административния стил, е свойствен на периодичния печат, в който се разглеждат текущи общественополитически въпроси. Той се обуславя от обективната

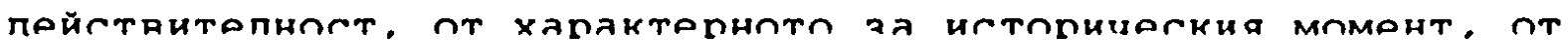
обществените отношения и естествено от журналиста, който пише в този стил. Характерно за публицистичния стил е, че се използуват думи и изрази, които имат емоцоионално въздействие върху читателя. Журналистите често ги използуват, защото чрез тях се повишава експресивността на езика, психологическата обрисовка се задълбочава и емоционалният ефект на такива заглавия става по-увлекателно и по-интересно за читателя.

това положение в немската публицистика е аналогично. Публицистичните текстове са кратки, ясни, стегнати и лесно се възприемат от читателя. Особено заглавията се отличават със своята максимално кратка, стегната и сбита фор- 
Ma.

1. Така например в заглавията с тире често се наблюдава изпускането на глагола или на спомагателния глагол, които изпълняват функцията на сказуемо в изречението. Глаголите се "подразбират" от читателя. Например в заглавия като "Личният пример на комунистите - стимул за успехите" РД 09.01.84Г., Борбата за мир - най-важната задача" Рд 13.02.84г., "Предотвратяването на ядрената катастрофа - основната задача" РД 02.02.84г., "Агресията на IOAP срещу Ангола - следствие От империалистичната политика" Рд $08.01 .84 \Gamma$.

2. Една друга друга характерна особеност на публицистичните заглавия е неконкретизиране на лицето, на което се приписва признак. Посочва се само действие, състояние или статичен признак. Примери:

"Уверени в изпълнението на мисията" РД 18.01.84Г., "На приказки около самовара" РД 18.01.84Г., Единни в борбата за мир" Рд 05.01.84г., "За стриктното изпълнение на поетите задължения" РД 05.01.84Г.,"Твърда воля за мир", РД 20.01.84Г., Остро осъждане на експанзията" РД 09.01.84Г.

Както показват примерите, заглавията са написани в една по-кратка, по-икономична форма от изречението - в сло восъчетание. Какво е словосъчетание? С какво се характеризира тази синтактична конструкция в нашите граматики? ДеФиницинте на словосъчетанието в българската и в немската граматика по смисъл и по различаване на словосъчетанието от из речението съвпадат.

Като дефиниция на синтактичната конструкция словосъчетание приемам тази на Попов /1974, стр. 30/: "Словосъчетанието е съединение най-малко на две самостойни, пълнозначни думи, които образуват смислово и граматическо единство. Изречението е основна граматически и интонационно завършена единица на речта, а словосъчетанието е част от из речението, негов строителен материал. Изречението има характерна за него завършена интонация. В известни случаи словосъчетанието придобива завършеност на интонацията и може да 
стане изречение." За целите на журналистиката и нейният стил Брезински /1976, стр. 39/ обяснява словосъчетанието по следния начин: "Словосъчетанието е граматически организирано съединение на пълнозначни думи /т.е. в словосъчетанието не се включват предлозите, съюзите, частиците, междуметията/. За разлика от изречението словосъчетанието не е Функционална, а само структурна единица, т.е. строителен материал за поголеми цялости, каквито са изреченията, абзаците и пр.".

1. 1. 1. СТРУКТУРНА КЛАСИФИКАЦИЯ НА БЪЛГАРСКИТЕ И НЕМСКИТЕ ПУБЛИЦИСТИЧНИ ЗАГЛАВИЯ

Българските словосъчетания се класифицират по следния начин, според ГСБКЕ/1983 том 3, стр. 27 и сл./:

Устойчеви /Фразелогически/ словосъчетания

6

Съчинителни словосъчетание

Имении сло- Глаголни восъчетасловосъния четания
Свободни словосъчетания

Подчинителни словосъчетания

$$
\begin{aligned}
& \text { Прилагател- } \\
& \text { но-именни } \\
& \text { словосъче- } \\
& \text { тания }
\end{aligned}
$$$$
\text { Наречни слово- }
$$$$
\text { съчетания }
$$

B

/Характер на елементите според връзката им в словосъчетанието/ 


\begin{tabular}{|c|c|c|c|c|c|}
\hline чpes cr- & 4pe3 & чрез при- & чрез & чpe 3 & $x_{\text {чрез }}$ \\
\hline гласува- & пред- & лагане & Съюз & слово- & рекция \\
\hline
\end{tabular}

X - Тук трябва да се обърне внимание върху факта, че рекцията в съвременния български език, например при глаголи и местонмения има вече лексикален характер, това е ясен признак на неговия аналитичен характер, както е подчертано в ГСБКЕ /1983, том II, стр. $35 /$ и От Попов /1978, cтp. $340 /$. 
Схема за класификацията на словосъчетанията в немската граматика според Jung /1982, стр. 139/ и Атанасова-Сугарева /1983, crp. $174 /$.

A

Устойчеви /Фразео-

Свободни словосъчелогически/ словотания

съчетания

正

Съченителни словосъчетания /koordinierende Wortgruppen/ Подчинителни словосъчетания /subordinierende wortgruppen/

Имения сло-

Глаголни

Прилагател-

Наречни словосьчетания словосъчени СлОвОСъвосьчетатания четания

ния

P

/Характер на връзката между елементите на словосъчетанието/

$\begin{array}{lcllll}\text { чрез съ- } & \text { чрез уп- } & \text { чрез } & \text { чрез } & \text { чрез } & \text { чрез } \\ \text { гласува- } & \text { равление } & \text { предлог } & \text { прила- } & \text { съюз } & \text { слово- } \\ \text { не } & \text { /рекция/ } & & \text { гане } & & \text { реда }\end{array}$


Както се вижда от схемите едно сравнение между немските и българските словосъчетания, въпреки различния характер на разгледаните езици, е възможно. Освен научното становище, че словосъчетанието е номинативно езиково средство и че то е строителен материал на изречението, съществува и друго мнение, според което подлсгът и сказуемото образуват един вид словосъчетание. Това мнение се изгражда върху факта, че между подлог и сказуемо съществува вид синтактична връзка, наподобяваща връзка между звената в словосъчетанието.

Обаче това мнение не взема под внимание, че връзката между подлога и сказуемото се различава качествено от другите синтактични връзки, защото това отнотение е едно цялостно отношение, което може да изгради едно изречение и образува една "съобщителна единица". Това мнение не определя правилно спецификата на изречението.

изречението е една цялостна единица на речта, която се отличава с предикативна връзка от словосъчетанието и има собствена интонация.

Във връзка със словосъчетанието трябва да се спрем и на теорията за синтагмата. Синтагмата не всякога съвпада С границите на словосъчетанието. Понятието синтагма е въведено от $\Phi$. де Сюсюр в езикознанието и означава съчетание от два елемента, свързани с подчинителна връзка. Според съветските автори, звената на изречението, които са отделени с паузи, се наричат синтагми. Една точна. дефиниция на понятието синтагма дава Виноградов /1950/ по следния начин: Синтагмата е семантико-синтактична единица на речта, отразяваща "късче действителност", изпълнена с живата експресия и интонация на дадено събитие. Синтагмата може да се състои от една дума или от цяло изречение в зависимост от целта на изказването, от експресивно-смисловата организация на речта и от словореда на семантико-граматическите единства. Синтагмата е свързана с контекста, има семантико-стилистичен характер, докато словосъчета- 
нието най-често представя една разширена част на изречението. В по-новите граматики синтагмата ce дефинира като интонационно оформена смислово-синтактична единица на речта, съставена от една или няколко думи, които в даден контекст изразяват просто или сложно понятие.

изследването на синтагматичните семантични връзки се извършва чрез семантичния синтаксис /Лоренц, Войтяк 1977/. Синтагмата се изследва и от лексикологична гледна точка, тъй като в семантиката на думата /отделните лексеми/ лежат основните предпоставки за свързването на отделните лексеми в по-големи семантични единици като изречения или текст.

Тъй като предметът на тази работа са публицистичните заглавия, които нито са абзаци, нито са текстове, ще употребявам термина словосъчетание, който най-добре окачествява преобладаващия дял на синтактичните конструкция на публицистичните заглавия. А заглавията, които са изречения се разглеждат разбира се като такива в граматико-семантично отнотение.

A понятието синтаксема има лексикална насоченост и не $е$ подходящо за този план, в които разглеждам публицистичните заглавия като синтактични единици, затова употребявам термина "словосъчетание", както вече е посочено в увода.

Както установих вече, публицистичните заглавия предстарлльат по сролта струщтура чссто олорооччстани. Cога що направя един подробен анализ на тези заглавия, конто представляват именни словосъчетания, предложно-именни словосъчетания и ще видим в какви варианти те ce срещат като публицистично заглавие.

1. 1. 2. ПУБЛИЦИСТИЧНИ ЗАГЛАВИЯ, КОИТО СА ПО ФОРМА БЕЗПРЕДЛОЖНО-ИМЕННИ СЛОВОСЪЧЕТАНИЯ

Най-голямата Фреквентност от всички именни словосъчетания се наблюдава при тези словосъчетания, които се състоят от 
прнлагателно име + съществително име. Те са най-кратката, най-концентрираната форма за окачествяване, квалифициране и преценка на лице, предмет или събитие.

a/ Описание /квалификация/ на лице: Примери: "Популярен художник" РД 10.01.1984, "Скромният шампион" РД 09.01.1984, "Безупречният контрольор" РД 13.01 .1984$.

б/ Характеризира се действие, събитие или предмет: Примери: "Агресивни приготовления" РД 13.01.1984, "Недопустима дейност" РД 13.01.1984, "Братско сътрудничество" Рд 18.01.1984,"Варварски бомбардировки" РД 08.01.1984, "Рядко Събитие" НМ 08.01.1984,"нови платове" РД 07.01.1984, "Висококачествен цимент" РД 06.01.1984, "Опасни автовлакове" РД 04.01.1984, "Дълбоки корени" РД 15.01.1984, "Интересна колекция" РД 11.01.1984, "Космически гамаизточници" РД 04.01 .1984 .

Наблюдаваме също форми, при които две прилагателни имена характеризират едно съществително име. Примери: "НОви поливни площи" РД 26.01.1984, "Съветска юбилейна монета", "Перспективен нацоинален курорт" РД 20.01,1984, "Богата социална програма" Рд 20.01.1984.

в/ Към групата на безпредложните именни словосъчетания спадат и тези, които се състоят от числително +/прилагателно име/ + съществително име.

Примери: "10-хилядната матина" Рд 20.01.1984, "Първото поръчение" РД 11.01.1984, "Два големи таланта" РД 08.01.1984, "Пет български пиеси" РД 08.01.1984.

г/ Публицистични заглавия, които по Форма са местоимении словосъчетания:

При този вид заглавия наблюдаваме както в българските, така и в немските заглавия атрибутивна употреба на местоимението, срв.: членувани: "нашата гордост" нм 28. 06.1979, "Моята равна ..." РД 13.01.1984, "нашият насрещен план" НМ 29.12.1979, "Вашите въпроси - нашите отговори" НМ 07.12.1979, "Нашата демокрация" РД 24.02.1984.

Употребата на местоимении словосъчетания цели едно по-пряко обръщение към читателя от страна на автора. Чрез 
формата на 1 л. мн. ч. журналистът се присъединява към читателя. Употребата на местоименията е сполучлив похват за привличане на вниманието от страна на читателя, тъй като семантичното им съдържание е по-богато /срв. Велева, 1983/.

Прави впечатление при този вид заглавия, че преобладаващият брой от тях се употребява в членувана Форма,докато в немския език една такава употреба /Artikel + Pronomen + Substantiv/ е изключена, както показват и примерите във втората глава.

1. 2. 0. ПУБЛИЦИСТИЧНИ ЗАГЛАВИЯ, КОИТО СА ПО ФОРМА ПРЕДЛОЖНО-ИМЕННИ СЛОВОСЪЧЕТАНИЯ

Предлозите играят изключително важна роля в съвременния български език. Предлозите са неизменяеми думи, които изразяват синтактичните отношения на зависимост между членовете на изречението или словосъчетанието, Т.е. отношенията между съществителни, местоимения или числителни и техните определения, между глаголи, наречия или прилагателни и техните допълнения. Обединяващ признак на различните видове предлози, независимо от конкретното и абстрактното в тяхното значение, е Функиията им да изразяват отнотения в реалния свят. Паралелно с обогатяването на системата от

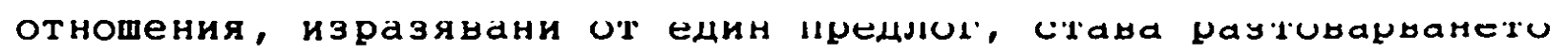
му от конкретните значения. Този прочес на постепенно загубване на конкретното, лексикалното значение на предлозите на сметка на развитието и обогатяването на абстрактните им значения се нарича десемантизация. Но колкото е по-висока степента на десемтизация на един предлог, толкова по-удобен изразител става той на каквото било отнотение./Граматика на съвр. бълг. език, том II, стр. 415/. Първоначалното значение на почти всеки предлог е било пространственото. При пространственото значение на предлозите се различават две разновидности: статично, при глаголи, които изразяват покой, състояние/ напр.: "Вече се прилагат впрактиката" РД 06.01.1984, "Конференцията в Стокхолм започна работа" РД 
18.01.1984, / и Финално - при глаголи за движение, направление /напр.: "Председателят на министерския съвет заминава за Виетнам, Кампучия и Лаос" Рд 15.01.1984/.

Българският език в развоя си от синтетизъм към аналитизъм, още в ранния среднобългарски период /XII-XIII в./ при съществуваща падежна система е започнал да пренебрегва противопоставянето покой-направление. Това явление е обща особеност на балканските езици. Загубата на формалното разграничаване между покой и посока довежда до установяване на финална и статична употреба при всички предлози с пространствено значение единствено в българския и в противоположност с другите славянски езици. Тези наблюдения се отнасят към глаголни сдовосъчетания, обаче техният брой в публицистичните заглавия е по-малко. Предложно-именни словосъчетания там се срещат повече. Но и в предложно-именните словосъчетания предлозите са полифункционални и десемантизирани. общото значение на предлога е така сложно, че може да бъде напълно разкрито само чрез подробното описание на всички негови частни значения.

Сега ще характеризираме значението и употребата на предлозите в публицистичните заглавия.

Предлогът без:

Предлогът без няма пространствени значения. Във всичките му употреби се проявява основното му значение за отсъствие.

В публицистичните заглавия предлогът "без" се среща в приименна употреба, изразяваш състоянието на отсъствие или недостиг. Срв.: "Земеделие безпочва" Рд 11.01 .1984$, "Без бащин дом" РД 22.01.1984, "на старини без бели коси", РД 03.01.1984, "Немислимо без знания" РД 06.02.1984, "Почти без съпротива" Рд 06.02.1984.

Предлогът в:

Предлогът"в"е основен предлог с пространствено значение. В абстрактните му значения се усеща винаги първона- 
чалното му конкретно пространствено значение.

Както в художествената литература, така и в публицистиката, предлогът"в"притежава различни отсенки на своята семантика.

\section{1. Пространствени заначения:}

a/ Място, в чиито предели се намира или извършва нещо. Примери: "Растения в епруветка" Рд 11.01.1984, "В ръцете на работниците и майсторите" РД 06.02.1984, "Изключителна борба в мъгла и сняг" РД 06.02.1984, "Спасители в планината" РД 01.02.1984 "Паметна акция в центъра на София" РД 11.01. 1984, "Сърни в завода" РД 09.01.1984, "Реорганизация в армията" РД 30.01.1984, "Страхова психоза в белия дом" РД 30.01. 1984, "настъпление в морските дълбини" РД 20.01.1984.

6/ Характерно е за заглавията, че се посочва конкретна държава или град, в чиито предели се извърпва или се очаква нещо, предлогът "в" не се използува с конкретното му пространствено значение: Примери: "Среща в Москва" Рд 08.01 . 1984, "Пресконференция в Лагос" РД 06.01.1984, "Митинг в Пном Пен" РД 11.01.1984, "Нищо ново От срещата в Брюксел" РД 11.01.1984, "Предстощи разисквания в Стокхолм" РД 12.01. 1984, "на посещение в Лондон" РД 16.01.1984, "Стачка в ЮАР" РД 22.01.1984, "След изборите в Камерун" Рд 16.01. 1984, "Българската профсъюзна делегация в СФРЮ" РД 11.01.

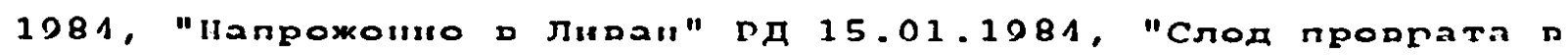
Нигерия" РД 11.01.1984, Тези заглавия съдържат съвсем точна информация за събитиего.

в/ Заглавия, конто изразяват преносни пространствени значения и отнотения чрез предлога "в". Те означават една област, в която се намира нещо или към което е насочено глаголното действие, означено с абстрактни съществителни /например на-ние, -не, -ост/ или такива съществителни, конто само в преносен смисъл могат да означават място. Понякога самият глагол или необичайното свързване на съществителните определя преносния характер на предложното съчетание: "Жив в народната памет" РД 20.01.1984, "Различия в общата стратегия" РД 17.01.1984, "Размах в инициятивите, 
в делата" Рд 06.02.1984, "Сътрудничество в химическата промишденост" РД 10.02.1984, "Интензификацията в центъра на вниманието" РД 15.01.1984, "Радост в мирния живот" РД 01.01. 1984, "Избори в сянката на кризата" РД 11.01.1984.

Не само при този вид заглавия би могло да се отделят случаите, когато предлогът, тук предлогът "в", свързва опосредствувано съществително с другите елементи на словосъчетанието, както това се наблюдава в примерите като:' Интензификация в центъра на вниманието" Рд 15.01.1984, "Медицината отново в центъра на програмата "Интеркосмос" РД 10.02.1984, "Сътрудничество в името на вековната дружба" РД 14.01 .1984$.

\section{Предлогът до}

Основното значение на предлога "до" в съвременния български език е предел, граница по отношение на място, време, мярка, състояние. Предложно-именни словосъчетания или изречения, съдържащи предлога "до" наблюдаваме по-рядко. Срв.:

a/ Пространствени значения: Предел на мястото, където достига действието: "Стигат ли пипалата на цРУ до ирландия?" Рд 16.01 .1984 .

6/ Граница при означаване на изходната точка на отрязък от пространството, разстояние. В съчетание с предлог "от", напр.: "Живи мостове от волга до Рила" Рд 26.01.1984, "От "Беореш" до мотел Правец - за 10 минути" РД 06.02.1984,

в/Близост: "До всеки дом" РД 10.02.1984

r/ Често значението на предлога се дапълва и подсилва От наречието близо: "По-близо до работниците" РД 17.01.1984",

д/ Преносни пространствени значения: Тези значения на предлога "до" се определят от по-високата абстрактност на думите, пред които стои предлогът: "Сътрудничество "от идеята до метала" Рд 13.01.1984, "Кратък ли е пътят до челното място?" РД 24.01.1984,

е/ Граница на период от време: "Неизвестни до края" Рд 10.01 .1984 .

\section{Предлогът за}


В съвременния български език предлогът "за" е на второ място по разнообразие и богатство на Функциите си и по честота на употребата си след предлога "на". Същевременно това енай-силно измененият български предлог, който напълно е загубил изходното си значение - направление назад или следване на някого или нещо във финални конструкции, а в статично - разположение в задната страна на нещо, като се е превърнал в основен предлог за изразяване на финално-целни и причинни отнотения. В съвременния български език и специално в публицистичните заглавия предлогът "за" е изразител на следните типове отнотения:

1. Период от време, през което се върши действието: "От "Бебреш" до мотел "Правец" за 10 минути" Рд 06.02.1984, a/ Пореден път на извършване на действието: "За първи път жена!" Рд 10.02.1984.

2. Най-често в публицистичните заглавия предлогът "за" изразява предназначение. Това са именни словосъчетания, в конто второто съществително след предлога "за" показва за какво служи обектът, назован с първото:

"Суровини за полската металургия" РД 10.01.1984, "топлина и грижи за "третата" възраст" Рд 26.01.1984, "Два милиона рубли за мемориалния комплекс" РД 18.01.1984, "Средствата за информация в служба на мира и сътрудничество-

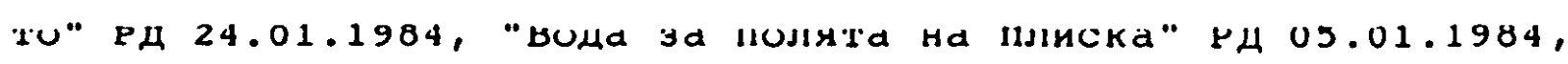
"Програма за зедена вълна" РД 16.01.1984.

3. наблюдаваме в публицистичните заглавия свързване на предлога "за" с определени девербативни имена, напр.:

"Улеснения за клиентите" Рд 09.01.1984/глаг. улеснявам/, "Подготовка за целите" Рд 18.01 .1984 /глаг. подготвям / ce/, "Опити за дестабилизация" Рд 10.02 .1984 /глаг.опитвам /се/, "Признание за българската философия" РД 19.01.1984, /От глаг. признавам/,"Борба за мир и комунизъм" РД 06.01. 1984, /глаг. боря се/, "Грижи за работниците" Рд 13.01.1984, /Глаг. грижа се/, "Чест за българския народ" Рд 05.01.1984 /глаг. чествувам/.

4. Както предлогът "за", така и предлогът "заради" 
може да изразява в чия полза се върии действието, напр.:

"Заради спокойните дни и нощи" РД 20.01.1984.

В заглавията не са засвидетелствувани всички значения на предлога "заради".

Предлогът "зад", който е нов по образуване е изразител на старото пространствено значение на предлога "за". Този предлог се среща само единично в заглавията на публицистичните материали: "Голямата тояга зад маслиненото клонче" Рд 14.01 .1984

\section{Предлогът из}

Основното старо значение на предлога "из" е отделяне, отдалечаване от вътрешността на нещо, движение от вътре навън. Това значение на предлога "из" обаче твърде рано е било стеснено от основния предлог с изходно значение "от". В публицистичните заглавия предлогът "из" почти не се среща, само единични примери откриваме:"Из анкетните карти" РД 13.01 .1984 .

\section{Предлогът като}

Предлогът "като" по произход е наречие, но се употребява съмо като съюз. Основната функция на предлога "като" е да изразява сравнение. В публицистичните заглавия често липсва субектът на сравнение, което е направено с цел да възбуди интереса на читателя. Примери: "Като зимна приказка" РД 29.01.1984, "Като добри стопани" РД 02.02.1984, "Като земята ..." РД 07.03 .1984 .

Предлогът към
Предлогът "към" е един от основните предлози в старобългарския език. В съвременния български език той чувствително ограничил вече своите финални функции.

Изразява се:

1. Пространствено отношение - посока: "Към сибирските реки" РД 13.01.1984, "Към близките и далечните пространства на вселената" РД 01.01.1984, "Случаен лъч към върха на айс- 
берга" РД 03.01.1984, "Врати към света" РД 02.02.1984.

2. Отношение спрямо някого: "Почит към Яворов" РД 10. 01.1984, "Последна почит към изтъкнатия борец" РД 14.02.1984, "Доверие към най-достойните" РД 30.01 .1984 , "Изисквания към всички" РД 07.03 .1984 .

3. Отношение спрямо нещо: "Интерес към книгата" РД 08. 01.1984, "Редовно пренебрежение към критиките" РД 06.02.1984, "Стремеж към трайно присъствие" Рд 10.02.1984.

Предлогът между

Предлогът "между" произхожда от съществителното "межда", а и пространствените отношения са близки до конкретното значение на това съществително. В заглавията този предлог се среща единично.

1. Положение между два или повече предмета: "Живот между верига и куршум" Рд 17.01.1984, "Живот между куршумите" РД 12.02 .1984 .

2. Отношение между две или повече лица: "Съревнование между братя" РД 14.01.1984, "неизравнено единство между партия и народ" Рд 07.03.1984.

\section{Предлогът на}

Преллогит "на" Р най-често употрекяваният Ћилгаргки предлог, тъй като е натоварен с най-многобройни и най-абстрактни значения. Той е също най-често срещнатият предлог в публицистичните заглавия.

Превръщането на предлога "на" в чисто граматично средство за изразяване на стари падежни отношения - косвено дателно допълнение на глагола и аналитично предаване на притежателно отношение - е най-важният критерий за определяне на хронологичната граница между двата основни периода в развоя на българския език - синтетизма и аналитизма. Същевременно установяването на предлога "на" при дателно допълнение и при притежателни конструкции е най-отличителната черта на българския аналитизъм. 
1. Отнотение на принадлежност, притежаване:

"Апетитите на Пентагона" РД 18.02.1984, "Западната врата на Москва" РД 10.01.1984, "Новото правителство на нигерия" РД 19.01.1984, "Столицата на Мадагаскар" РД 24.01.1984, "Фирмен магазин на "Сердика" Рд 17.01.1984, "Успехи на миньорите" РД 12.01.1984, "Дела на комунистите" РД 18.01.1984, "Капризите на зимата" РД 24.01 .1984$.

2. Често в заглавията са посоченеи собствени имена на политици или други дейци и личности на обществено-политическия живот, информира се за тяхната дейност:

"Среща на другаря Тодор Живков с другаря Жорж Хауи" РД 05.01.1984, "Среща на А. А. Громико с Дж. Шули" РД 19.01.1984, "Реч на Другаря Константин Черненко" РД 14.02.1984, "Декларация на председателя на ОАЕ" РД 14.01.1984, "Обиколката на Роберт Хоук" РД 30.01.1984, "Декларация на Х. ІЈмит" РД 14.01. 1984, "Решение на X. Кол" РД 02.02.1984, "Изявление на Ван Ли" РД 16.02.1984, "Поредният рекорд на Дювалие" РД 16.02 . 1984 .

3. Пространствени отношения:

Място, в чиито предели се проявява дадено действие: "Закусвални на открито или ... " РД 15.02.1984, "На друг континент" РД 15.01 .1984 .

\section{Предлогът над}

Предлогът "над" е характерен пространствен предлог, който във финална, и в статична употребе е противоположен на значението на предлога "под". Подлогът "над" означава място по-горе от нещо, където е насочено или извършено действие.

В заглавията откриваме предлога "над" повече в сратична употреба: "Електроенергия над графика" РД 12.01.1984, "над графиците" Рд 11.01.1984, "Силни бури над Северна Европа" РД 15.01.1984.

\section{Предлогът от}

Предлогът "От" е основният /и почти единствен/ предлог в съвременния български език, който изразява отнотение 
за отделяне. Първоначалната функция на предлога в старобългарския език е отдалечаване на изходната точка на едно движение. От това конкретно пространствено значение се развива изразяването на началната точка на всяко друго действие, на изходност, на отделяне въобще.

В публицистичните заглавия предлогът "от" изразява:

1. Изходност: "Вода от извора" Рд 22.01.1984

2. Отдалечаване: "Без дистанция От проблемите" РД 18.01. 1984.

3. начален предел във времето: "От зората на кинематографията" Рд 13.01.1984.

4. Партитивност /Отделяне на част от цяло/: "Страници от натата нацоинална история" РД 08.01.1984, "Нов том от Събрани съчинениея на В. И. Ленин" Рд 11.01 .1984$.

5. Производители на действието: "Жалба от адвокатите на Антонов" РД 17.01.1984, "Дарение от художници" РД 04.01.1984,

6. Местопроизход: "Машини От СССР" РЛ 05.01.1984, "Гости От близки и далечни страни" РД 03.01.1984, "Туристи от квартала" РД 26.01.1984, "Новини от столичния зоопарк" РД 24.01.1984, "Сигнали От невидимата действителност" РД 24.01.1984, "П.тнически влак От БАН" РД 21.01.1984, "От борда на самолета" РД 21. 01. 1984, "Сувенири от фирмения влак "Албена" Рд 24.01.1984, "Факт От репортерския бележник" РД 09.01.1984. Специално при

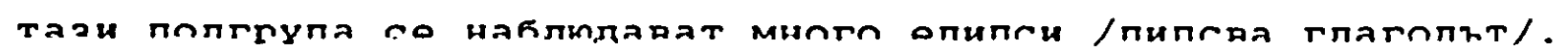

7. Твърде близко до значението за произход и материя е изразяването на определения чрез предлога "от",качеството на определяемия обект се разкрива чрез съставните му части:

"Нови асортименти От птиче месо" РД 05.01.1984, "Ползата от коланите" РД 11.01.1984, "Реката от светлината, културата и още нещо" Рд 11.01.1984, "Комедия от доводи" Рд 02.02 . 1984 .

8. Източник за получаване на нещо: /полза, изгода, печалба или източник на сведения/ "Добри резултати от всеотдайната и упорита работа на трудещите се през миналата година" РД 17.01 .1984 .

Заглавията с предлога "от" показват много разнообразна 
семантика.

Предлогът по

Предлогът "по" е стар предлог с основно пространствено значение. Днес той изразява пространствени, темпорални и множество абстрактни отношения.

Изразяване на:

1. Пространствени отношения: "Българската художествена култүра по света" РД 20.01.1984, "Услуги по месторабота" Рд 05.01.1984, "Българската архитектура по света" Рд 26.01.1984.

2. Посока на действието: /Действието има същата посока или следва нещо/: "Твърдо и уверено по изпитания курс Рд 16.02.1984, "По следите на нашата критика" РД 06.01.1984, "Киното по пътя на прогреса" РД 22.01.1984, "По следите на крадците" РД 18.01.1984, "По маршрутите на братството" РД 03.01 .1984 .

3. Основание, съответствие /по = според/: "По стара тратиция" РД 17.01.1984, "По законите на интернационализма" РД 14.01.1984, "По повод публикуваното" РД 15.02.1984.

4. Предлогът "по" сочи областта на някаква дейност: "Бригадни съвети по качество" Рд 18.01.1984, "Разговори по кипърския въпрос" РД 11.01.1984, "Разговори по широк кръг въпроси" РД 11.01.1984, "Опит по химия".

\section{Предлогът под}

Предлогът "под" в публицистичните заглавия не изразява традиционната му натовареност като пространствен предлог. той се използува в преносен смисъл за посочване на "мястото", където се извършва или е насочено действието, изяснява обстоятелствата.

"Под закрила на ЦРУ" РД 11.01.1984, "Под чужд ритъм" РД 26.01.1984, "Под ръководството на комсомолците" РД 06.02 . 1984 ,

В публицистичните заглавия той ce наблюдава по-рядко. Предлогът "пред" 
Предлогът "пред" в публицистичните заглавия изразява следните отношения:

1. Място от гледна точка на лицето: "Отговорни задачи пред младежите" Рд 12.01.1984.

2. Предходност по време: "пред изгрев" РД 13.01 .1984$.

3. По отношение на кого или що /непряк обект/ ce проявява някакво качество, чувство или се извършва някакво действие: "Поклон пред саможертвата" РД 22.01.1984, Поклон пред подвига" РД 16.01.1984,"Дълбок поклон пред голямото съзидателно дело и светлата памет на Урий Андропов" Рд 12.02.1984,

\section{Предлогът през}

Предлогът "през" изразява:

1. Пространствено отношение: "През завоите или по найпрекия път?" РД 17.01.1984, "През три океана" Рд 13.01.1984.

2. Темпорални отношения: "Икономиката през януари" РД 02.02.1984, "През зимните дни" РД 07.01.1984, СОФийски адреси прз 1984" РД 17.01.1984, "Унгарската промишленост през 1984 година" РД 20.01.1984, "на почивка през ваканцията" РД 03.01 .1984 .

\section{Предлогът при}

Предлогът "при" се среща по-рядко. Той е основен пред-

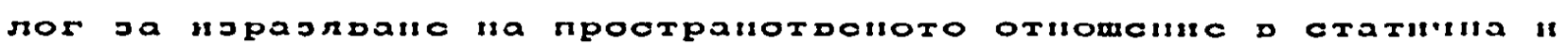
финална употреба.

1. Непосредствена близост: Младост при белите бобини" РД 11.01 .1984 .

2. Обстоятелства, придружаващи действието: "научен подход при подбора на търговските работници" Рд 10.01.1984, "Строителство при нула градуса" Рд 11.01.1984, При висок интерес" РД 11.01.1984.

\section{Предлогът с}

В съвременния български език предлогът "с" е изразител главно на социативни отношения /съвместност, придружаване, взаимност/. Характерно за неговия исторически развой е, че 
той напълно се е освободил от старобългарските пространствени отнотения за отдалечаване, изходност, които днес са преминали върху предлога "от". Паралелно с това предлогът "с" така е развил социативните си Функции, че във всяка днешна негова употреба се чувствува оттенък на съвместност, на придружаване.

1. Социативни отношения: Взаимодействие, действието се извършва в еднакви отношения спрямо друг, напр.: "Икономическа помощ с политически условия" РД 09.01.1984.

Социативни отношения, конто приписват свойство и качество на предмета: "Дейност с високи цели" РД 22.01.1984, "Теория с гарантирано качество" РД 06.02.1984, "Компания С важно значение" РД 11.01.1984.

2. Средство, оръдие на действие: В тази функция предлогът "с" заедно с името след него е заместник на стар творителен падеж, напр.: "Политика с боксови ръкавици" РД 02.01. 1984

3. Снабденост: "Еленът с червената лента" РД 15.01. 1984, "Всеки със свой принос" РД 16.01.1984, "Българските сортове с български имена" РД 16.01.1984.

4. Обектни отношения: "Вечери с творчеството на яворов" Рд 13.01.1984, "Среща с академичната фотография" РД 26.01.1984, "Среща с поезията на Евтушенко" РД 06.02.1984, "злополука с самолет" Рд 12.01.1984, "Диалози с трудовите хора" РД 10.01 .1984 .

5. Характерни за публицистичните заглавия са такива елиптични заглавия с предлога "c", които съдържат едно съществително име, срв.: "С комунистическа убеденост" Рд 26. 01.1984, "С младежки ентузиазъм" РД 09.01.1984, "С отлично качество" РД 20.02.1984, "С ускорени темпове" РД 26.01.1984.

Публицистични заглавия, конто са предложно-именни словосъчетания с предлога "след", се срещат само единично:

Предлогът след

Предлогът "след" изразява темпорална последователност или непрекъснатост /темпорална и локална/. Срв.: "След по- 
бедата" Рд 15.02.1984, "Град след град" Рд 24.01.1984.

\section{Предлогът сред}

Предлогът "сред" се среща в публицистични заглавия, изразяващ пространствено значение, близо до конкретното значение на съществителното "среда", от което той произлиза. Този предлог обаче рядко се среща.

Примери: "Метеоролози сред ледовете" Рд 12.01.1984, "Сред трудовите колективи" Рд 06.01.1984.

\section{Предлогът срещу}

Предлогът "срещу" запазва във всички свон употребн отсянка от конкретното си първоначално значение - противоположно движение или положение спрямо предмета. В публицистичните заглавия "срещу" изразява най-често противопоставяне, враждебно отнотение, вземане на мерки спрямо някого или нещо.

Примери: "Обвинителен акт срешу Рейгеновата политика" РД 20.01.1984,"Възмущение срещу насилието" РД 12.01.1984, "Провокации срещу Никарагуа" РД 14.01.1984, "Срещу ядрения шантаж" РД 20.01.1984, "Протест срешу намесата" РД 02.02.1984, ""Успешни действия срещу агресора" Рд 11.01.1984, "Борба с всички сили срещу ядрената заплаха" РД 14.01.1984, "Мерки срещу напаленията" РД 07.01.1984, "Агресивните действия срещу никарагуа пречат на нормалния изоорен процес" нц 00.02 . 1984 .

С тези примери приключвам наблюденията върху публицистичните заглавия, които по граматическата си структура представляват предложно-именни словосъчетания. Пак ще отбележим, че не се употребяват вснчки предлози на съвременния български език в публицистичните заглавия и че в заглавията не се изчерпва цялата семантика на предлозите.

1. 1. 4. ПУБЛИЦИСТИЧНИ ЗАГЛАВИЯ, КОИТО ПРЕДСТАВЛЯВАТ СЪОБЩИТЕЛНИ ИЗРЕЧЕНИЯ

Изречения, с които говорещият/тук пишещият/ осведом- 
ява слушателя/тук читателя/ за неизвестни нему /по предложение на пишещия/ Факти, се наричат съобщителни. Съобщителните изречения се използуват не само за пряко предаване, но и за запазване на информацията, получена в различните клонове на човешкото знание, на културата и изкуствата, както и на информацията, необходима за всекидневния живот на обществото. От всички видове изречения, различаващи се по комуникативната си Функция, съобщителните изречения имат най-широка употреба. Тезаемат голямо място в устната реч, и във всички писмени стилове на книжовния език - научен, художествен, публицистичен, администиративен /ГСБКЕ, том II, 1983, стр.47/. По строеж съобщителните изречения биват твърде разнообразни - пълни и елиптични, глаголни и безглаголни.

Напр,: /членувани/: "Информацията" РД 24.01.1984, Майсторът" РД 06.01.1984, "Равнището" РД 24.01.1984, "Животът" РД 22.01.1984, "Ветераните" РД 22.01.1984,"Земята" РД 15.01. 1984 .

Нечленувани: "Неспокойствие" РД 02.01.1984, "Силуети" РД 18.01.1984, "Израстване" РД 06.01.1984, "наставници" РД 20.01.1984, "Очертания" РД 01.01.1984.

Повелителното наклонение в заглавията на публицистичните материали не се открива, т. нар. повествователен императив наблюдава се само единично /вършителят на действието е говорещият, пишещият или трето лице/. Напр.: "Огледай се и виж къде си" РД 19.01.1984.

Характерно за глаголните съобщителни изречения $e$, че при обективен словоред подлогът преджожда сказуемото, срв.: "Необявената война продължава" РД 11.01.1984, "Патриотите предлагат реалистично решение" Рд 20.01.1984, "Промишлената естетика търси своя път" Рд 30.01 .1984 , "Тя ни храни, радва и вдъхновява" РД 30.01.1984, "Всички залагат на сигурността" РД 22.01.1984, "научните контакти подобряват взаимното разбирателство" РД 18.01.1984 "нР България признава държавата Бруней" РД 20.01.1984, "САщ предпочитат военно решение на проблемите" РД 11.01.1984, "Ръчният труд намалява" РД 10.02. 
84, при субективен словоред сказуемото може да преджожда подлога /срв. със словореда на другите видове изречения - въпросителни, подбудителни и т.н./ напр.: "Обсъждат се важни въпроси" РД 16.02.1984, "Осъжда се агресията" РД 07.01.1984, "Увеличават се изделията с оченка "К" РД 09.01.1984, "Разчита се на алпий ците" РД 17.01.1984, "Разтирява се търговската мрежа" РД 13.01.1984, "Гордея се с България" РД 21.01.1984, "Разиграва се поредния Фарс" РД 11.01.1984, "Възражда се mовинизмът" Рд 12.02.1984, Подготвят се избори" Рд 10.02.1984. Относно пунктоацията трябва да се отбележи, че в края на публицистичните заглавия не се пише никакъв препинателен знак. Съобщителните изречения представляват 12,448 от заглавията.

\section{1. 5. ВЪПРОСИТЕЛНИТЕ ИЗРЕЧЕНИЯ В ПУБЛИЦИСТИКАТА}

Изречения, с които говорещият/Пишещият/ посочва на слушателя/читателя/ непълноти в своята информация като желае информацията му да бъде попълнена чрез отговор, се наричат въпросителни. Въпросителните изречения играят важна роля в процеса на общуване, тъй като спомагат да се обменя именно необходимата, а не излишна информация между говорителя и слушателя. Важна е ролята на въпросителните изречения и в прочеса на човешкото познание изобщо, тъй като осъзнатото несъзнание, формулирано в определен въпрос, е първата стъпка към знанието/ГСБКЕ, том III, 1983, стр. 49/. В публицистичните заглавия често се употребяват "провокиращи въпроси", за ла се насочи вниманието на читателя повече към статията с такова заглавие, напр.: "Заварено дете ли е мебелната промишленост?" РД 20.02.1984.

При формално-семантичната класификация на въпросителните изречения на публицистичния материал се откриват следните групи:

1. Въпросителни изречения с въпросителна лума. Тези изречения са три вида:

a/ Въпросителни изречения с частици /наблюдавани са 
засега в публицистичните заглавия само въпросителни изречения с частицита "ли"/. По строеж въпросителните изречения с частица биват два вида:

1. Единични въпроси, чйито отговор представлява положителна или отрицателна форма на едно и също изречение, напр.: "Идва ли времето за първия медал?" РД 22.01.1984, "Умеем ли да почиваме?" РД 09.01.1984, "Розови ли са очилата на оптимизма?" РД 08.01.1984, За папки ли е създаденото?" РД 06.01. 1984, "Обективна ли е системата на атестиране?" РД 06.02.1984.

2. Разделителни /дисюнктивни/ въпроси: Тук е невъзможен само отговор "да - не", тъй като от такъв отговор не става ясно коя от предложените възможности се приема или отрича. Напр.: "Отпаднал или изключен?" РД 10.01.1984, "Истинско име или псевдоним?" РД 15.01.1984, "Отделен случай или нещо повече?" РД 05.01 .1984$.

б/ Въпросителни изречения с пълнозначни въпросителни думи: Пълнозначни въпросителни думи са въпросителните местоимения и наречия: кой, какво, кога, колко, къде, що и др. За разлика от въпросителните изречения с частици въпросителните изречения с пълнозначна дума не изискват отговор "да - не", а отговор, в който вместо въпросителната дума трябва да се употреби друга дума или изречение. Напр.: "Какви проблеми трябва да бъдат решени в нашето овощарство, за да бъде на световно равнише?" РД 20.01.1984, "Какво още е нужно за една приятна и полезна почивка?" РД 17.01.1984, "От какво е недоволен Герт Бастиан?" Рд 12.02.1984, "Къде е дирята на подвига?" РД 15.01.1984, "Докога ще се опрощават реалните загуби?", "Кога зимата не плаши?" РД 26.01.1984, "Защо не понскахте думата?" РД 05.01.1984, "Защо продължава вносът на машинни масла?" РД 09.01.1984, "Защо толкова симпатия?" РД 24.01.1984, "Какво не достига?" РД 18.01.1984.

в/ Въпросителни изречения С пълнозначни въпросителни думи и С въпростиелна частица срещаме само единично като публицистично заглавие. Напр.: "Къде ли е пределът?" РЛ 12.02 . 1984.

Въпросителни изречения наблюдаваме в 3,2 прочента от 
заглавията.

1. 1. 6. ПОДБУДИТЕЛНИ ИЗРЕЧЕНИЯ КАТО ПУБЛИЦИСТИЧНИ ЗАГЛАВия

Подбудителни се наричат изречения, с които говорещият подтиква към действие, респ. към прекратяване на действие на дадено действие.

В комуникативен план подбудителните изречения се различават според силата на волеизявата, която се определя също от социолингвистични фактори /например в публицистиката преобладава официално отношение между пишещия и читателя/.

Подбудителните изречения се различават и според евентуалния вършител на субективно необходимо действие. В този случай вършителя е читателя, множество читатели или множество читатели, в което влиза читателя. Наблюдаваме в публицистичните заглавия два вида подбудителни изречения - глаголни и безглаголни /ГСБКЕ, том III, 1983, стр. $68 /$.

а/ Примери за глаголни подбудителни изречения:

"Влизай, без да чукаш!" Рд 13.01.1984, "Пом показваш гордост, покажи и майсторство!" Рд 20.02.1984, "Не както можеш, а както трябва!" РД 08.01.1984. А във второ лице множествено число наблюдаваме следните примери: "Елате в планината!" РД 03.01. 1984, "Запознайте се: Илюшин!" РД 06.02.1984, "Пролетарии от

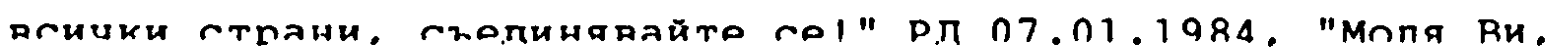
cпрете!" РД 06.01.1984.

Пряко обръщение към определено лице се среша само единично, напр.: "нужни са дела, г-н президент!" Рд 18.01.1984, б/ Безглалаолните подбудителни изречения в публицистичните материали са много разнообразни. Употребяват се много наречия и словоредът често е субективен, с цел да се засили подбудата:

"Винаги пълен напред!" РД 07.01.1984, "Ритмично - всеки ден, всеки час" РД 30.01 .1984$.

Наблюдаваме и възклицателни изречения при публицистичните заглавия, които съдържат подбуда. Примери: "Какъв хубав 
ден!" РД 08.01.1984, "Отново опасно лекарство!" РД 30.01.1984, "Към най-високото - Към Ботев!" РД 06.01.1984, "Тенденция покачване" РД 18.01.1984, "Предсрочно!" РД 30.01.1984.

В глаголните да-конструкции често наблюдаваме подбудителен характер. Затова ги разглеждаме като подбудителни изречения .

Глаголните да-форми заслужават голям интерес в съвременния български език, те са много интересно явление и ще обърнем специално внимание върху тях в онази глава на работата, която е посветена на съпоставката и проблемите на превода. С глаголни да-форми за сегашно време в съобщителните изречения може да се предаде и предполагаемо, въображаемо действие, например:

"Да направим света сигурен!" РД 29.01.1984, "Да запазим земята!" РД 14.01.1984, "Да се подобрят нормативните документи!" РД 20.02.1984, "Да идват младите и да останат!" РД 13. 02.1984, "Да се разговаря и за подхода!" Рд 05.01.1984, "Да знаем, къде сме!" РД 30.01.1984, "Да се чувствуваш горд" РД 10.02.1984, "В стремежа да се утвърждава новото" Рд 06.01. 1984 .

Такива изречения се наблюдават в 2,44 прочента.

\section{1. 7. ЖЕЛАТЕЛНИ ИЗРЕЧЕНИЯ}

Желателни се наричат изречения, С които говорещият само изказва пожелание за извършване на действие, тъй като става дума за такива процеси или такива вършители, на които говорещият/пишещият/ не може да въздействува в момента на речта или изобщо. В публицистикатажелателни изречения се наблюдават рядко, само в единични случаи, когато предстои едно определено събитие или например една нова година. Напр.: "Добре дотла 1984! Бъди мирна и честита!" РД 01.01.1984, "Сурва, сурва година - да е мирна и честита!" РД 01.01.1984, "Да бъде плодородна! ..." РД 01.01.1984, "Сурва, сурва година - да е весела, честита!" РД 01.01.1984, "Да е спорна, плодпносна!" РД 01.01.1984, "на добър час, алпинисти!" РД 21.02.1984, "Здравей, наша четвърта младост!" РД 10.02.1984. 
1. 1. 8. НЕЗАВЪРШЕНИ И НЕПЪЛНИ СИНТАКТИЧНИ КОНСТРУКІИИ В ПУБЛИЦИСТИЧНИТЕ ЗАГЛАВИЯ

В публицистичните заглавия срещаме и незавършени синтактични конструкции, става дума за тези с многоточие.

Tе са израз на такова взаимопроникване на синтактичните единици, което повишава експресивността на езика, задълбочава психологическата обрисовка и усилва емоционалния ефект на синтактичните средства /ГСБКЕ, том III, 1983, стр. $112 /$.

Различаваме няколко вида при тези синтактични конструкции :

1. Повтарят се изрази /тук съществителни имена/ с цел да се изразява, че те са многобройни. Примери: "Години, Години ..." РД 13.01.1984, "Класации, класации ..." РД 02.01.1984.

Често се употребяват конструкции с многоточие за да се постигне един определен психологически ефект, да се възбуди интересът на читателя. Двете части на конструкцията представляват едно семантично несъответствие, тяхната съпоставка изненадва читателя, конструкцията завършва след многоточитето неочаквано от семантична гледна точка в комуникативен план. Срв.: "Строителство в ... облаците" РД 20.01.1984, /стронтелството обикновено се извърщва на земна почва/, "Сгради от ... ламарина" Рд 12.01.1984, /сгради се строят обикновено от бетон/, "Производители на ... здраве" Рд 30.01.1984, /от производството обикновено излизат материални продукти/ "Спасение чрез ... самоизмама" РД 12.02.1984, / общоизвестно е, че самоизмамата не спасява нищо/.

Непременно трябва да посочим, че има заглавия с многоточие, които изразяват незавършеност на мисълта и на изречението. Очаква са от читателя, че статията ще допълни информацията. Например: "Да се събаря е лесно..." РД 04.01.1984, /възниква въпросът: А какво е трудно? или подобни въпроси/, "Ако до Вас падне метеорит ..." РД 17.01.1984, /очаква се нареждане, какво да са прави в такъв случай/, "за Перловската река и ..." Рд 18.01.1984/пита се: И какво оше?/.

С тези наблюдения приключваме разглеждането на заглавията с многоточие и ще обърнем внимание върху една друга гру- 
па на публицистичните заглавия - заглавия с тире. Ние ги наблюдаваме в 5,33 процента. Те са разнообразии и журналистите и употребяват с целта да се засилят признаците на интензивност. Когато се характеризира синтактичната цялост на конструкции с тире, откриваме диалогично единство в тях. От семантична гледна точка двете части могат да бъдат тъждествени. Срв.: "Опазване на природата - опазване на човека" РД 18.01. 1984, "Интензификация и качество - основна политическа задача" РД 26.01.1984, "Стопанският туризъм и отдих - важен отрасъл на нашето обществено развитие" РД 29.01.1984, "интенсификация и качество - сърцевина на партийната работа" РД 19. 01.1984, "Предотваряне на ядрената катастрофа - основна задача" РД 02.02.1984, "Активната жизнена позиция - характерна черта на младото поколение" РД 22.01.1984, "Изложба на нови висококачествени изделия от химическата промишленост - творческа среща на производители и потребители" РД 09.01.1984, Примери за семантично нетъждествени части на заглавия с тире:"Ремонтът - лошокачествен, а "процентните удари" големи" РД 09.01.1984, "В Тихия океан - 4000 ракети "Томахок" РД 03.01.1984, "Миграцията - непознат термин за село Плате" Рд 10.02.1984, "Лондон - зона без апартейд" Рд 11.01.1984. От синтактична гледна точка често наблюдаваме, че подлогът на тези непълни синтактични конструкции се изразява най-напред, а след тирето второстепенните части на синтактичната конструкция като обясняват или изясняват подлога. Тирето при тази група заглавия замества най-често глагола. Срв.: "Балканите - безядрена зона" Рд 12.01.1984, "Планът - предсрочно" РД 03.01.1984, "Битовите услуги - обща грижа" РД 17. 01.1984 , "Човекът - централната Фигура" РД 20.02.1984, "Първата десетдневка - предсрочно" РД 11.01.1984, "Личният пример на комуниста - стимул за успеха" РД 09.01.1984.

Такива заглавия изразяват информацията в по-стегнат вид, вместо пълно изречение, тъй като тирето пдчертава изпускането на второстепенните части на изречението, бихме могли да си представим такива конструкции като "скелет на информацията" без излишни обяснения. 
1. 2. изводи

Резултатите от тези наблюдения се онагледяват чрез следната таблица. Най-напред ще представя количествен анализ: Количествения анализ е направен на процентуалните изчисления върху 4000 български публицистични заглавия, които служат като основен материал на тази разработка. Те са фиксирани и систематизирани според посочените групи и подгрупи. По този начин се получава по-лесно онагледяване на съотношенията между отделните синтактични конструкции, които се срещат.

В българските публицистични заглавия са застъпени следните граматични конструкции:

\begin{tabular}{|c|c|c|c|}
\hline p & Вид & БPOด & ПРОIЦEHT \\
\hline 1 . & $\begin{array}{l}\text { Безпредложно именни словосъче- } \\
\text { тания }\end{array}$ & 892 & 22,23 \\
\hline 2 . & Предложно-именни словосъчетания & 1890 & 47,28 \\
\hline 3. & Изречения & 744 & 18,61 \\
\hline 4 . & Да-конструкции & 96 & 2,44 \\
\hline 5 . & $\begin{array}{l}\text { Незавършени и непълни синтак- } \\
\text { тични конструкции }\end{array}$ & 378 & 9.44 \\
\hline & Всичко & 4000 & 100,00 \\
\hline
\end{tabular}

Сега ще разгледаме всяка група поотделно с оглед на подгрупите: 1. Безпредложно-именните словосъчетания наолидаваме в публицистичните заглавия в следните форми:

\begin{tabular}{|c|c|c|c|}
\hline$p$ & Вид & БPOA & ПРОЦЕНТ \\
\hline 1.1. & $\begin{array}{l}\text { Местоимение + /прилагателно }+ \\
\text { съществително име }\end{array}$ & 42 & 4,70 \\
\hline 1.2 & $\begin{array}{l}\text { Прилагателно име + съществи- } \\
\text { телно име }\end{array}$ & 814 & 91,26 \\
\hline 1.3. & $\begin{array}{l}\text { Числително име + съществител- } \\
\text { но име }\end{array}$ & 36 & 4,04 \\
\hline & Всичко & 892 & 100,00 \\
\hline
\end{tabular}


При безпредложно-именните словосъчетания формата прилагателно име + съществително име е най-широко употребена. Тя лесно се усвоява от читателя. Словосъчетанието при безпредложните именни групи е съкратено до минимум.

2. Предложно-именни словосъчетания

Предложно-именните словосъчетания са най-широко разпространени в българските публицистични заглавия. Това отразява аналитичния характер на съвременния български език, който се характеризира с употребата на новите предлози и отпадналата падежна система. В публицистичните заглавия не се използуват всички предлози, в наблюдаваните примери предлозите вместо /и наместо/, въпреки /и пряко/, о/и около/, освен, свръх, подир, подире, спрямо и у не се срещат. Причината е вероятно, че някои от тези предлози са остарели вече, а в публицистичните заглавия се използуват само съвременните/т.е. по-новите/ предлози.

\begin{tabular}{|c|c|c|c|c|}
\hline ! 2 & Предложно- & -именни словосъчетания & 5POA & ПPOIЕHT \\
\hline 1 . & с предлог & "без" & 15 & 0,80 \\
\hline 2 . & с предлог & "B" & 384 & 20,43 \\
\hline 3. & с предлог & "до" & 15 & 0,80 \\
\hline 4. & с предлог & "3a" & 310 & 16,43 \\
\hline 5 . & с предлог & "и $3 "$ & 3 & 0,15 \\
\hline 6. & с предлог & "КъM" & 48 & 2,57 \\
\hline 7 . & с предлог & "между" & 9 & 0,46 \\
\hline 8. & с предлог & "на" & 643 & 34,15 \\
\hline 9. & с предлог & "над" & 9 & 0,46 \\
\hline 10 & с предлог & " OT" & 85 & 4,50 \\
\hline 11. & с предлог & "nо" & 46 & 2,41 \\
\hline 12. & с предлог & "пред" & 42 & 2,24 \\
\hline 13. & с предлог & "под" & 9 & 0,46 \\
\hline 14. & с предлог & "през" & 27 & 1,44 \\
\hline 15. & с предлог & "при" & 12 & 0,64 \\
\hline 16. & с предлог & "c" & 168 & 8,90 \\
\hline 17. & с предлог & "след" & 9 & 0,46 \\
\hline 18. & с предлог & "сред" & 11 & 0,60 \\
\hline
\end{tabular}




19. С предлог "чрез"
20. С предлог "срещу"
Всичко

Тази таблица показва кои предлози се употребяват най-много в публицистичните заглавия. Но този количествен анализ не изразява дали се изчерпват всички семантични възможности на посочените в таблицата предлози. Ориентираме се според ГСБКЕ, том II, стр. 416 и сл. В посочените значения на отделните предлози.

При предложно-именни словосъчетания с предлог "без" срещаме приименната употреба на предлога, а в публицистичните заглавия не срешаме второто му значение, да изразява липса на някаква част от цяло или недостиг.

Предложно-именните словосъчетания с предлог "в" наблюдаваме често. Предлогът "в" е много натоварен предлог в съвременния български език. Основните му значения са добре изразени в заглавията /пространствено, изразяване на преносно-пространствени отношения, описание на състояние и др./. В публицистичните заглавия не се засвидетелствуват и значенията на предлога "в" да изразява темпорални отношения, модални съчетания или да описва вида или цвета на предмети или облекла.

Другите значения на този функционален предлог срещаме често в публицистиката, те са посочени в тази глава подробно.

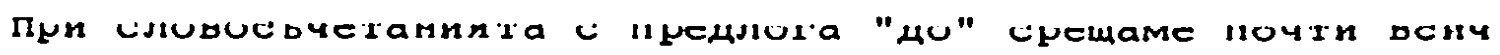
ки възможни начини за изразяване чрез този предлог, само Форми, които се използуват при обръщение или адресиране, както в писмата например, не срещаме в заглавията/например едно заглавие, което ще гласи "Молба до декана" е малко невероятно/. Но всичките други отношения /изразяване на предел, граница по отношение на място, време, мярка и състояние/ се срещат в заглавията. Както е посочено вече, предлогът "за" е на второ място по разнообразие и богатство на функциите си и по фреквентност на употребата си след предлога "на". Обаче, в публицистичните заглавия, за разлика от художествената литература предлогът "за" ce среща по-рядко. Не се изчерпват всичките му семантични възможности, наблюдаваме го във функцията си да изразява гростран- 
ствени отнотения, пернод от време, пореден път на действие, най-често изразява предназначение. Специално в публицистичните заглавия виждаме много добре, с какви девербативни имена се свързва предлогът "за". Не са засвидетелствувани неговите значения за изразяване на отношения за цел. причина, размяна и стойност, размяна на един предмет с друг предмет, полза и изгода.

Предлогът "зад" наблюдаваме само единично в заглавията за изразяване на пространствено отношение/място откъм гърба на някого или нещо/, непосредствена близост при движение като второто му пространствено значение не установяваме в материалите.

Предлогът "из"/предлозите низ, иззад, изпод и измежду въобще не се срещат в заглавията/ е от рядко срещаните предлози. Неговите значения за изразяване на разпръснатото положение, движение без определена посока или движението по продължение на нещо не се наблюдават в направените изследвания.

Предлогът "като" е полифункционален, употребява се като съюз и като предлог, но по произход е наречие. В публицистиката той се употребява в основната функция да изразява сравнението, наблюдаваме, че в заглавията понякога липсва субектът на сравнението, което има определена цел да възбуди интеpeca на читателя. В заглавията не срещаме неговата Функция да служи за уточняване.

Предлозите "край", "покрай", "накрай" и "кръз" за сега не ce срещат в материалите.

Предлогът "към" в изследваните заглавия не се появява във Функциите си да изразява целта на действието, приблизителност по време или количество или да посочи нещо, което се прибавя или принадлежи към нещо.

Предлогът "между" се явява единично в материала, неговите две Функции се изчерпват в тях.

Предлогът "на" е най-натовареният предлог в съвременния български език и в публицистичните заглавия. Обаче целите му отнотения и възможности не се употребяват в публицистичните заглавия. Не го наблюдаваме в следните функции: да 
изразява ценни отношения, причина, предназначение, съвместност с действието, отношения за количество, отношение за начин и преходни състояния.

Интересно при употребата на предлога "на" е да се види отношението субект - обект в отделните словосъчетания, специално в съчетание със съществителните имена за изразяване на косвено допълнение.

Предлогът "над" се открива в заглавията в статична употреба, другите му значения /преносни/ не наблюдаваме засега в матерналите.

Предлогът "от" /отвъд, отсам, оттам и оттатък не се cpemaт/ се употребява често и в много функции. не се засвидетелствувани неговите Функции за: изразяване на аблативни отношения, причина, количество и преминаване от едно състояние в друго в публицистичните заглавия.

Предлогът "по" се употребява в четири от посочените в граматиката му шест функция. В заглавията на вестниците не го срещаме да изразява темпорални отнотения или начин на действие.

Предлогът "под" се среща само единично в материалите, неговите Функции не се изчерпват в заглавията/за изразяване на количество, граница, посочване на отличителен белег не се употребява в материалите, само за посочване на начин на дсйотио или оботоптолстра/.

Предлогът "пред" наблюдаваме в три от неговите седем посочени в граматиката Функция. Той не се среща в словосъчетания за изразяване на непосредствена близост по място, причина, предпочитания или за посочване в присъствието на него се върши действието.

Предлогът "през" е засвидетелствуван в двете си функция /за изразяване на пространствени и темпорални отношения/ в публицистичните заглавия.

При предлога "при" не установяваме примери, които посочват Функцията му да изразява положение във времето, той посочва в примерите непосредствена близост или придружаващи обстоятелства на действието. 
Предлогът "c" е един от по-тироко застъпените предлози в заглавията. Наблюдават се редица елиптични конструкции с този предлог. В изследванията не се намерени примери, в които той изразява Функцията си да посочи количествени отношения, съдържание или условия, които съпътствуват действието или начин на действието.

Предлогът "свръх" засега не се забелязва в заглавията. Предлогът "след" се наблидава доста рядко. Няма примери за глаголни словосъчетания с този предлог.

Заглавия с предлозите "според" и "спрямо" не са засвидетелствувани в материалите досега.

Предлогът "сред" /всред, насред и посред не се срещат/ означава в заглавията пространствено значение. За изразяване на темпорално значение не го срещаме.

Предлогът "срещу" /примери със спроти не се забелязани/ се употребява за изразяване на противоположно положение или отношение спрямо предмет, явление или събитие в публицистичните заглавия. Не са засвидетелствувани примери за употребата му да изразява сълоставяне, сравнение или замяна или темпорално отношение.

С тези резюмиращи наблюдения върху предложно-именните словосъчетания в българските публицистични заглавия се доказва каква важна роля играят те в съвременния български език. те са застъпени в почти петдесет процента от примерите/срв. и таблицата/. Безпредложно-именните словосъчетания като найкратките единици и изреченията като най-завършените единици в заглавията заемат всяка група около двадесет процента. С тези факти от изследванията ясно се подчертава аналитичния характер на съвременния български език и са насочени тенденции в неговото развитие. 
2. 0. СТРУКТУРЕН АНАЛИЗ НА НЕМСКИТЕ ПУБЛИІҢСТИЧНИ

\section{ЗАГЛАВИЯ}

\section{1. УВОДНИ БЕЛЕЖКИ КЬМ СТРУКТУРНАТА КЛАСИФИКАЦИЯ НА НЕМСКИТЕ ПУБЛИІИСТИЧНИ ЗАГЛАВИЯ}

Анализът на немските публицистични заглавия ни представя не само съвременното състояние на немската публицистиката, но и сочи граматични тенденции на развитие при оформянето на публицистичните заглавия на немските ежедневници.

Наблюденията, които се водят от 1979r. насам се концентрират Главно върху заглавията на водещия ежедневни на ГдР "Neues Deutschland" /централния орган на ГЕСП/ и в по-малка степен върху вестника "Junge Welt" /централния орган на СНM/. При разглеждането на граматичните особености на немските заглавия на вестници имаме в предвид тяхната специфична принадлежност към публицистичния стил, чийто особености предписват известни изисквания към заглавието.

Брезински /1976, стр. 91/ пише: "Характерно за публицистичния стил $e$, че се използуват думи и изрази, които имат емоционално въздействие върху читателя. Особено в такива материали като есето, художествения очерк, литературната скица, фейлетона, театрална и филмова критика и пр. Но все пак трябва да са подчертава, че тази емоционалност е по-слаба,

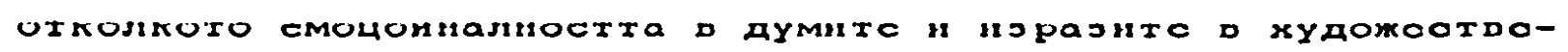
ната реч и най-вече в нейната поетична разнавидност. Емоционалността на публицистичните заглавия е обществена, а не лична."

Това мнение преобладава и в немската журналистическа стилистика, срв. Fleischer, Michel /1979/.

Специфичните особености на публицистичният стил наймного авторите виқдат в това, че в публицистичните материали наблюдаваме едно толкова тясно свързване, вплитане на отделните Функционални стилове/като се имат предвид всички материали, които влизат в съдържание на вестника/, че ние бихме могли да разграничим следните особености за описанието на публицистичния стил: 
- употреба на лесно разбираеми и бързо усвояваши се лексикални и синтактични изразни средства /включително на използуваните чужди думи, които трябва да бъдат разграничени до необходимия минимум, специални термини, названия на реалия, жаргонизми, неологизми, атрибутивни изрази и др./.

- сигнализация на най-важното от информацията и стимулация към четене чрез специфични журналистични похвати, например чрез интересно оформление на заглавието, представяне на информацията в най-сбита форма, езикова икономия, комбинирана с известна редундантност, подбор на изразни средства, които привличат вниманието на читателя.

- умерената и психологично правилната употреба на стереотипни изрази /идеологични ключови понятия, лозунги, клиширани изрази/. Тук можем да посочим мнението на Сольганик /1980/ по въпроса на употребата на "стандартизираните изрази" в публицистиката.

- Сольганик /1980/ като разсъждава за общите особености на публичистичната реч обръща внимание и на някои недостатъци в нея. На първо място "стандартизирането" на публицистичната реч, което е доста характерно за езика на вестника. Разбира се, стандартизацията изобщо на езика в по-голям или в по-малък обем е характерна за езика на вестника. Разбира се, ще открием стандартизацията на езика и в други сфери на езика, защото това е прогресивен и обективен процес, копто има за цел да създаде стегнати, комуникативно целесъобразни готови речеви форми, често доста стандартни, клиширани, шаблонни - сочи авторът - конто улесняват процеса на общуването. Тяхното отсъствие затруднява този процес, принуждава носителите на езика да създават обрати и конкретни изрази за всяка отделна ситуация, за всяко конкретно условие при общуването, а това вече засвидетелствува за недостатъчна разработеност на отделните жанрове. В такъв смисъл Сольганик до голяма степен рехабилитира толкова навикваните български и немски шаблонни изрази, които в дадени ситуации биха се оказали доста полезни.

Една известна стандартизачия бихме могли да открием и в 
художествената реч - твърди Сольганик. И публицистиката, и художествената литература се обрымат към масова аудитория, но вестникът се обръша към масите или към отделните социални Групировки, класи и т. н. като цяло. Художествената литература се обръща към конкретния читател, а чрез него към всички читатели. Индивидуализацията на стандартността на речта се постига чрез обновление и чрез изменение на шаблонните изрази и чрез умело варияране. Резюмиращо може да се каже, че общоезиковите тенденция към стандартизация и експресивност имат в публицистичния стил специфичен, своеобразен харктер.

- Актуализация на журналистичната информация чрез специфичното езиково офрмление, употреба на изразни средства, т.е. употреба на специфични стилистични похвати /перифрази, метафори и др./. Комбинацията от снимка и коментар в нея, специално обръщение към читателя и др. Тук можем да срещнем и елементи от разговорния стил, както твърди и Розенталь в неговите наблюдения. Розенталь /1980/ прави интересни изследвания върху синтаксиса на езика във вестника. Наблюденията му са точни, изводите следователно фундаментирани и приложими. Той твърди, че синтаксисът на публицистичната реч представлява съчетание от книжен и разговорен синтаксис. В процеса на демократизацията на литературния език се наблюдава

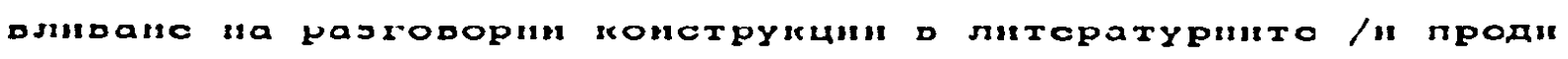
всичко в публицистичния стил/, а от друга страна, пироко разпространение добиват в разговорната реч конструкция, първоначално свойствени само на книжните стилове на речта. От книжните стилове - твърди Розенталь - синтаксисът на вестникът взанмствува присъщата на писмената реч нормативност, обработеност, а от разговорния стил заема форми и конструкции, конто са характерни за устната реч. Именно в това се крие основата за значителното влияние на разговорната реч върху езика на вестниците. Причините, които изброява Розенталь, са разнообразни:

1. Разговорната реч е най-масовата форма на обиуване.

2. Разговорната реч притежава такива несъмненни до- 
стойнства като краткост, лаконичност и пр., конто се обуславят не само от закона за икзномия за усилия, но и от пироко използуване на мимиката, жеста, от контекста или ситуацията. Съвкупно тези фактори подкрепят стегнатостта на формата, сбитото съдържание на фразата. Така се реализира общият за всички средства за масова информация и пропаганда лозунг "За единица време - максимум информация."

3. Разговорната реч става своебразен противовес на книжния език по вестникарските страници, тъй като вестникарският език отразява общите закономерности в развоя на съответния национален език.

2. 2. СТРУКТУРНА КЛАСИФИКАЦИЯ НА НЕМСКИТЕ ПУБПИІИСТИЧНИ ЗАГЛАВИЯ

При разглеждането на граматичната структура на немските публицистични заглавия ориентираме се главно според възгледите на Erben /1966/, Admoni /1970/, Heidolph, Flämiq, Motsch /1981/, Heckel /1972/, Helbig, Buscha /1979/, Riesel, Schendels /1975/, Fleischer /1983/.

Прави впечатление, че както в българската, така и в немската публицистика фреквентността на употребата на субстантивни словосъчетания /в това число влизат и безпредложните и предложно-именните словосъчетания/ е сравнително висока. Почти половината от всички разглеждани заглавия са субстантивни словосъчетания в най-различни варианти. Нека да ги разгледаме по-подробно сега:

2. 2. 1. Анализ на немски публицистични заглавия, които по Форма са безпредложно-именни словосъчетания

При тази група срещаме главно словосъчетания, състоящи се от прилагателно име + съществително име. Тези форми са най-кратките и най-концентрираните за квалификацията на лице, предмет или събитие:

а/ Квалификация на лице:

Neuer Ministerpräsident ND 30.05.1979 
Der neue Liebknecht JW 13.12.1979

Junge Mathematiker ND 3./4.2.1979

б/ Квалификация на предмет, явление или събитие:

Aktuelle Philatelie JW 10.08.1979, Schwedische Skizzen JW 17.08.1979, Sozialistische Länder JW 12.12.1979, Schweres Unwetter ND 24.05.1979, Kuriose welt JW 04.09.1979.

Наблюдаваме и примери с компаративна и суперлативна Форма на прилагателното, определящо съществителното : Effektivere Hartmetalle ND 11.04.1979 (Komparativ), Größter Windgenerator JW 10.08.1979 (Superlativ), Wärmster Augusttaq JW 16.08.1979 (Superlativ).

Прави впечатление извънредно честата употреба на сложни думи, както и на сложни съществителни:

Neue Zypernverhandlungen ND 12.12.1979, Schwerer Verkehrsunfall JW 06.09.1979, Mobile Schafschurstation ND 28.08 . 1985, Universelles Klebegerät ND 29.+3.1979, Neue Sammlerausweise ND 29.03.1979, Demokratische Rechtssprechung ND 18./ 19.02.1984, така и на сложни прилагателни:

Erdbebensicheres Produkt JW 13.12.1979, Erlebnisreiche Tage JW 03.09.1979, Eindrucksvolle Dokumentation JW 06.09.1979.

При тези придагателни наблюдаваме композиция от съществително + прилагателно. Срещаме и Форми, които се състоят от crumms upnsalaresin n csummn comeciontesmn naru:

Erfolgreiche Musikentwicklung ND 30.03.1979

$\mathrm{S}+\mathrm{A} S+\mathrm{S}$

Erfolgreiche Drogenfahndung ND 28.8.1985

$$
\mathrm{S}+\mathrm{A} \mathrm{S}+\mathrm{S}
$$

Fleischer /1983, стр. 240/ определя такива сложни думи като "масово явление не само в научния, но и в публицистичния стил, тъй като чрез тези изразни средства се дава на автора възможността, на минимум пространство да съобщи максимум инФормация."

Относно членуването на тези заглаваия се установява, че те се членуват с определен член само единично, малко по-често наблюдаваме форми с неопределен член, срв.: Eine alte Hand- 
werkskunst ND 30.03.1979, Ein reiches Kulturleben ND 11.04. 1979. Липсата на членът пред основната дума /определителен и неопределителен/ наблюдаваме дори там, където присъствува в говоримата реч, тогава примерите оше по-ярко ще покажат това явление .

Тези примери сочат, че най-често използуваните определителни елементи в безпредложните субстантивни словосъчетания са прилагателните имена. Но срещаме и многобройни съкращения във Функиията на определение, предимно в заглавия, които се състоят само от една дума и които по принцип няма да причислим към тази група, а към групата на "отделните думи", но тъй като тези съкращения служат като определения, искаме да ги представим тук. Прави впечатление, че съкращенията в българската преса се използуват по-малко, отколкото в немската. Примери като : RGW-Fotoausstellung ND 11.04.1979, SALT-Treffen JW 30.05.1979, DDR-Solidaritätssendung JW 06.09.1979, ce намират почти във всеки брой на периодичния печат, те се срещат и в другите групи на заглавията/напр. при предложно-именните групи и в изреченията/.

Към тази група на безпредложните имения словосъчетания спадат и онези заглавия, които се състоят от числително + съществително. Те се наблюдават по-рядко, напр.: с числителни бройни: 48 Millionen Ägypter ND 29.01.1985, 10 о00 Bodenproben ND 28.08.1985, 80 000 neue studenten JW 06.09.1979, 144 Drogentote ND $18 . / 19.02 .1985$

- с числителни редни: Die einmillionste Tonne JW 10.08 . 1979, 9. Treffen JW 05.09.1979, 3. Solidaritätskonzert JW 17. 10. 1979 .

Интересен е също Фактът, че в немските публиицистични заглавия отношението на принадлежност се изразява и чрез употребата на генитив без предлози. Тези форми не са рядкост, нanp.: Begrenzung des Wettrüstens JW 06.09.1979, Der Bewegungsdrang des Kindes JW 13.12.1979, Visitenkarte des Sports JW 13.12.1979, BeschluB der KPdSU ND 17.12.1979, Kernwaffentest der USA JW 10.08.1979, Parteitag der SP Chiles ND 28.8. 1985, Altmeister der Folk-Musik ND 04.02.1986, DDR-Sportler 
des Wettkampfjahres ' 85 ND 04.02 .1985 , Streiks der Gewerkschaft Öffentlicher Dienst ND 04./2.1985.

2. 2. 2. Немски публицистични заглавия, които са по форма прономинални словосъчетания

Този вид словосъчетания срещаме с лични местонмения във второ лице единствено число, напр.: Du und deine Zeit JW 10.08.1979, Du und das Buch JW 04.06.1979, и във второ лице множествено число: Unser Wohnungsbauprogramm JW 04.09.1979, Unser Interview JW 05.09.1979, Unsere Fragen JW 10.08.1979, Unser Mann in Parlament JW 12.12.1979.

те се употребяват главно с целта, авторът да се обърне пряко към интателя/чрез формата на второ лице ед. ч./ или журналистът да са присъедини към аудиторията на читателите. И в двете форми се получава едно по пряко отнотение към читателя, тъй като чрез тези лични местоимения винаги се постига един по-силен призивен ефект/за ролята на местоименията и тяхната Функция в различните стилове, виж велева 1983/. Картината на заглавията се разнообразява чрез такива форми и тези заглавия изпълняват функцията си да привличат интереса на читателите.

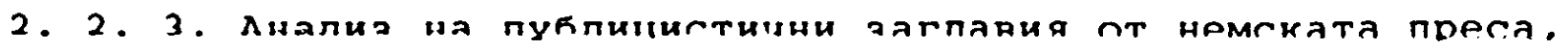
които са по Форма предложно-именни словосъчетания

Предложно-именни словосъчетания се наблюдават често в немската публицистика, затова е необходимо да се разглаеждат подробно тези форми. Тук няма да повтаряме общите положения, които са характерни за българските и за немските предлози, ще изтъкнем само някои особености в употребата на отделните предлози в публицистичните заглавия. Както в българския, така и в немския език един и същ предлог може да изразява различни отношения. Характерно за немските предлози е, че те определят падежа на думата, пред която стоят. Според тяхната рекция ние можем да ги делим според: 
- предлози с винителен падеж/Akkusativ/

- предлози с дателен падеж/Dativ/

- предлози с родителен падеж/Genitiv/

- предлози с винителен и дателен падеж.

При разглеждането на семантичната страна на предлозите ce ориентираме главно по Flämig/1981, стр. 697 в Heidolph, Flämig, Motsch 1981/. Както в българските, така и в немските публицистични заглавия далеч не се изчерпват всички потенциални възможности на семантичното съдържание на предлозите. Употребяват се само най-важните им значения.

Като изброяваме всички предлози в съвременния немски език, които са с Akkusativ: bis, durch, entlang, für gegen, ohne, um. wider, ще установим в наблюденията, че те не се срещат всички в публицистичните заглавия и съответно фреквентността на тяхната употреба не е една и съща при разглежданите предлози.

1. Публицистични заглавия с предлози с рекция на Akkusativ:

a/ предлог bis: среща се в заглавия като: Lieder und Gedichte bis kurz vor Mitternacht JW 18.09.1984, тук се изразява един краен момент на период от време /bis wann?/ другите значения на този предлог за означаване на граница, цел, край или точка на движение не се срещат в примерите, нито другите му значения за изразяване на "без изключение"/до/ или с изключение на, освен.

Предлогът durch: За предлогът "durch" обикновено в граматиките са посочени четири значения: 1. преместване пред дадено пространство или предмет, 2. средство, 3. причина, повод, 4. при трансформация на пасивни изречения в отглаголно съществително + родителен падеж, но това тук не е релевантно, защото разглеждаме сега предложно именни групи, изречения покъсно.

В публицистичните заглавия срещаме "durch" в две значения.

1. Изразяване на преминаване през дадено пространство, 
Hanp.: Höhlentripp durch den Sandstein JW 17.08.1979, Zu Fuß durch Nordthüringen JW 04.09.1979.

2. За посочване на причина, повод: Verstärkte Waldbrandgefahr durch hochsommerliche Hitze ND 06.06 .1979 , npaви впечатление честата употреба на сложни думи/. Todesopfer durch Unvorsichtigkeit JW 13.12.1979, 14 Tote durch Giftpilze JW 16.08.1979, Schwere Schäden durch "David" und "Ken" JW 05.09 .1979 .

В немските публицистични заглавия, които представляват предложно-именни словосъчетания един от най-често употребените предлози е предлогът "für". Той може да изрази:

1. Предназначения, 2. Заместване /вместо/, 3. Ред, последователност, 4. Промеждутък от време 5. Цена, количество. С тази сравнително висока семантична натовареност предлогът "für" ce наблюдава изключително само с първата семантична Функция в публицистичните заглавия. Той изразява главно предназначение:

Wasser für 34000 Hektar ND 28.08.1985, Schiff für ArktisGewässer ND 28.08.1985, Entwicklungshilfe für Nordost-China ND 18./19.02.1984, Spenden für Nikaragua JW 05.09.1979, Mobiles Hospital für Äthiopien ND 28.08.1979, Milde Urteile für Neonazis JW 10.08.1979, Rote Nelken für Ben Chavis JW 16.12.1979, Hohe Ehrung für Romesh Chandra ND 29.06.1979, Rüstungsmilliarden tur BKD-Luttwarte JW $13.12 . \mid y / y$, H1Lte rur Champuchea ND 28.08.1985, Forschung für den Frieden ND 18./ 19.02 .1984 .

Публицистични заглавия от тази група с предлога "gegen" изразяват главно отношение на съпротива, борба срещу някого или нещо, примерите в семантично отношение напомнят примерите с българския предлог "срещу". В съчетание с глаголи "gegen" изразява обикновено движение в известна посока, сравнение или се употребява за изразяване на приблизително време или количество /на български "около", "към"/.

В примерите на тези безглаголни заглавия този предлог изразява съпротива, борба:

a/ срещу някого: Entscheidungen gegen Sioux JW 13.12 . 
1979, Repressalien gegen Studenten in Chile JW 20.05.1979, Ausschreitungen der Polizei Südafrikas gegen Schulkinder ND 28.08.1985, Willkür gegen Ärzte ND 18./19.02.1984.

6/ cpemy нещо: Ansturm gegen Apartheid ND 28.08.1985, Aktionen gegen Politik Israels ND 06.06.1979, Protest gegen Pentagon-Pläne ND 29.03.1979, Proteste gegen die Hochrüstung JW 13.12.1979, Appell gegen die Diktatur JW 12.12.1979.

Предлогът "ohne" означава липса, среща се в тази група заглавия само единично, напр.: Erfurt ohne Chance ND 24. 05.1979, в глаголните словосъчетания и изречения топ̆ се среща по-често.

Чрез предлога "um" се изразява най-напред кръгообразно движение, напр.: Im Zeppelin um die Welt JW 10.08.1979, Quirliges Spiel um den tatendurstigen KOKORI 29.03.1979, и в преносен смисъл: Rund um den Wohnungsbau ND 04.09.1979. Наблюдава се и в публицистичните заглавия и за изразяване на отнотение към някого: Sorge um den "Grünen Freund" JW 16.08 . 1979, и за изразяване на темпорално отношение: Jeder Termin um einen Tag früher JW 30.05.1979. Не се срещат негови семантични функция за изразяване на разлика при мерки, числа, ред и последователност в тези заглавия.

2. Публицистични заглавия с предлози с рекция на Dativ:

В посочените граматики на немския език се изоброяват следните предлози с рекция на Dativ: aus, außer, bei, binnen, entgegen, gegenüber, gemäß, mit, nach, nächst, nebst, von, samt, seit, zu, zuwider.

Предлогът "aus", който означава изходна точка, произход, материя, от което е направено нещо, причина, основание период от време от по-далечното минало, срещаме в тези безглаголни словосъчетания главно за изразяване на произход на нещо, често се посочват конкретни географски названия, напр.: Rohstoffe aus dem Polarkreisgebiet JW 10.08.1979, Kinderzeichnungen aus Vietnam JW 10.08.1979, Bäuerliche Kunst aus Ungarn ND 06.06.1979, Mißliches aus den USA JW 12.12.1979, 
JW-Korrespondenz aus Leipzig JW 04.09 .1979 или с по-общи локални определения: Friedenslieder aus aller welt ND 18./19. 02.1984, Werte aus der Datenbank ND 06.06.1979, Die Retorte aus der eigenen Werkstatt ND 11.04.1979, Gewürze aus dem Garten ND 28.08 .1979$.

Другите функция на този предлог не се срещат в безглаголните словосъчетания.

Предлогът "bеi" означава:

1. Пространствена близост: Bandenterror bei Maputo ND $18 . / 19.02 .1984$.

2. Присъствие, може и пребиваване на лица, напр.: Leonid Breshnew bei Pionieren JW 10.08.1979, peter Schreier als Dirigent bei der 30. Mozartwoche ND 29.01.1985.

3. В публицистичните заглавия често се употребява "bei" за подчертаване на пряко присъствие при събитие: Bulgarischer Doppelerfolg bei EM-Kämpfen der Heber ND 24.05.1979, 17 Tote bei Admirals-Cup JW 17.08.1979, /преносно значение/ Bestechungen bei US-Wahlen ND 30.03.1979.

Предлогът "bеi" не се среща за означаване на време / през", "при"/ в този тип заглавия.

Предложно-именни словосъчетания с предлога "mit" ce срецат сравнително често като публицистични заглавия.

те означават:

1. Dudsra memuy sinua:

Treffen der Waffenbrüder mit Werktätigen und Soldaten ND 20. 03.1979, Treffen Leonid Brshnews mit Enrico Berlinguer JW 06. 09.1979, Freundschaftliches Gespräch mit Rumäniens Außenminister ND 30.03.1979, JW-Leserinterview mit Maxi Gnauck 12. 12.1979, Viele Begegnungen mit Moskauer Komsomolzen ND 03./ 04.02 .1979 .

2. Снабденост: Mischpult mit 12 Kanälen JW 01.08 .1979$, Dessauer Bibliothek mit Angebot für Brigaden ND 28.08.1985, Barkas mit Elektromotor ND 18./19.02.1984, Leichtbauplatten mit dekorativer Oberfläche ND 28.08 .1985 .

3. Средство, оръдие на действие: Mit Hubschraubern gegen Schädlinge JW 30.05.1979, Mit Kescher und Lupe JW 16.08 . 
1979.

4. Социативни отношения, които приписват свойство и качество на събития или явления:

Berliner Festtage mit zahlreichen Höhepunkten ND 28.08.1985, Kurzweilige Show mit lustigem Kinderzoo ND 28.08.1985, Schwedisches Orchester mit spanischem Feuer ND 06.06.1979.

немският предлог "mit" изпълнява функции като българският предлог "с".

Предлогът "nach" ce среща в публицистичните заглавия с следните Функции:

1. Посока на движение към някаква цел, срещаме тук географски имена, напр.: Beileidstelegramm nach Mauretanien JW 30.05.1979, Ex-Schah nach Panama JW 17.12.1979.

Тук служи българският предлог "за".

2. Време /кога?/ антоним на "vor"/ преди/ Neubeginn nach langer Pause JW 12.12.1979.

3. Обектни отнотения :

Suche nach $100 \mathrm{Kindern}$ JW 17.09.1979

Семантичните Функции на предлога "nach" да изразява последователност, съгласуваност или съответсвие не се срещат в безпредложно-именните заглавия.

Предлогът "von" в предложно-именните публицистични заглавия изразява няколко отнотения:

1. Най-много се изразяват авторство, причина или причинител: Herzliche Gratulation von Erich Honecker ND 14.02.1979.

2. Принадлежност: Erstes Foto von Halley ND 28.08.1979, FDJ-ler von Schwarze Pumpe mit hohen wettbewerbszielen ND 14. 04.1979 .

3. Качества, признаци, свойства на лица, предмети или абстрактни неща:

Eine Rohstoffquelle von großem Gewicht ND 06.06.1979.

Предлогът "von" може да изразява и изходна точка за време, но в тези безглаголни словосъчетания не го наблюдаваме в тази функция.

Предлогът "zu" означава:

1. Крайна точка/цел/ на едно движение: 
Fahrt zu den Frühlingwiesen ND 29.03.1979/wohin?/

2. Време /кога?/

Öfnungszeiten $z u$ Ostern ND 11.04.1979

3. Изразява отношение към нещо или някого:

Aktive Beziehungen $z u$ anserer Umwelt ND 06.06.1979, Gute Beziehungen zu Nachbarn JW 21.08.1979.

Във функция да изразява мярка, брой или цена предлогът не ce наблюдава в публицистичните заглавия от този тип и това е очаквано.

3. Анализ на публицистични заглавия, които са по форма предложно-именни словосъчетания с предлози, които имат рекция на Dativ и на Akkusativ

Предлозите с рекция на Dativ и Akkusativ в немския език ca следните: an, hinter, in, neben, auf, über, vor, unter, zwischen /10нг, 1982, стр. 353/. Те ca с рекция на Akkusativ при глаголи, които изразяват движение към определена цел /определено място. /Wohin?/ А когато тези предлози се употребяват при глаголи, които изразяват покой или движение на едно място /ненасоченост към определена цел/ те имат рекция на Dativ. /Wo?/ Тази особеност е от особено значение при " превода на тези примери от немски на български. В тази глава le pustremuar meminnte sarsaonn camo o rexen ctpyutypen " Функционален план, на превода е посветена четвъртата глава, където тези въпроси за рекцията на предлозите са разгледани подробно.

Тъй като рекцията на предлозите в изречението или в вербални словосъчетания зависи главно от глагола, в безглаголните предложно-именни словосъчетания глаголната рекция отпада и түк, например в публицистичните заглавия с предлога im, наблюдаваме само случаи, когато се определя място, значи рекцията на предлога im, /който е образуван от in + dem/ тук изисква Dativ:

Appell im Pionierpark JW 17.09.1979, Musik großer Meister im historischen Kloster ND 29.03.1979, Vielfältige Forschungen 
im Himmelslabor Salut - Sojus ND 11.04.1979, Brand im Erfurter Centrum-Warenhaus ND 28.06.1985, Zugunglück im Bezirk Magdeburg JW 03.09.1979.

Същото положение срещаме при предлога "in", който в тези безглаголни заглавия сочи мястото на едно конкретно събитие, касае се за точни географски названия на страни или градове. В тези заглавия ясно се демонстрира стремежа на максималното съкращение на съобщението, тъй като се посочва само събитието и мястото /какво, къде/, свързани чрез предлога "im" или "in". Българските примери на безпредложните словосъчетания с локални определения с предлога "в" са аналогични по отнотение на максималното съкращение на израза, техният превод не затруднява / виж в четвърта глава по въпросите на превода на тези заглавия/.

\section{Примери :}

Neofaschistischer Mord in Rom ND 30.03.1979, Verhandlungen in Genf ND 06.06.1979, Pressefeste in Wien JW 03.09.1979, Millionenraub in Paris ND 11.04.1979, Busunglück in Nordsimbabwe ND 29.01.1985, Raubserie in West-Berlin JW 13.12.1979, Feuerpause in Nordiran ND 29./3.1979, weiteres SALT-Treffen in Genf ND 24.05.1979.

Такива заглавия се срещат във всеки брой на вестниците, бихме могли да ги определеим като "номинален скелет" на информацията, без никакви цруги елементи /глагол, член и др./ Предлозите "in", "an", "von" изискват винаги дателен падеж, когато изразяват период или отношение на време. В публицистичните заглавия наблюдаваме "in" и "vor" в такава Функция, напр. :

Ruhig und gelassen in der startphase ND 11.04.1979, In einer Viertelstunde zwei Diebstähie ND 28.08.1985, Nigeria vor dem Wechsel JW 17.08.1979, Vor dem 40. Jahrestag der Befreiung ND 29.01.1985, Vor Operngastspielen in wien und Lausanne ND 11.04 .1979 .

Публицистичните заглавия, които представляват предложно-именни словосъчетания с предлога "auf" имат рекция на Dativ, когато изразяват едно статично положение или местно 
определение, срв.: Zirkus auf dem Eis JW 17.08.1979, spuren der Großväter auf dem Eis ND 18./19.02.1984, Goldpreis auf Rekordhöhe JW 05.09.1979, и рекция на Akkusativ, когато изразяват действие или отнопение към нещо или някого:

Ein Blick auf die Fischerinsel ND 06.06.1979, (Wohin?), Ein heiterer Blick auf Zeitgenossen ND 24.05.1979, Bombenanschlag auf sowjetische UNO-Mission JW 13.12.1979 (Auf wen?) Uberfall auf Mocambique ND 06.06.1979, Uberfall auf USABürger Jw 17.12.1979, Pirsch auf den Hirsch JW 06.09.1979.

Публицистичните заглавия от тази група с предлог "über" означават:

а/ пространствено отнотение: /над/ напр.: Sturm über Norditalien ND 28.08.1985, Museum über der Donau JW 17.08. 1979, Flüge über der Arktis ND 06.06.1979

6/ абстрактни отнопения /тук с рекцията на Akkusativ/: Gespräch über Zusammenarbeit ND 28.08.1985, Bündige Antworten über Bauern im Wohngebiet ND 29.01.1985, Abkommen über Arbeit der Kulturzentren JW 30.05.1979, Sammelband über Forschungsergebnis ND 29.01.1985, Mediziner-Tagung über Herz-Kreislaufleiden ND 29.01.1985, Erfahrungsaustausch über Lehrmethoden JW 17.08 .1979$.

в/ надхвърляне на границата: Uber Plan und Gegenplan hinaus ND 24.05.1979/TyK се засилва това значение чрез наречието "ninaus".

Немските публицистични заглавия от тази група с предлога "zwischen" означават отношение между държави, организации и др., този предлог има түк рекция на дателен падеж: Treffen zwischen staatschef der VDR Jemen und der JAR ND 29. 03.1979, Weitere Zusammenarbeit zwischen SED und UPDM JW 12 . 12.1979, Gespräche zwischen Sadat und Begin in Haifa JW 06 . 09.1979, Freundschaftstage zwischen Jugend Angolas und der DDR ND 11.04 .1979 .

Интересно е наблюдението, че предложно-именни словосъчетания с предлози с рекция на родителен падеж се срещат изключително рядко, единично. Това са предлозите: Jenseits, innerhalb, auBerhalb, oberhalb, unterhalb, kraft, längs laut, 
mittels, statt, anstatt, trotz, ungeachtet, unweit, vermöge, während, wegen, halber, um ... willen, zufolge, конто ce срещат много често в глаголните групи.

С тези наблюдения приключваме наблюденията върху немските публицистични заглавия, които представляват предложноименни словосъчетания. Тяхната група е сравнително голяма, честотата на тяхната употреба е висока/срв. таблицата в края на тази глава/.

Наблюденията показват, че най-често като определителни елементи в субстантивните словосъчетания се употребяват прилагателни имена и други съществителни или предложни групи. По-рядко се срещат като пояснителен елемент преиложението в субстантивното словосъчетание, напр.:

Benzin-Spargerät JW 01.08.1979, Gelegenheitsangler-Tips JW 17.08.1979, DDR-Solidaritätssendung ND 07.04.1979, Auftraggeber Arbeiterklasse ND 04.02.1986, Die Forderung Frieden ND 10.08 .1979 .

Този въпрос за приложението е тясно свързан с апозиционната синтагма. Нейната употреба посочва нарастваща тенденция в немския език, това е пак израз на номинализацията, рационализация и езикова икономия. Хакел /1972, стр. 341/ обяснява апозиционната синтагма по следния начин: "Това са онези субстантивни словосъчетания, при които най-малко две обикновено семантично съгласувани и намиращи се във взаимна детерминираност съшествителни, са съвместно употребени монофлексивно-паратактично без знак за пауза и образуват част от изречението и могат взаимно да се заместват", напр.: Негzliches Gespräch Castro- Tito JW 03.09.1979, Günter Kleiber Ständiger Vertreter der DDR im RGW ND 05.02.1986, Erstmalig Gespräche Großbritannien - ACN ND 05.02.1986, Friedensmeeting Ghana - DDR in Accra ND 05.02 .1986$.

Става ясно, че има явно предпочитание към тези субстантивни словосъчетания, които сочат тенденцията към номинализацията и езикова икономия.

Следните примери, конто вече датират от 1986г. онагледяват ясно, че в немския език се предпочита употребата на би- 
номинални конструкции с апозиционнен характер пред употребата на предложната конструкция:

Sonderkommission zur Untersuchung der Challenger-Katastrophe ND 05.02.1986 се предпочита като синтактична форма, която е максимално съкратена пред възможни други форми като: /примерно/ Sonderkommission zur Untersuchung der Katastrophe von Challenger или пред глаголния вариант от типа на:Sonderkommission untersucht Katastrophe von Challenger, в българската преса съобщението на тази тема носи следното заглавие: "След катастрофата с чальнджър" /и като подзаглавие/ "Поуки от трагедията" Рд б5.б2.1986. В българския език се предпочита предложния вариант на заглавието.

Примери като последният, който посочих от немския печат се срещат във всеки брой на вестниците, особено в съчетание с абревиатурни съкращения /най-често наименования на държави, организации и др. + отглаголно съществително/ срв.: Unterstützung für UdSSR-Vorschlag ND 04.02.1986, UdSSR-Auszeichnung für Ruth Werner und Leon Beurton ND 04.02.1986, Demonstrationen in spanischen städten für NATO-Austritt ND 05.02 . 1986, Puppenbühne Magdeburg mit DDR-Erstaufführung ND 12.02 . 1986, Acht Außenminister für Stop der USA-Hilfe an die Contras ND 12.02 .1986 .

В българската преса заглавия задържащи апозиционни син-

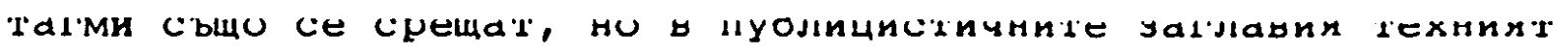
брой не е толково висок, както в немските, в самите статии се наблюдават повече, срв.: Взаимодействието "наука-производстВо" РД 01.01.1984, КонФликтът Иран-Ирак РД 23.01.1986. Ннтересно е, че в немската преса това съобщение е пак с апозиционна синтагма, срв.: Weitere starke Gefechte im Konflikt Irak-Iran ND 12.02 .1986 .

Много по-често в българските публицистични заглавия срещаме биноминални прилагателни изрази, които служат пак за приложение и определение на съществителното, напр.: "научнотехническият прогрес в моя труд" РД 24.02.1986, научно-техническата революция и идеологията" РД 05.02.1986, "Подписани съветско-корейски документи" РД 23.01.1986, изяви на българо- 
съветската дружба Рд 15.01.1986.

Но апозитивни биноминални конструкции от типа на: Колективи-първенци РД 24.02.1986 или Декларация-призив РД 17.03. 1986 не са рядкост като заглавия и подчертават несъмненната тенденция към номинализация.

2. 2. 4. Немски публицистични заглавия, които представляват партиципиални и инфинитивни конструкция

Този вид заглавия в немския език се среща сравнително често /в 108/и от лингвистична гледна точка е извънредно интересен. Партиципиалните и инфинитивните конструкциимоскальская/197.5/ определя като словосъчетания с ранг на изречение. Те изразяват едно пълноценно изказване, защото в тях има имплицирана субектно-предикатна връзка. Те изразяват едно пълноценно изказване и в същото време са по-кратки. Затова те са един от предпочитаните варианти на немските заглавия. Те съдържат само същественото от информацията, напр.:

a/ инфинитивни конструкции:

Rassisten planen Wasserraub ND 28.08.1985, Zu Gesprächen entscheiden ND 24.05.1979, Chemiedozenten diskutieren ND 29. 03.1979, Tagespläne bei Abraum und Kohleförderung überboten ND 29.01.1985, Kulturschaffende aus Finnland besuchen DDR ND 11.04.1979, Eisenacher laden zum Sommergewinn ND 11. 04.1979, FDJ-ler schreiben Chronik ND 29.03.1979.

6/ партиципиални конструкции:

Goldener Degen gestohlen ND 28.08.1985, Goldpreis gestiegen ND 12.12.1979, Kosmos 1147gestartet JW 13.12.1979, Spittelkolonaden eingeweiht ND 17.12.1979, Raumschiff "Sojus T" gestartet ND 17.12.1979, Halbfinale ausgelost ND 29.01.1979, Transportmittel rationell genutzt JW 11.04 .1979 .

При примери с инфинитивни форми като: Ubereinstimmende Positionen sind stärker $z u$ berücksichtigen ND 18./19.02.1984, Beziehungen zu sozialistischen Ländern verbessern ND 18.08.1984, се наблюдава дори една имплицитна закана за по-нататъшни действия от ранга на подбуда. 
Прави впечатление, че в немския език по-често е възможно да се изпусне спомагателния глагол, при което се получава една комуникативно допустима конструкция и която се характеризира от автори като Юнг /1982/ като "typische Schlagzeilen" /типични заглавия на вестници/, това са:

2. 2. 5. Елиптични изречения в немските публицистични заглавия с изпускане на спомагателния глагол

Te cе намират във всеки вестник, напр.: Wirtschaftsgespräche von BRD und UdSSR sehr erfolgreich ND 29.01.1985, Kumpel von Arizona seit sieben Monaten im Streik ND 18./19. 02.1984, Petra Falke dicht am Weltrekord ND 28.06.1985, Balaton fast mückenfrei JW 17.08.1979, Sechs DDR-Ruderboote in den WM-Vorläufen vorn ND 28.08.1985, Botschafter der UdSSR für baldigen SALT II-Abschluß ND 29.03.1979, Archäologen bei Ismaila fündig ND 29.01.1985, S-Bahn - Verkehr verändert ND 03.04.1979, Stationierung von USA-Raketen völkerrechtswidrig ND 29.01 .1985

Когато в словосъчетанието има общи елементи, те се изпускат, зашото това не пречи на комуникацоннния процес, например: Festspiele der Kinder und Jugendlichen in der KVDR eröffnet ND 18./19.02.1984, вместо Festspiele der Kinder und Festspiele der Jugendlichen in der KVDR eröffnet, или Nachwuchs im 200 und in der Natur Bmecto: Nachwuchs im 200 und Nachwuchs in der Natur.

2. 2. 6. Немски публицистични заглавия, които представляват пълни изречения

Тези заглавия заемат една трета от всички немски публицистични заглавия. Такива заглавия дават една пълна и подробна информация, те са обикновено заглавия на по-големи статии, напр.: Künstler aus aller Welt bieten glanzvolle Programme ND 28.08.1985, In Angola bewähren sich 9000 LKW aus Ludwigsfelde ND 18.09.1984, Michael Gorbatschow kondolierte 
zum Tod von Samantha Smith ND 28.08.1985, Die Niederlande feiern den 40. Jahrestag der Befreiung ND 29.01.1985, Das Chile Pinochets ist eine Hölle der Gewalt ND 29.01.1985, Das Beispiel der Kommunisten wirkt in allen Kollektiven ND 29.01. 1985, 2,5 Millionen Spanier haben keinen Arbeitsplatz ND 29. 01.1985, Der "Rumtopf" ist angesetzt ND 29.01.1985, Kubas Frauen sind auch heute die "Seele der Revolution" ND 28.08 . 1985 .

В немските публицистични заглавия най-често синкопираната част на изречението е определителният или неопределителният член, напр.:

a/ изпускане на определителният член: Sowjetunion und Laos vertiefen den Bruderbund ND 28.08.1985, вместо: Die Sowjetunion und Laos vertiefen den Bruderbund, Dienstleistungssektor wächst ND 28.08.1985, вместо: Der Dienstleistungssektor wächst, Lebenslage von Jugendlichen in der BRD hat sich wesentlich verschlechtert ND 29.01.1985, вместо: Die Lebenslage der Jugendlichen in der BRD hat sich wesentlich verschlechtert, Zusammenarbeit mit Polens Gewerkschaft wird vertieft ND 29.01.1985, вместо: Die Zusammenarbeit mit Polens Gewerkschaft wird vertieft.

6/ изпускане на неопределителния член: BRD-Fischkutter verletzte DDR-Territorialgewässer ND 28.06.1985, вместо: Ein BRD-Fischkutter verletzte DDR-Territitorialgewässer, Erdbeben erschütterte Pakistan und Nordindien ND 18./19.02. 1984, вместо: Ein Erdbeben erschütterte Pakistan und Nordindien, Moskau erhält Meeresaquarium ND 29.01.1985, вместо: Moskau erhält ein Meeresaquarium. При всички тези примери ce касае за единичен предмет или явление, което не е пояснено чрез атрибути, тук се употребява неопределителния член.

Но тези изречения със синкопирана членна форма се употребяват в публицистиката равностойно с пълните изречения. Срещаме, макар и по-рядко, в немските публицистични заглавия отделни думи, които изпълняват функцията на заглавие, но не можем да ги причислим към групата на словосъчетанията, пора- 
ди граматичната дефиниция на словосъчетанието, но те изпълняват комуникативната Функция равностойно като тях, срв.: Freizeitmagazin JW 17.08.1979, Filmwiedersehen JW 17.08.1979, Geschwindigkeitsrekord ND 11.04.1979.

Бихме могли да квалифицираме тези заглавия като найконцентрираната форма на номинализацията в немските публицистични заглавия. Дори прилагателни се срещат в тази група, срв.: Unwahrscheinlich JW 03.09.1979.

С тези примери приключваме наблюденията върху граматико-синтактичните особености на немските публицистични заглавия и тяхната функция като сигнал и конспект на информацията за читателя.

Следната таблица ще онагледява тези наблідения:

Вид на граматичната структура

1

Отделни думи

Партиципиални и инфинитивни конструкции

Безпредложно-именни словосъчетания

Прономинални словосъчетания

Предложно-именни словосъчетания

Елиптични н едносъставни изречения

Пълни изречения

ВСичко
В немските публицистични

$$
\text { заглавия, в } 8
$$

4,2

11,3

16,6

1,2

3,3

30,0

100,0 
2. 3. изводи

В заключение можем да кажем следното за наблюденията върху немските публицистични заглавия:

Заглавията на публицистичните материали отразяват нагледно съвременното състояние на немския книжовен език и сочат тенденцияте в неговото развитие.

1. Наблюденията установиха, че преобладават субстантивните словосъчетания и то многосъстаните субстантивни словосъчетания.

2. Прочесьт на отпадане на определителния член е ясно изразен в немските заглавия, той отпада в публицистичните заглавия дори там, където неговата употреба в говоримата реч е задължителна.

3. Като определителни елементи в субстантивните словосъчетания най-много се наблюдават прилагателните имена, други съществителни или предложни групи.

4. Често срещаните групи от словосъчетания, едносъставните изречения и елиптичните изречения, в конто липсва сказуемото изразяват все пак в комуникативен план едно пълно, но кратко и стегнато съобщение.

5. Партиципиалните и инфинитивните конструкции с ранг на изречение се употребяват като пълноценно изказване с имплицирана субектно-предикатна връзка.

6. Установихме, че в немския език е възможно да се изпусне спомагателния глагол, при което пак се получава комуникативно допустима конструкция.

7. В синтактично отнашение в немския език преобладава съгласуването и рекцията, което подчертава синтетичния характер на немския език.

Резюмираио можем да кажем, че в немските публицистични заглавия има явно предпочитане към субстантивните словосъчетания /в 508 от материалите/, а от друга страна срещаме и много разнообразни партиципиални, инфинитивни и други вербални конструкцин. Така, че въпрекн явната тенденция към номинализация н езикова икономия в немската публицистика/коя- 
то се критикува от немските езиковеди/ наблюдаваме и много разнообразии глаголни конструкции в немските публицистични заглавия . 


\section{0. СРАВНИТЕЛЕН АНАЛИЗ НА БЪЛГАРСКИТЕ И НЕМСКИТЕ ПУБЛИЦИСТИЧНИ ЗАГЛАВИЯ}

В първата и втората глава на тази работа вече са анализирани подробно особеностите на българските и немските заглавия, а сега ще се опитаме във вид на резюме да изтъкна разликите и сходствата в заглавията на двата езика. Най-точните резултати ще ни даде статистическия анализ, но ние няма да се ориентираме само по цифрите. Винаги трябва да се има предвид, че се разглеждат тук два езика с различен характер, аналитичен и синтетичен, които имат съответно различни възможности на изразните средства и че "не трябва да се търси винаги граматично и семантично единство и тъждество между синтетични и аналитични Форми, между граматичните средства на аналитични и синтетични езици." /Попов 1973, стр. 114/

Направените наблюдения трябва да се обощават и да се представят изводи и тенденции за развитието на двата езика.

Както вече посочих, корпусът, т. е. материалите за тези изследвания представляват общо 8000 публицистични заглавия, от които 4000 заглавия са от българските вестници "Работническо дело" и "народна младеж" /от всеки вестник по 2000 заглавия/ и паралелно към тях 4000 заглавия от вестниците на ГдР "нойес Дойчланд" и "юге Велт" - сыо по 2000 заглавия от всеки вестник. Четирите вестника са ежедневници и едновременно най-големите и най-важните вестници на нашите държави. Периодът на събирането на тези материали е от 1979г. до 1985г. за това по-обтирно изследване, но аз продължавам да събирам тези материали с голед на някои други съпоставителни изследвания.

С помощта на тази таблица искам да онагледя количественото съотнотение на отделните синтактични структури на българските и немските публицистични заглавия в съпоставителен план. Тъй като при разглеждането на българските публицистични заглавия в първата и втората глава на работата са посочени вече главните резултати и изводи искам да ги представя тук в по-стегнат вид, в съпоставителен план. 
Целта е да се подчертават разликите и сходствата в двата езика, върху които ще се спря по-аодробно в четвъртата глава, която е посветена на превода на българските публицистични заглавия на немски.

3. 1. СЪПОСТАВИТЕЛНА ТАБЛИЦА НА ГЛАВНИТЕ ГРУПИ НА БЬЛГАРСКИТЕ И НЕМСКИТЕ ПУБЛИЦИСТИЧНИ ЗАГЛАВИЯ

В $И$ Д

1

Безпредложно-именни словосъчетания

1890

$$
47,28
$$

1336

33,40 заглавия брой के

45

66416,60

$$
0,90
$$

45

Партиципиални и инфинитивни конструкции

Прономинални словосъyetarns 42 1,05 48 1,20

Да- конструкции

96

$$
2,44
$$

Елиптични и едносъставни конструкция

$$
2,31
$$

132

3,30

Из речения

744

$$
18,61
$$

1200 30,00

Отделни думи

0бщо
208

$$
5,18
$$

168

4,20

4000 
3. 2. изводи

1. Преобладаващият вид на публицистичните заглавия, както в българския, така и в немския език са субстантивните слово. съчетания. Наблюдаваме голямо сходство при простите и съставните субстантивни словосъчетания в двата езика. В немския език, за разлика от българския, преобладават многосъставните словосъчетания .

2. В немските субстантивни словосъчетания в множеството липсва определителния или неопределителния член пред субстантивът, дори там, където присъствува в говоримата реч. /Грим, 1981/ Тъй като членът в българския език е "формообразуваща морфема" /ГСБКЕ, том 2 , стр. $118 /$, а не отделна дума като в немския език, този процес на отпадането на определителния член в българските заглавия не е така ясно изразен както в немските /срв. глава 2/. Върху този въпрос обръщам в четвъртата глава при превода на членувани и нечленувани имена от български на немски специално внимание.

3. Определеителните елементи в субстантивните словосъчетания и в немския и в българския език са най-често прилагателните имена или други съществителни или пак предложни групи. Но срещаме и приложения като пояснителен елемент в публицистичните заглавия, които представляват субстантивни словосъчетания /срв. глава 2, Хакел 1972.стр. $341 /$. ази тенденция не е нова, но се наблюдава все по-често, особено в немския език.

4. Тенденцията към максималното съкращение на фразата се откроява много ярко в немския език. Това сигнализира високата фреквентност на употребата на сложните думи и съкращения.

5. В българските и в немските заглавия има много групи от словосъчетания или едносъставни изречения, в които липсва сказуемото. Сказуемото се подразбира от контекста и по този начин този тип заглавие е равно на едно пълно съобщение.

6. Партиципиалните и инфинитивните конструкции, които 
в немския език пак се определятс ранг на съобщение /Москальская, $1975 /$ се употребяват често в немската публицистика, в българските заглавия ги срещаме по-рядко, там причастните форми повече иэпълняват ролята на съгласувани определения. това означава, че те остават в рамките на субстантивните словосъчетания .

7.В немските заглавия установяваме, че много често е възможно да се изпусне спомагателния глагол и пак се получава една "комуникативно допустима конструкция" и вероятно С това се обяснява честата употреба на партиципиални конструкция в немските заглавия.

8. Различията в тези два езика в областта на вербалните заглавия са несъмнено свързани с отсъствието на инфинитива в българския език. Наблюдаваме, че инфинитивът се изразява чрез да-конструкция /срв. глава 4, където този въпрос е разгледан подробно във връзка с превода на да-конструкциите на немски/.

9. Относно синтактичните връзки в немския език преобладават съгласуването и рекиията, които отразяват синтетичния характер на този език. А в българския език наблюдаваме съгласуването чрез предлози, които ясно изразяват неговия аналитичен характер.

10. Заключително се установява, че в немския език

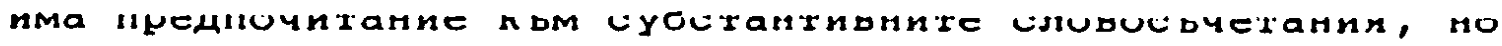
за разлика от българските заглавия - откриват се много почесто вербални словосъчетания, партиципиални и инфинитивни конструкция. Въпреки тенденцията към номинализация и езикова икономия в немския език/която се критикува от езиковедите/ в публицистичните заглавия се намират по-разнообразни форми, отколкото в българската публицистика. При българските заглавия се наблюдава максимално изпускане на глаголните форми. Но моите наблюдения от 1979Г. насам в тази насока твърдят, че има една положителна тендениия при оформлението на българските публицистични заглавия, те да станат по-динамични и по-разнообразни и по този начин да бъдат поувлекателни за читателя. 
4. 0. НЯКОЛКО ИЗСЛЕДВАНИЯ ОТНОСНО ПРЕВОДА НА БЪЛГАРСКИТЕ ПУБЛИЦИСТИЧНИ ЗАГЛАВИЯ В НЕМСКИЯ ЕЗИК

4. 1. ТЕОРЕТИЧНИ ПРЕДПОСТАВКИ

Най-напред ще се опитам да изясня какво съдържание се включва в понятието "превод", ще представя една обща постановка на това понятие и ще посоча неговите граници. Думата "превод" има в българския език доста широка тематична гама, от която тук ще изследвам само:

а/ превода като процес /т.е. самото превеждане/

б/ превода като резултат от процеса /T.е. предадени на друг език думи, текст и др./.

Един еднозначен отговор на въпроса "Какво е превод?" няма, защото самата човешка дейност, която се извършва в процеса на превода е сложна и многостранна.

Преди всичко трябва да се акцентува върху неговата социална същност и природа и върху социалните Функции на превода. Научната теория за превода няма да се разбере, ако не се възприеме становището, че преводът е обществено явление и може да възникне само в обществото. Следователно, като обществен продукт той е резултат на едно историческо развитие, защото преводът се явява на определен етап от общественото развитие, което се нуждае вече от превода и необходимите условия за превода са вече създадени. Така преводът е претърпял едно дълго, историческо развитие, а в наше време той е вече едно основно средство за осъществяване на общуването, сътрудничеството и взаймодействие между държавите и народите в нашата епоха. Може да се каже, че XX-ти век е век на инФормационни лавини, на научно-техническата революция и на "тоталния превод" като се има предвид какво огромно количество книги, списания и др. се превеждат и каква важна роля играе устният превод днес. Преводът е един Фактор на нацоиналната и световна култура. Преводът е едно ценно културно явление.

Но тъй като преди всичко преводът е езикова дейност, 
ще разгледаме неговите лингвистични основи. Винаги трябва да се помни, че преводът не е изолиран от действието на лингвистичните закони, неговата основа е езикът. Той предава определена информация или една определена система от художествени образи от един език на друг.

Преводът е:

1. Социално явление

2. Отражение на реалната действителност, която е намерила отражение в оригинала.

3. Адекватно отражение на оригинала, който се превежда

4. Творческо пресъздаване на оригинала

5. Декодиране, ново кодиране и предаване на познание и ннформация .

Съществуват многобройни дефиниции и определения на превода като процес и резултат от видни учени в областта на превода като: А.В. Феодоров, Ю. Д. Левин, В. Кодлер, Б. Здун, О. Каде, Г. Яегер, И. Левий, Н.П. Вине и М. Дарбелне и др. невъзможно е да се изброят тук всички имена на тези, които допринасяли за пълното и по-точното определение на превода. ние ще приемем една дефиниция, която ще послужи едновременно и като основа за разработката на превода като процес и като резултат и която е разпространена и в българската литература в тази област /виж изследванията на Л. ризор, Ал. Люцканов, и И. Васева и А. Лилова по тази тема/.

О. Каде /1968, стр. 35/ дефинира писмения превод така: "Wir verstehen unter Ubersetzen die Translation (lat. translatio - предаване) eines fixierten und demzufolge permanent dargebotenen bzw. beliebig oft wiederholbaren Textes der Quellensprache in einen jederzeit kontrollierbaren und wiederholt korrigierbaren Text der Zielsprache".

А устният превод е:

"Unter Dolmetschen verstehen wir die Translation eines einmalig dargebotenen Textes (in der Regel mündich) der Quellensprache in einen nur bedingt kontrollierbaren und infolge Zeitmangels kaum korrigierbaren Text der Zielsprache." 
Следната схема ще онагледява разликите между устния и писмения превод, които се съединяват под събирателното название - транслация:

Unterschiede zwischen Ubersetzen und Dolmetschen als Teilklassen der Translation

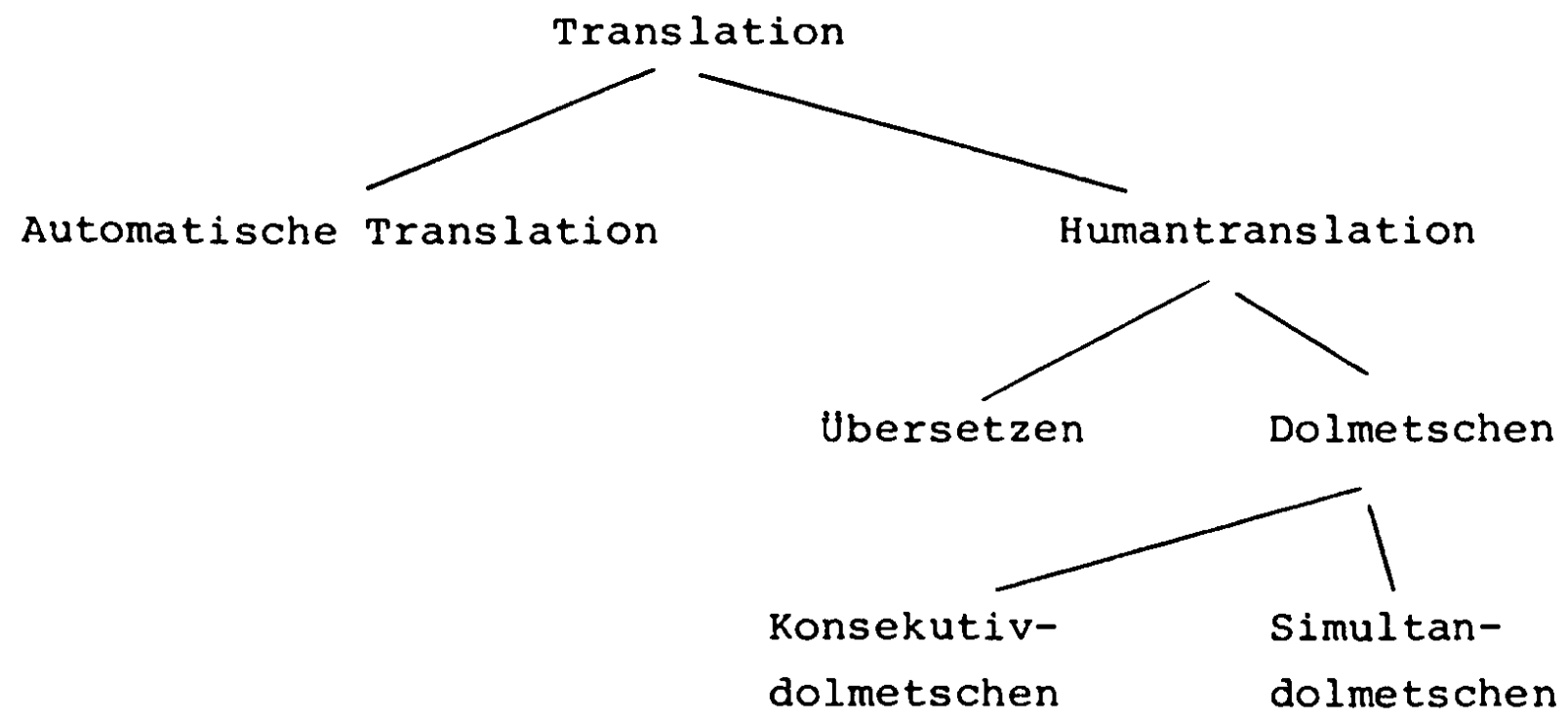

Ние изхождаме от становището, че преводът е устна или писмена дейност за пресъздаване на съществуващия в един език устен или писмен текст на друг език като при пресъздаването се запази инвариантността на съдържанието и качествата на оригинала и на авторската автентичност.

Като се разглежда историята на преводознанието, която изследва общите закономерности, присъщи на превода /т.е. проучаване и систематизиране на неговата природа, приниипите, които трябва да се спазват и др./, често пъти срещаме противоположни мнения, които допринасят за развитието на преводознанието. Така например А. А. Реформаторски и В. Блаже и др. са твърдели, че "преводът не може да има своя наука". След тях дълго време е съществувал спор между тези преводоизследователи, които са били привърженици на "духа" и онези, които твърдят, че "буквата" е центъра на превеждането. Но в 
последните години има комплексен подход към проучването на превода, който дава най-добри резултати. Стана ясно, че сътрудничеството с другите науки е абсолютно необходимо, както твърди и М.Пернис /1973/, К. Райс /1979/ пише: "Преводачният процес не е чисто лингвистична операция. Езикознанието, литературознанието, теорията на информацията, психологията, социологията, етнологията са само част от научните дисциплини, които трябва да дадат своя принос за изясняването на взаимностите, условията и границите на превода.

Следователно взаимодействието между теорията на превода и другите науки не е еднопосочно, а двупосочно, и то ще се задълбочава и развива заедно с развитието на теорията на превода. Общоизвестно $е$, че лингвистиката и литературознанието чрез преводознанието могат и да решават и редица свои собствени проблеми и въпроси. Преводознанието получава От литературознанието ценни ФилосоФски и исторически аспекти, а лингвистиката с нейните нови методи за изследване допринася за нови теоретични постановки, например на художествения превод. И. Васева /1985/ чрез анализи на материали от художествената литература е създал една "реалистическа теория на превода", която се изгражда върху литературоведска основа и дава много ценни резултати за преводознанието.

Тъй като преводът е предназначен за обществото или за отделни индивидии от него, преводознанието има връзка и със социологията, която изучава обществото и неговите закони. Връзката с тази наука ще се покаже много ясно при превода на заглавията на вестници, тъй като заглавието се разглежда и от аспекта на потребностите на обществото.

Преводознанието е неделимо Свързано с философията. Тя дава ключ за разкриване на специфичния творчески характер на превода /при това не само на художествения/, така и за разработване на методологията на неговото изследване а именно зависимостта на превода от историческите условия, класовата обусловеност на мирогледа на преводача, върху този въпрос ше се спрем подробно по-нататък, въздействието на измененията в обществения живот върху различни направления в 
преводознанието. Естествено и другите обществени науки като историята и психологията са близки до преводознанието. През последните две десетилетия точните науки /математиката, кибернетиката, теория на информацията, теория на сложните системи и т. н./ са дали голям принос за развитието на превода и на преводознанието и несъмненно този процес има големи перспฺективи за всички области на превода. Изработват се модели на някои преводачески операции или някои стъпки на превода, които могат да бъдат от полза и за машинния преводач. След като са разгледани многобройните дисциплини, конто стоят в непосредствен контакт с преводознанието и с превода като явление, процес и резултат, ще се опитаме да изброим неговите аспекти, които са необходими, когато се започне неговото разглеждане и изследване.

1. Първият и най-важен аспект е неговата социална природа, тъй като той е пряко свързан с обществото и неговата комуникация .

2.Преводът е едно културно явление. Ние трябва да го разберем като част и средство за развитие на националната култура, като пласт и фактор на културните процеси.

3.Както вече е казано, основен въпрос за понятието "превод" е неговият лингвистичен аспект, езикът е фундаментът и основното средство на превода.

4.Преводът има обща качествена определеност, характерна и валидна за всички негови форми и видове. По-специално за "художествения" превод" трябва да бъде разгледан неговия художествено-естетически аспект, естетическата същност и образната му природа.

5. Отражението и творчеството са основни аспекти на понятието "превод" у диалектиката на отражението и творчеството са базисен момент в неговата природа.

6. Един основен аспект - творческата природа е един сложно съставен и сложно функциониращ процес, в резултат на който се създава преводната творба.

7. И не накрая, преводът е едно историческо явление и трябва да се разглежда като исторически процес. 
и така, след като се опитахме да изложим един отговор на въпроса "що е превод?", след като го разгледахме и характеризирахме като историко-култүрно явление и като творчески процес стигаме до извода, че преводната творба като резултат е сложен, разностраннен, многосъставен и полифункционален феномен.

И при всеки опит да бъде пренебрегната една от посочените точки или едната или другата му Функция води непременно до деформацията в научно-теоретичното му познание. Ние трябва да направим едно всестранно материалистическо изследване, което ще ни води до истината на превода.

Тук трябва и да обърнем внимание върху проблема на диалектиката на съдържанието и формата в процеса на превода и при резултата, т. е. при самия превод. Ние изхождаме от тази гледна точка, че взаимоотношението между съдържанието и формата на оригинала в процеса на превода и в резултат от този процес трябва да бъдат предавани адекватно. Това е най-сложната задача в прочеса на превода и онагледяване трудната и отговорната работа на преводача.

ние бихме могли да си представим, че преводът е едно пресъздаване на съдържанието н Формата на оригинала с езиковите средства на друг език. И винаги преводачът трябва да се стреми да запазва и да изразява това единство на съдържанието и формата на оригинала.

Тази задача съвсем не е лесна, когато се касае за превода на публицистични заглавия от български на немски. Както ще докажат примерите после, преди всичко темата и идеята на заглавието и на статията, т. е. идеологически и политически интерпретираната тема трябва дабъдат водещите елементи при такъв превод, което означава, че водещата роля има съдържанието. Това се обуславя от самите компоненти, конто образуват същността на заглавието. Така например призивния характер, който е свързан с идеята на заглавието, трябва а бъде пресъздаден чрез субективното виждане на автора на превода /преводача/.

Автонимността на Формата не може да се абсолютизира, не може да се разглежда откъснато от самото съдържание, от 
обществените ситуации, от политическите обстоятелства, от традиционно- литературни въпроси и др. Ако се анализират и превеждат само елементи на формата, откъснати от цялото и от смисъла, няма да се получи превод с въздействието на оригиналното заглавие, защото всеки елемент е съдържателен и съществува като елемент на формата само към определено съдържание, което изразява.

Като си представим сега конкретно действието на превеждането на заглавия, следва да разгледаме следните постъпки: Първо, още преди да започне превеждането на оригинала, преводачът се запознава съсзаглавието и със статията като читател. Значи, той възприема съдържанието и формата не като абстрахирани елементи, а в тяхното единство. За разлика от един научен анализ преводачът не разкъсва това единство. Той трябва да възприеме и да разбере съдържанието и формата в тяхната хармонична неделимост и след това да възпроизведе това съдържание във Функиионално-аналогична на оригинала форма. като извод можем да потвърдим:

Преводачът трябва да търси в съдържанието и идеята, също така и в темата и извадения от нея сюжет и в изразните средства. Ограничаването само в езика/който е един от елементите на формата/ и пренебрегването на идейно-тематичното начало /което принадлежи към съдържанието/ може да доведе до разкъсване на единството на съдържание и Форма, до невярна и неправилна интерпретация на съдържанието, даже до абсолютни безсмислици в превода.

Диалектическата природа на превода откриваме и във взаимоотнотението между националното и интернационалното в оригинала и в преводната творба.

Това е един въпрос, който в миналото и в днешни буржоазни теории за превода е оспорван и буди интерес не само от страна на лингвистите, но и от литературоведи, историци и писатели. В редица западноевропейски държави можем да открием трудове, които твърдят, че възможността да се осъиестви пълноценнен превод не съществува, запото "езикът е пряко и рационално отражение на народния дух, на който не могат да 
бъдат намерени съответсвия на другия език" /Феодоров 1968 , стр. 44/. Тези идеи водят началото си още от миналия век, намираме ги в трудовете на В. Фон Хумболдт, след това при Е. Сепир и и Лео Вайсбергер, които ги поддържат до днес, те намират отражение в трудовете на на авторите от ФРГ като Клопфер и Здун. Основния недостатък на тези теории и разработки е, че те изхождат от погрешни методологически позиция. Те разглеждат превода откъснато от обществото, ограничава се социалното изследване на превода, социологическия анализ е съвсем пренебрегнат. Такъв подход несъмненноводи до грешни резултати.

ние трябва оне веднъж да подчертаем, че преводът е част от общите социални процеси. Ние се присъединяваме към съвременните позиция на материалистичното преводознание, както Ги изразява Феодоров /1973/ и Каде /1964/: Едно от наиважните постижения на съветската теория на превода е разграничаване на категориите от формите на езиковото и литературното явление от една страна, а и на неговата смислова и художествена функция, от друга страна. Ако за формите средствата на един език, на една литература липсват, тогава преводът ще бъде само лъжлив. Пълноценният превод съществува, т. е. по пътя на избора на други съчетания, на други формални средства на този език, на който се пресъздава оригинала. На това всъиност базира принципа на преводимостта.

$$
\text { Прододит иа рагладиव и птатии пт рогтииiи о но гамп }
$$

важна, но и отговорна задача. Важна e, защото по този начин читателите в другите държави получават ценна информация за външно- и вътрешнополитическите събития в страната, а ролята на преводача е много отговорна в това отношение, защото, както вече изтъкнахме при въпроса за диалектическото единство между съдържание и форма, изключително важно е да се направи един точен превод, който предава не само самото съдържание, но и призивния характер на заглавието. Ние ще видим по-нататък, че тази задача изисква една солидна подготовка на преводача, който трябва да бъде информиран винаги за актуалните събития, който трябва да владее отлично немския и българския език и който трябва да има съответно зна- 
ния в областта на странознанието на двете страни.

Сега ще направим един конкретен анализ на превода на българските заглавия на немски език и ще разгледаме възможностите на тяхното предаване като обръщаме внимание на съдържанието, формата и призивния им характер и преводът ще бъде такъв, че да отговаря на немско заглавие на вестник.

В първата глава се разглеждаше подробно структурата на българските публицистични заглавия и там има и схеми, които онагледяват най-големите групи на българските заглавия според тяхната граматична и синтактична структура. Ceга ще се опитаме да дадем възможности за превода на петте големи групи. Става дума за: 1. Безпредложни-именни словосъчетания, 2. Предложно-именни словосъчетания, 3. изречения, 4. Да-консрукция, 5. Незавършени и непълни синтактични конструкция и техните подгрупи.

При първата група на българските публицистични заглавия, това са:

Безпредложно-именни словосъчетания

Преводът на немски не крие неочаквани трудности на синтактичро или семантично равнище, конто биха затруднили намирането на еквивалент в немския език.

Отделните подгрупи на безпредложните именни словосъчетания са:

1. Заглавия от типа: прилагателно име + съществително име

2. Заглавия от типа: числително име + съществително име

3. Заглавия от типа: лично местоимение + съществително име

Както става ясно от примерите, тези словосъчетания имат преки еквиваленти на немски, където този вид заглавия също е разпространен във висша степен /около $408 /$.

4. 2. ПРЕВОД НА ПУБЛИЦИСТИЧНИ ЗАГЛАВИЯ, КОИТО СА ПО ФОРМА БЕЗПРЕДЛОЖНИ ИМЕННИ СЛОВОСЬЧЕТАНИЯ ОТ БЬЛГАРСКИ НА НЕМСКИ 
4. 2. 1. При безпредложно-именни словосъчетания най-голямата фреквентност имат словосъчетанията от типа на A + S/прилагателно + съществително, прилагателното $\mathrm{e}$ подчинено/, което наблюдаваме като във функция на заглавия във всеки от представените ежедневници. Те служат за:

a/ квалификация на лице:

"Скромният шампион" РД 09.01.1984

"Безупречният контрольор"

Рд 13.01 .1984

6/ квалификация на предмет:

"Висококачествен цимент"

РД 06.11 .1984

"Целебна вода" РД 12.01.1984

"Дълбоки корени" РД 15.01.1984

"Майсторски творби" РД 01.01.1984

"Работнически Фамилии"

Рд 04.01 .1984

"Нови платове" РД 07.01.1984

"Богат асортимент" РД 09.01.1984

"Нови жилища" РД 03.01.1984

"Търпеливи ръце" Рд 21.02.1985

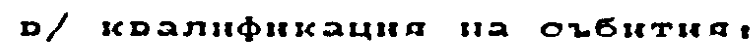

"Творческа среща" РД 16.02.1984

"Съвместно заседание"

Рд 17.01 .1984

"Приятелско посещение"

РД 17.01 .1984

Г/ квалификация на абстракта:

"Внсока боеготовност"

РД 13.02 .1984

"Активен реализъм" РД 15.02.1984

"Драматичен финал" Рд 16.02.1984

"Братско единство" РД 03.05.1984
Der bescheidene sieger

Der tadellose Kontrolleur

Hochwertiger Zement

Heilquellenwasser

Tiefe Nurzeln

Meisterwerke

Arbeiterfamilien

Neue Stoffe

Reichhaltiges Angebot

Neue Wohnungen

Geduldige Hänđe

Schöpferisches Treffen Gemeinsame Sitzung

Freundschaftsbasuch

Hohe Kampfbereitschaft

Aktiver Realismus

Brüderliche Einheit 
"доброто настроение"

Рд 16.01 .1984

"Дълбоки различия" РД 16.02 .1984

"ядрена безотговорност"

Рд 24.01 .1984

"Братско сътрудничество"

Рд 18.01 .1984

"Искрена благодарност" Рд 10.01.1984 Aufrichtige Dankbarkeit

"Политическа провокация"

РД 10.01 .1984

д/ Заглавия, при които две прилагателни имена характеризират едно съществително име /реални и абстрактни понятия/

"нова поликлинична база"

РД 20.01 .1984

"Нов почивен комплекс"

РД 10.01 .1984

"нови социални придобивки"

Рд 10.01 .1984

"Богата концертна програма"

РД 14.01.1984

"Съвместни научни разработки"

РД 09.01 .1984

"широко практическо приложение"

РД 24.01.1984

"Богата социална програма"

РД 20.01 .1984
Die gute Stimmung

Große Differenzen

Atomare unverantwortlichkeit

Brüderliche Zusammenarbeit
Politische Provokation

4. 2. 2. Числително име + прилагателно + съществително име: Тези форми, независимо дали съдържат бройни или числителни по-рядко се срещат, преводът им се осъществява по следниния начин:

"10-хилядната машина"

Die 10 000. Maschine

Рд 20.01 .1984

"Първото поръчение"

Die erste Empfehlung

Рд 11.01 .1984 


\begin{abstract}
"Седемте сестри" РД 17.01.1984
Die sieben Schwestern

"Два големи таланта" РД 08.01.1984

Zwei große Talente

"Пет български пиеси"

Fünf bulgarische stücke

Рд 08.01 .1984
\end{abstract}

4. 2. 3. Лично местиомение + съиествително име:

Преводът на този вид заглавия от български на немски не

крие неочаквани трудности, както се вижда от примерите:

/членувани/

"Нашият насрещен план"

Unser Gegenplan

HM 07.12 .1979

"Вашите въпроси - нашите отго-

Ihre Fragen - unsere Antвори" НМ 07.12.1979 worten

"нашата демокрация"

Unsere Demokratie

Рд 24.02 .1986

"нашата отговорност"

Unsere Verantwortung

РД 24.02 .1986

В заключение за превода на тази първа група заглавия можем да кажем: Тези словосъчетания се употребяват в немските и в българските ежедневници често, те се превеждат обикновено дословно, изключения правят случаите, когато вместо българското словосъчетание "прилагателно + съществително" се употребява един немски композитум /напр. "Работнически фамилия"

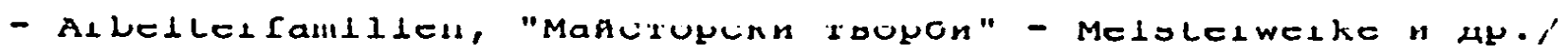
на няколко особености в употребата на членуването е обърнато внимание при самите примери от тази група.

4. 2. 4. Превод на публицистични заглавия, конто са по форма предложно-именни словосъчетания от български на немски

В българските публицистични заглавия, конто са по форма предложно-именни словосъчетания, предлозите играят изключително важна роля /виж глава първа/.

Функцията на всички предлози да изразяват отношения в 
реалния свят е еднаква в българския и в немския език. Но сравнително високата степен на десемантизацията на българските предлози изисква от преводача и познания по историческото развитие на българските предлози да не се пренебрегне едно от значенията на всеки отделен предлог. Освен това в българските предложно-именни словосъчетания няма такива каузални отнотения, както в немския език, въпреки това, че в новите граматики /Юнг, 1982, Хайдолф, Флемиг, Моч 1981/ на немски език се твърди, че предлогът обозначава едно отнотение попряко и по-еднозначно отколкото чистата падежна форма. Затова формите с предлози се употребяват с предпочитание. Следователно преводачът трябва да бъде запознат с употрбата на предлозите в немския език. /T. е. да знае кога се предпочита каузална и кога се употребява предложна форма и съответно да се употребява правилния падеж, който изисква немския предлог/.

Както е известно в съвременния немски език съществува един casus rectus /Nominativ/, Genitiv, Dativ, Akkusativ, които ca casus obliqui. Рекцията на тези падежи зависи от глаголи, прилагателни, съществителни или предлози /предложни падежи/. В съвременния немски език предложните падежи за сметка на casus obliqui ce употребяват повече /юнг 1982, Флемиг $1981 /$.

Преди да разгледаме превода на самите примери на българските предложно-именни словосъчетания, които се наблидават в публицистични заглавия, искам да обърна внимание на някоя принципни въпроси, които се отнасят към немските предлози.

Предлозите, както в българската, така и в немската граматика са служебни думи. Те представляват синтактичната база на предложната група, обозначават синтактичното свързване с другите синтактични единици. В немския език, както в всички синтетични езици, всеки предлог има една определена рекция /управление на падежа на имената, които стоят след тях/. То- 
ва явление е известно и от старобългарския език, където предлогът според значението си в даден случай се употребява с определен падеж. Така например в старобългарския език вєзх, Ао, отъ, изъ, рали и др. се употребяват само в родителен падеж, кz-само в дателен падеж, междоу - само в творителен падеж, прн - само с местен падеж. Други предлози като ма, по, - ce употребяват с винителен или местен падеж, а предлозите на, надz, подz, прьа С винителен или творителен падеж, за да изразят движение или покой .

С три падежа се употребяват предлозите въ/родителен, винителен, местен/, за/родителен, винителен, творителен/, по /дателен, винителен, местен/. Следи от рекцията на предлозите в новобългарския език се наблюдават при свързването им с местоимения, в системата на които има остатъци от синтетизъм /падежни форми, например след предлога се появява пълната родително-винителна форма на личните местоимения / с мене, от вас, за тях, при него и т.н. - ГСБКЕ, том II, стр. $412 /$.

В публицистичните заглавия откриваме сравнително рядко такива форми, те принадлежат по-скоро на разговорната реч. В съвременния български език предлозите се употребяват за изразяване на всички видове отношения, които се отнасят към конкретни или абстрактни неща или ситуации, без да притежават една определена рекция. А от гледна точка на тяхното зна-

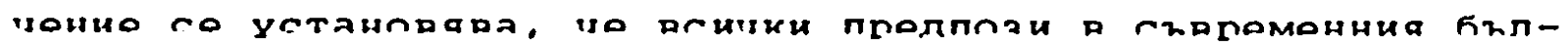
гарски език се характеризират с една сравнително висока десемантизация .

В Съвременния немски език предлозите от семантична гледна точка са натоварени със същите функции, както българските/да изразяват отношения между конкретни и абстрактни неща или ситуации/, а с помощтана предлозите тези отношения се описват много по-специфични и по-точни отколкото чрез чистите падежни форми /Хайдолф 1981, стр. 695/.

Както в българския, така и в немския език предлозите сигнализират следните отношения и обстоятелства:
a/ локални
б/ темпорални 
в / каузални

г/ концесивни

д/ кондиционални

е/ Финални

ж/ обстоятелства за начин и други специфични отнотения.

За произхода на немските предлози се установява същото положение, както при българските предлози, първоначалното им значение е било пространствено, след това влезли в употреба за темпорални и накрая за абстрактни отнотения.

Рекцията на немските предлози е строго определена. Според рекцията можем да разпределим предлозите в следните Групн:

a/ предлози с рекция на GENITIV: abseits, abzüglich, anfangs, angesichts, an Hand, anläßlich, anstatt, anstelle, aufgrund, ausschließlich, außerhalb, behufs, beiderseits, betreffs, bezüglich, diesseits, exklusive, halber, hinsichtlich, infolge, inklusive, inmitten, innerhalb u.a.

6/ предлози с рекция на Dativ:

ab aus außer, bei, binnen, entgegen, fern, gegenüber, mit, nach, nächst, nebst, ab, samt, seit, von, zu, zuliebe, zunächst, zuwider.

в/ предлози с рекция на AKKUSATIV:

bis, durch, entlang, für, gegen, ohne, per, pro, sonder, um, wider.

Г/ предлози с рекция на DATIV и AKKUSATIV:

Тук наблюдаваме едно положение, което прилича на старобългарската рекция. Когато чрез предлозите an, auf, hinter, in, neben ce изразява една целенасочена дейност или едно движение, се употребява Akkusativ, a когато се изразява покой, се употребява Dativ. Тази ситуация познаваме от старобългарските предлози на, наАz, ПоАz, прьА.

Разбира се, съпествуват в немския език случан, когато би могло да се употребява както Akkusativ, така и Dativ. B такнва случан трябва да се обърне вниманне върху рекцията на Глагола, която в значителна степен оказва влияние върху 
рекцията на предлога и на съществителното /Dнг, 1982, стр. $352 /$.

При превода на всяка отделна група на българските публицистични заглавия, които представляват предложно-именни словосъчетания можем да открием тези правила на рекцията на немските предлози.

4. 2. 4. 1. Превод на предложно-именните словосъчетания с предлога без от български на немски:

"Еез" /ohne/ изисква в немския език Akkusativ, на семантично равнище двата предлога изразяват на български и немски същото отношение.

"Без бащин дом"

Ohne Vaterhaus (Akkusativ)

РД 22.01 .1984

"Земеделие без почва"

Рд 11.01 .1984

"Без конкретни резултати"

РД 10.02 .1984

"Без носителя"

нМ 06.12 .1979

"Изкуство без помощ и грижи"

Рд 16.12 .1984

"На старини без бели коси" юд U3.01.1984

"Почти без съпротива"

РД 06.02 .1984
Landwirtschaft ohne Boden (Akkusativ)

Ohne konkrete Resultate (Akkusativ)

Ohne den Titelträger

(Akkusativ)

Kunst ohne Fürsorge und Unterstützung (Akkusativ)

Im Alter ohne graues Haar (Akkusativ)

Fast ohne widerstand

(Akkusativ)

4.2.4.2. Превод на предложно-именни словосъчетания с предлог 8

Както в българския, така и в немския език предлогът "в" е основен предлог с пространствено и абстрактно значение.

След предлога "in" в немския език се употребява Akkusativ, когато едно движение или една дейност се извършва целенасочено /Юнг 1982, стр. $885 /$, в други случаи /при въпроса "Wo?"/ ce употребява Dativ.

например: "Когато самочувствието прераства в безраз- 
съдство" РД 13.01.1984 - Wenn das Selbstbewußtsein in Unüberlegtheit ausartet, или "Висшият форум на западногерманските комунисти се превърна в мощна трнбуна срещу ракетните планове на САщ" РД 07.01.1984 - Das Oberste Gremium der westdeutschen Kommunisten wurde $z u$ einer mächtigen Tribüne gegen die Raketenpläne der USA, в тези случаи се употребява Akkusativ, a в примери като "интензификацията в центъра на вниманието" РД 15.01.1984 - Die Intensivierung im Zentrum der Aufmerksamkeit ce употребява Dativ, примерите ще илюстрират тези правила.

a/пространствени значения:

"напрежение в окупираните територия" РД 30.03 .1984

"Тролейбуси в работническия център" РД 30.03 .1984

"нов паметник в звездното градче" РД 12.01 .1984

"В старата Априловска гимназия" РД 15.01 .1984

"В Пирин - нов курортен комплекс" Рд 30.03 .1984
Angespannte Lage in den okkupierten Territorien

O-Busse im Arbeiterzentrum

Ein neues Denkmal im Sternenstädtchen Im alten Aprilov-Gymnasium

Ein neues Erholungszentrum im Pirin

б/ конкретна номинализация на град или държава:

"Cреща в Казабланка"

РД 17.01 .1984

"Заседание във Варшава"

РД 20.01 .1984

"Обстановка в Чад"

РД 30.01 .1984

"Съвещание в Кабул"

РД 09.01 .1984

"Обиата стачка в Уругвай"

Рд 20.01 .1984
Treffen in Casablanca

Sitzung in Warschau

Die Lage im Tschad

Beratung in Kabul

Generalstreik in Uruguay

в/ Изразяване на преносни пространствени отнотения:

"Доверие в хуманизма"

РД 03.01 .1984
Vertrauen in den Humanismus 
"Интензификация в центъра на вниманието" РД 15.01.1984

"В името на братството"

РД 30.03 .1984

"Във века на техниката"

РД 19.01 .1984

"Двустранни договори в културната дейност" РД 17.01.1984

Intensivierung im Zentrum der Aufmerksamkeit Im Namen der Brüderlichkeit

Im Jahrhundert der Technik

Bilaterale Verträge im Bereich der kulturellen Tätigkeit

Българските публицистични заглавия, конто са по форма предложни C предлога "в" намират на синтактично и семантично равнище еквивалентен превод на немски. При превода на предлога "в" на немски трябва да се отбележи, че немският предлог "im" е едно сливане на "in dem" и че "im" се употребява много по-често, отколкото "in dem". "Im" е една форма, която чрез разговорната реч отдавна е навлязла в литературния език. Немските граматики обръщат специално внимание на факта, че в немските публицистични заглавия с "in"или "im" сравнително често се изпуска определителния член. Затова трябва да се проверява винаги, дали заглавието е напълно разбираемо и еднозначно.

4.2.4.3. Превод на предложно-именни словосъчетания с предлог 00

Българските публицистични заглавия съдържащи предлога "до" са описани в първаға глава на тази работа. Еквивалентният предлог на немски "bis" ce употребява при изразяване на същите семантични отношения, както в българския език. Примерите ще докажат, че предлогът "bis" в някои примери не е подходяш превод. C предлога "bis" в немския език употребата на Akkusativ е задължителна.

a/ предел на мястото, където достига действието:

"Стигат ли пипалата на ЦРу до Reichen die Fühler des ирландия" РД 16.01.1984 CIA bis nach Irland

6/ граница при означаване на изходната точка на отрязък от пространството, разстояние /съчетание с "от"/. напр.: 
"Живи мостове от Волга до

Рила" Рд 26.01.1986

"От "Бебреш" до мотел "Правец" -

за десет минути" Рд 06.02.1984

б/ близост

"До всеки дом" РД 10.02.1984

r/ често значението на предлога се подсилва от наречието "близо"

"Близо до трудовите хора"

Рम 16.02 .1984

"По-близо до работниците"

Рम 17.01 .1984

д/ преносни значения /определя се от по-високата абстрактност на думите, пред които стои предлогът/:

"Сътрудничество" от идеята до метала" РД 13.01.1984

"От работника до ръководителя"

РД 07.05 .1984

"Неизвестни до края"

РД 10.01 .1984

"Забава до насита"

РД 09.01 .1985
Lebende Brücken von der Wolga bis zum Rila-Gebirge Von "Bebreš" bis zum Motel "Pravec" in 10 Minuten

Für jedes haus

In unmittelbarer Nähe der Werktätigen

Näher zu den Arbeitern

4.2.4.4. Превод на предложно-именни словосъчетания с предnor $3 a$

Публицистични заглавия, които са по форма предложноименни словосъчетания с предлога "за" се превеждат на немски с предлога "für", който изисква Akkusativ. В семантично отношение "für" отговаря на българския "за" /пак се среща най-често в конструкции, които притежават финална употреба/, /Юнг 1982, стр. 862/. Но в някои случаи /примерите ще посочат това/ е възможна вариация на "für" c предлозите in, zum, zu u.a.

1. Пространствено отнотение:

Тъй като предлогът "за" притежава само финална употреба без статична, той се свързва само с определени глаголи за движение. 
"По газопровода "Уренгой - Ужгород" започнаха първите доставки за за-

падна Европа" РД 03.01.1984

Gaspipeline "Urengoj-

2. Период от време, през което се въши действието:

"От "Бебреш" до мотел "Правец" - Von "Bebreš" bis zum

за дөсет минути" РД 06.02.1984 Motel "Pravec" in 10 Min.

Забележка: При такива периоди от време, които са точно определени "на временния ос" в немския език се употребява предлога "in", т.е. известен,

10 минути

фиксиран интервал от време е налице.

a/ Пореден път на извършване на действие /събитие/:

"За първи път жена"

РД 10.02 .1984

Zum ersten Mal eine

Frau

б/ Повтаряне на действие /събитие/:

"Ouе веднъж за "Орлов мост"

РД 31.01 .1984

"Отново за двата подхода в меж-

дународната политика"

Рд 14.01 .1984

3. Изразяване на предназначение /обект - предлог- субект/:

"Cypuonnn sa tusirita merasyp

Гия" РД 10.01 .1984

"Два милиона рубли за мемориалния комплекс"

РД 18.01 .1984

"вода за полята на Плиска"

Рд 05.01 .1984

"Важно събитие за полските комунисти" РД 20.02.1984

"Пример за поколенията"

РД 11.02 .1984

"Признание за българската философия" РД 19.01.1984
Noch einmal zum Thema

"Ad lerbrücke"

Erneut $z u$ den beiden

Möglichkeiten der internationalen politik 
Тези примери доказват, че преводът на публицистичните заглавия Със "за", който са по форма предложно-именни словосъчетания, на немски се осъществява преди всичко чрез предлоra "für".

Едно изключение правят словосъчетанията от типа на втората подточка, т.е., когато се изразява период от време на действие и др. Түк българският предлог "за" не може да бъде преведен на немски с "für", а се появяват "zum" и "in". Tова положение показва, че българският "за" е по-натоварен и подесемантизиран от немския "für" и при превода трябва да се има предвид този факт.

4. 2. 4. 5. Превод на предложно-именни словосъчетания с предлог заради

Този предлог, който се среща само единично в българските публицистични заглавия, няма един единствен еквивалент на немски, а се превежда в зависимост от това, каква е връзката с действието:

"заради спокойните дни и нощи" РД 21.01 .1984

Der ruhigen Tage und /Тук се превежда с помощта на сложния предлог "wegen", който изисква Genitiv bzw. Dativ.

"Всичко заради парите"

РД 01.04 .1984

Alles wegen des Geldes

C помоита на предлога "wegen" , който изразява каузалната връзка, се осъиествява превода.

4. 2. 4. 6. Превод на предложно-именни словосъчетания със $3 a \partial$

Заглавия с предлог "зад" се срещат сравнително рядко, дори единично в българската публицистика и се превеждат с еквивалентен предлог в немския език "hinter", който изисква Dativ или Akkusativ в зависимост от действието.

$\begin{array}{lr}\text { "Голямата тояга" зад маслиненото } & \text { "Der große Schlag- } \\ \text { клонче" Рд } 14.01 .1984 & \text { stock" hinter dem } \\ & \text { Olzweig }\end{array}$


4. 2. 4. 7. Превод на предложно-именни словосъчетания с из Рядко се наблюдавт в българската публицистика заглавия с предлога "из". Примери като:

"Из анкетните карти"

Aus den Fragebögen

РД 13.01 .1984

"Из читателските писма"

Aus den Leserbriefen

РД 30.01 .1984

се превеждат на немски без трудности. При обратния превод от немски на български, който не разглеждаме тук, трябва да се обърне внимание на факта, че една голяма част от словосъчетанията с "из" - "aus", които изразяват произход на някой или нещо, се превеждат на български с "от". При словосъчетанията с предлога "от" ще срещнем пак тази особеност.

4. 2. 8. 8. Превод на предложно-именни словосъчетания с предлог кәм

Предлогът "към", който наблюдаваме в българските публицистични заглавия е изразител преди всичко на отнотение към нещо или някого.

1. Пространствено отношение

"Врати към света"

РД 03.01 .1984

"Случаен лъч към върха на

айсберга" РД 03.01.1984

"нагоре към върха"

РД 03.05 .1984

"Към сибирските реки"

Рд 13.01 .1984
Tore zur Welt

Ein zufälliqer strahl zum Gipfel des Eisberges Zum Gipfel empor

Zu den Flüssen Sibiriens

В тези примери предлогът "към" се превежда на немски със "zu + Dativ". Този предлог изразява съиото пространствено отношение, както "към" /посока към нещо/ и често zи се слива с определен член, напр. zu der ce слива, получава ce zur, аналогично на zu + dem става zum. 
2. Отнотение спрямо някого:

"Доверие към най-достойните"

Vertrauen $z u$ den Besten Рम 30.01 .1984

"Почет към паметта на Юрий

Ehre dem Andenken Juri

Андропов" Рд 15.02.1984

Andropovs

Последна почит към изтъкнатия

Letzte Ehre dem hervor-

борец РД 14.02.1984 ragenden Kämpfer

"Взискателност към всеки" Anforderungen an jeden

Рम 13.12 .1979

Примерите 2 и 3 намират в немския превод устойчиви изрази, които са безпредложни, тези фрази / в този случай "Kondolenzformeln"/ не се променят. Но в другите случаи пак наблюдаваме предлога zu + Dativ.

3. Отношение спрямо нещо:

"Противоречиво отнотение към

Ein widersp̣üuchliches Яорданско-Палестинското споразумение"

Рд 21.02 .1985 Verhältnis zum Abkom-

"Стремеж към трайно присъствие" men von Jordanien und РД 08.01 .1984 Palästina

Streben nach einer

"Интерес към книгата" dauerhaften Präsens

РД 08.01 .1984

"Вярност към идеите на маркInteresse am Buch сисма-ленинизма" Treue zu den Ideen des Рд 15.02 .1984 Marxismus-Leninismus

Рекцията на глагола streben e предлогът nach + Dativ a субстнтивът Interesse за изразяване на тези отношения изисква предлогът am + Dativ. В другите примери наблюдаваме предлога $z u+$ Dativ.

4. 2. 4. 9. Превод на публицистични заглавия, които представляват предложно-именни словосъчетания с мехду

Семантичните Функиия на българския предлог "между" се покриват напълно с тези на немския предлог zwischen + Dativ. В публицистичните заглавия наблюдаваме "между" за изразяване 
на пространствени отношения, макар че може да изрази и темпорални отношения:

1. Положение между два и повече предмета:

"Живот между куршумите"

РД 12.02 .1984

"Живот между верига и куршум"

РД 17.01 .1984
Ein Leben zwischen

Feuergefechten

Ein Leben zwischen Ket-

ten und Gefechten

2. Oтношение между две или повече лнца:

Съревнование между братя"

Рд 14.01 .1984

"Сплотеност между партия и народ"

РД 03.05 .1984

"Сделка между "Тексако" и

"Гети ойл"

РД 20.02 .1984
Ein wettstreit zwischen Brüdern

Einheit zwischen Partei und Volk

Ein Geschäft zwischen

"Texaco" und "Getty Oil"

4. 2. 4. 10. Превод на предложно-именни словосъчетания с предлог на

Предлогът "на", който е най често употребяваният предлог в българския език, притежава съответно най-много значения. Следователно неговият превод на немски ще се осъществи с помощта на различни немски предлози и различни рекции, които се употребяват в зависимост от отношението, което се изразява на български.

1. Отношение на принадлежност, притежаване:

"Апетитите на Пентагона"

РД 10.01 .1984

"Западната врата" на Москва"

РД 10.01 .1984

"Столицата на Мадагаскар"

РД 24.01 .1984

"Верен син на работническа-

та класа"

Рम 18.12 .1979
Die Gelüste des Pentagons

Das "Westtor" Moskaus

Die Hauptstadt Madagaskars

Ein aufrechter Sohn der Arbeiterklasse 
"Здрава опора на партията"

РД 05.12 .1979

"Фирмен магазин на "Серди-

ка" РД 05.12.1979

"Успехи на миньорите"

РД 12.02 .1984

"дела на комунистите"

РД 18.01 .1984

"Капризите на зимата"

РД 24.01.1984

Новото правителство на

Нигерия" РД 19.01.1984
Eine feste Stütze der Partei

Firmengeschäft des Kombinates "Serdika"

Die Erfolge der Bergleute

Taten der Kommunisten

Die Launen des winters

Die neue Regierung $\mathrm{Ni}-$ gerias

Тези примери показват, че отношението на принадлежност или притежаване, които се изразяват с помощта на предлога "на" намират техен превод на немски чрез безпредложни именни словосъчетания. Отношението на притежаване се посочва чрез рекцията на Genitiv от страна на притежателя. Наблюдаваме, предимно в говоримата реч/Umgangssprache/ конкуренция между употребата на падежната форма и предложната форма. Така например е възможно да се употребява "Die neue Regierung Nigerias" или "Die neue Regierung von Nigeria".

Но в литературния език се предпочита падежната форма. "Нови оръжия на Ескулап" Neue "Waffen" AescuРд 06.01 .1984 laps

Специално предлогът "von"ce характеризира в съвременния немски език като "Kasusersatz" - заместител на падежна форма /Хайдолф 1981, стр. 697/. Предлогът "von" изисква Dativ.

2. В заглавията често са посочени собствени имена на политици или други дейци и личности на обществено-политическия живот, информира се за тяхната дейност. Тук предлогът "на" пак посочва едно отношение на принадлежност.

"Реч на другаря Константин

Черненко"

РД 14.02 .1984

"Среша на другаря тодор
Rede des Genossen

Černenko

Treffen des Genossen 
Живков с другаря Жорж Хауи"

РД 05.01 .1984

"Решение на X. Кол"

РД 02.02 .1984

"Декларация на председателя

Ha OAE"

РД 14.01 .1984

"Поредният рекорд на Дювалие"

Рд 16.02 .1984

"Декларация на X. Шмит"

Рд 14.01.1984

"Среща на А. А. Громико С

Дж . Шулц"

Рд 19.01 .1984

"Погребението на Секу туре"

РД 01.04 .1984

"Обиколка на Робърт Хок"

РД 30.01 .1984

Заседание на "Ал Фатах"

РД 11.01 .1984
Todor Živkov mit dem Genossen George Hauyi

Entscheidung $\mathrm{H}$. Kohls

Deklaration des Vorsitzenden der VAE

Der nächste Rekord Duvalliers

Deklaration $H$. Schmidts

Treffen A. A. Gromykos mit G. Schultz

Bestattung Sekou Toures

Die Rundreise Robert Houks

Sitzung der "Al Fattah"

3. В съчетание със съществително име /или друга дума със субстантивно значение/ за изразяване на косвено допьлнение/ тъй като тук се насочва лействие, присиствува глагол, така че тези примери няма да ги причислим към безпредложно-именните групи, те са изречения, но трябва да ги представим тук за едно по-пълно разглеждане на Функциите на предлога "на" в съвременния български език/. След предлога "на" се представя името на лицето или предмета, върху който минава или е насочено действието:

"Разчита се на алпийците"

Рд 17.01 .1984

"Всички залагат на сигурHoctта

РД 22.01 .1984
Auf die Alpinisten wird gezählt

Alle setzen auf sicherheit 
"Спекулациите не отговарят

на действителността"

Рд 12.01 .1984
Die Spekulationen entsprechen nicht der wirklichkeit

При превода на немски се появява предлогът "аuf", който сигнализира в семантично отношение каузалната връзка, а от граматична гледна точка той регира /изисква/ Akkusativ или lativ, в случан, когато се извършва една целенасочена дейност или едно движение, Dativ в случай на статично състояние. Тук, в първите два примера рекцията на предлозите е Akkusativ, a в третия пример се употребява безпредложното съчетание, което ce управлява от глагола, който изисква Dativ / Юнг 1982, стр. 352, Флемиг 1981, стр. $698 /$.

\section{4. Пространствени отношения}

Тук се описват конкретни локализации, следователно ce появява предлогът "auf" с рекция на Dativ.

\footnotetext{
"на друг континент"

РД 15.01 .1984

"Светът се събира на наша земя"
}

РД 11.01 .1984

"Красотата на улицата"

РД 15.02 .1984
Auf einem anderen Kontinent

Die Welt versammelt sich auf unserer Erde

Die Schönheit auf der Straße

Но има и други варианти на превода на предлога "на", като изразител на пространствени отношения, напр.:

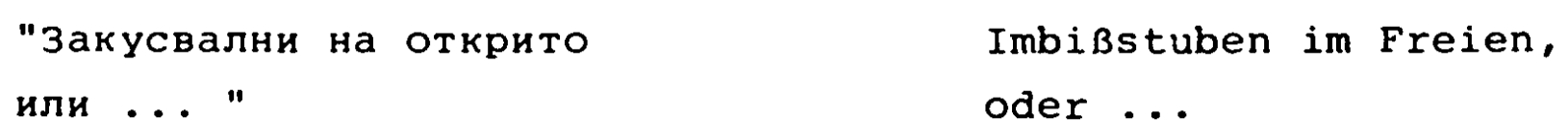

Рд 15.02 .1984

"Отглеждане на открито" Aufzucht im Freien

Рд 16.02 .1984

Тези примери посочват, че предлогът "на" в тези примери, които описват състояние /и за тях се пита "къде"/ се превежда на немски c im + Dativ.

Предлогът "на", който е най-натовареният предлог в съвременния български език се появява и в публицистичните загла- 
вия с няколко функции, които намират обаче /задължително/ за всяка определена Функция един друг предлог или една друга рекция на немски.

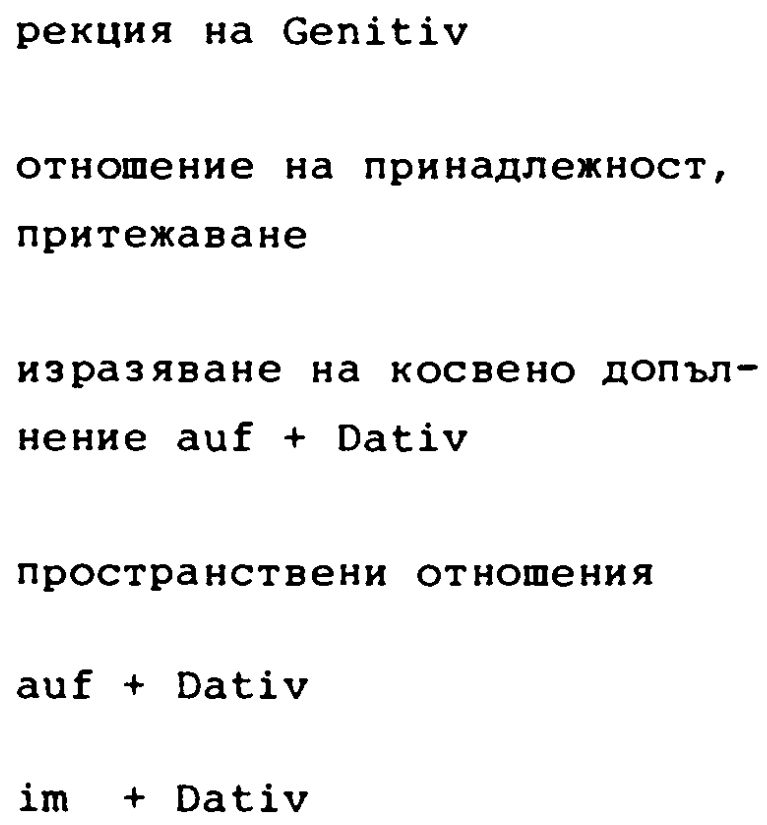

Тези примери не изчерпват цялата семантична натовареност на българския предлог "на", тъй като тук се ориентираме само върху публицистични заглавия, но и в тази област се документира многообразието на този предлог, който често пъти представлява проблем за преводача.

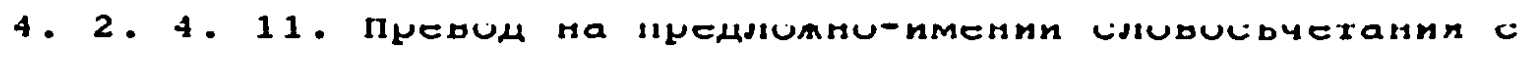
предлога кад

В българските публицистични заглавия наблюдаваме предлогът "над" повече в статична употреба. Ha немски той ще се преведе с предлога über + Dativ или Akkusativ, пак в зависимост от това, дали се извършва целенасочена дейност или движение /Akkusativ/ или се описва състояние или място /Dativ/. "Силни бури над Северна Starke stürme über NordЕвропа" europa

РД 15.01 .1984 
i. 2. 4. 12. Превод на публицистични заглавия, които представляват предложно-именни словосъчетания с предлога оm

Предлогът "от", който притежава няколко семантични функции на български, които ще бъдат разгледани сега, намира следователно няколко варианта на превода на немски:

1. ИзходнОСт :

"Вода от извора"

Quellwasser

Рд 22.01 .1984

"трансплантацията излиза от

Die Transplantation

лабораториите"

РД 11.01 .1984

geht von den Laboratorien aus

Този вид словосъчетания, както ще покажат и следващите примери, често се превежда на немски с композитум. Това явление се разглежда и от сравнителното езикознание.

2. Отдалечаване:

"документи, предадени от

Dokumente, aus Entferразстояние nung eingereicht

РД 10.01 .1984

"Без дистанция от проблемите" Ohne Distanz von den

РД 10.01 .1984

Problemen

3. Начален предел във времето:

"От зората на кинематографията"

Рд 13.01 .1984

Vom Sonnenaufgang der

Kinematographie

4. Партитвност/отделяне на част от цяло/:

"Страници от натата национална

Seiten aus unserer Geистория" schichte

РД 08.01 .1984

"Три от седем"

HM 28.11 .1979

"Първите от отряд "Георги

Die Ersten der Truppe

Бенковски"

Georgi Benkovskis

РД 01.04 .1984 
5. Производители на действието:

"жалба от адвокатите на

Антонов"

РД 17.01 .1984

"Дарение от художници"

РД 04.01 .1984

6. Местопроизход:

"Политически пътепис от

Аржентина"

РД 08.01 .1984

"Гости от близки н От

далечни страни"

Рд 03.01 .1984

Машини От ССCP"

РД 05.01 .1984

"Сигнали от невидимата

действителност"

РД 24.01 .1984

"Мъже от Балкана"

Рд 01.04 .1988

"Свеж полъх от Тракия"

РД 21.02 .1985

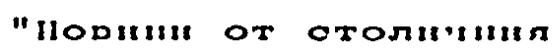

зоопарк"

РД 15.02 .1984

"Редове от редакцион-

ната поща"

РД 15.02 .1984

"Новости от филателията"

РД 03.05 .1984

"Туристи от квартала"

Рд 26.01 .1984
Berufung von den Anwälten Antonovs

Eine Schenkung von

Künstlern

Politische Reisebeschreibung von Argentinien

Gäste von nah und fern

Maschinen aus der UdSSR

Signale aus der unsichtbaren wirklichkeit

Männer vom Balkan

Ein frischer Hauch aus Thrakien

Nouigroiton aus dom Tinrpark der Hauptstadt

Zeilen aus der Leserpost

Neuheiten aus der Philatelie

Touristen aus dem Wohnviertel

7. Определение на качество на определяемия обект /посочва се материалният произход или веществен състав/: 
"изделия от дърволит"

РД 08.05 .1988

"нови продукти от птиче месо"

РД 05.01 .1984

Erzeugnisse aus steinholz

Neue Produkte aus Geflügelfleisch

8. Източник за получаване на нещо:

"Добри резултати от все-

Gute Resultate von der отдайната и упорита раbeständigen und aufopбота на трудещите се през ferungsvollen Arbeit der миналата година"

Рд 17.01 .1984 Werktätigen im vergangenen Jahr

Предлогът "от", който е натоварен с много семантични Функции и в публицистичните заглавия, когато се касае за изразяване на произход, в най-широкия смисъл на думата/ локален, каузален и модален/, той се превежда на немски с aus + Dativ, a когато ce изразява една партитивност /отделяне/, било то в локално, темпорално или каузално отношение, наблюдаваме употребата на предлога von + Dativ. /Срв.: Иванка е от София - Ivanka ist aus Sofia /локално отнопение/. Писмото е от нея - Der Brief ist von ihr /партициално отношение/, /Флемнг 1981, стр. $697 /$.

4. 2. 4. 13. Превод на безпредложно-именни словосъчетания с предлог no

Предлогът "по", който изразява пространствени, темпорални и абстрактни отношения, намира различни начини на превода на немски.

1. Пространствени отношения:

"Българската художествена култу-

Bulgarische Kunst in

ра по света" der ganzen welt unter-

Рд 20.01 .1984 wegs

"Услуги по месторабота"

Dienstleistungen am

Рд 05.01 .1988

Arbeitsplatz 
"Българската архитектура по света"
Bulgarische Kunst im Ausland

Рम 20.01 .1984

2. Посока на действие: /действието има съцата посока или следва нешо/

"По маршрутите на братството"

РД 03.01 .1984

"По линията на най-голямото

съпротивление"

Рд 03.05.1984

"Твърдо и уверено по изпита-

ния път"

РД 10.02 .1984

"Киното по пътя на прогреса"

Рд 10.02.1984

"По следите на крадците"

Рд 18.01.1984

"По следите на нашата критика"

РД 06.01 .1984

3. Основание, съответсвие /по-според/

"По стара традиция"

Рд 17.01.1984

"llo законите на интернационализма"

Рд 17.01.1984

"По повод на публикуваното"

Рд 15.02 .1984

4. Област на някаква дейност:

"Партийно събрание по въпроси на качеството"

Рд 14.01 .1985

"Разговори по кипърския

въпрос"

Рम 11.01 .1984
Nach alter Tradition

Auf dem wege der Brüderschaft

Auf dem wege des größ-

ten Widerstandes

Fest und sicher auf dem erprobten weg

Das Kino auf dem Wege

des Fortschritts

Auf den Spuren der Diebe

Auf den Spuren unserer Kritik

Nach den besetzen des Internationalismus

Aus Anlaß der Veröffentlichung

Parteiversammlung $\mathrm{zu}$

Fragen der Qualität

Gespräche zur 2ypernFrage 
"Разговор по широк кръг

въпроси"

РД 06.02 .1984

"Размишления по чита-

телски писма"

Рд 04.12 .1984
Gespräche zu einem breiten Themenkreis

Gedanken zu Leserbriefen

Четирите семантични отношения, които изразява предлоГът "по" в публицистичните заглавия, намират четири различни предлога в превода им на немски, в зависимост от отноmението, което се изразява. Немските предлози с техните съответни рекция са специфични за всяка посочена Функция, която се изпълнява от предлога "по".

$\begin{array}{ll} & \text { пространстени отношения } \\ & \text { in + Dativ } \\ & \text { am + Dativ } \\ \text { по } & \text { посока на действие } \\ & \text { auf + Dativ } \\ & \text { основание } \\ & \text { съответсвие } \\ & \text { nach + Dativ } \\ & \text { област на дейност } \\ & \text { zu + Dativ }\end{array}$

4. 2. 4. 14. Превод на предложно-именни словосъчетания С предлог nод

Предлогът "под", който в българските публицистични заглавия се употребява за посочване на "място", където се извършва или е насочено действие, или изяснява обстоятелства, не изразява традиционната му натовареност като пространствен предлог. Той намира еквивалентен превод на немски чрез предлога unter с рекция на Dativ или Akkusativ в зависимост от това, дали се касае за целенасочено действие /Akkusativ/ 
:іли статично положение /Dativ/, /Юнг, 1982, стр. 353/, напр.:

"Слънце под покрив"

Sonne unterm Dach

РД 18.01 .1984

"Под ръководството на ком-

Unter der Leitung des

сомолиите"

Komsomols

РД 06.02 .1984

"Под закрилата на цРу"

Unter dem Schutz des

РД 11.01 .1984

CIA

"Под чужд ритъм"

Unter fremdem Rhyth-

Рд 26.01 .1984

mus

4. 2. 4. 15. Превод на предложно-именни словосъчетания С предлог пред

Предлогът "пред", който наблюдаваме в българските публицистични заглавия в следните изброени семантични Функции, се првежда на немски с предлога "vor", който изпълнява същиre семантични функции, рекцията на "vor" пак e Dativ или Akkusativ, както при предлогът "под" - "unter" и други.

1. Място от гледна точка на лицето: /конкркетно/

"Пред хималайските върхове"

РД 30.03 .1984

/преносно/

"Uтговорни задачи пред младежта"

РД 12.01 .1984

"Малкотърновската селина

система пред прага на

ускорено социално-икономи-

ческо развитие"

РД 17.01 .1984

"Най-драматичното остана

зад нас, най-трудното е

пред нас"

РД 01.04 .1984
Vor den Gipfeln des $\mathrm{Hi-}$ malaja

Verantwortungsvolle Autgaben vor der Jugend

Der Gemeindeverband von Malkotârnovo steht vor einer raschen sozialökonomischen Entwicklung

Das Dramatischste liegt hinter uns, das Schwierigste liegt vor uns 
2. Преходност по време:

"Пред изгрев"

РД 13.01 .1984

"Пред старта"

РД 08.05 .1984

"идеологическата борба

пред прага на 80-те го-

дини "

Рд 13.12 .1984
Vor dem Sonnenaufgang

Vor dem start

Der ideologische Kampf an der Schwelle der Achtziger Jahre

3. По отношение на кого или що /непряк обект/ ce проявява качество, чувство или се извършва действие:

"Широки перспективи пред

братското взаимодеяствие"

РД 18.01 .1984

"Поклон пред подвига"

Рд 16.01 .1984
Große Perspektiven für die brüderliche Zusammenarbeit

Achtung vor der Heldentat

4. 2. 4. 16. Превод на предложно-именни словосъчетания с предлог през

Намира различни начини на превода на немски, в зависимост от семантичната функция на предлога в заглавието.

1. Пространствени отнотения :

"През завоите или по най-

прекия пвт"

РД 17.01 .1984

"През три океана"

РД 13.01 .1984

2. Темпорални отнотения:

"Икономиката през януари"

РД 02.02 .1984

"През зимните дни"

РД 07.01 .1984

"Софийски адреси през 1984"

Рд 17.01 .1984
Durch den kurvenreichen oder auf dem nächsten Weg

Durch drei Ozeane
Die Okonomie im Januar

In den wintertagen

Sofioter Adressen 1984 
"Унгарската промипленост

през $1984 "$

РД 20.01 .1984

"на почивка през ваканцията"

Рд 03.01 .1984
Die ungarische Industrie 1984

In den Ferien zur Erholung

Когато се касае за пространствено отношение, "през" намира най-точния превод на немски чрез предлога durch + Akkusativ. A при превода на предлога "през" като показател на темпорални отнотения се употребяват немските предлози "im" или "in", които сигнализират в тези случаи темпорални обстоятелства /въпрос: Кога?, До кога?/, /Онг, 1982, стр. 347/. Когато се съобщават годишни числа в немските публицистични заглавия не е задължително да се употребява предлог или да се пише: "Die ungarische Industrie im Jahre 1984", а посочването на самото число в такъв случай е напълно достатъчно: "Die ungarische Industrie $1984 "$.

4. 2. 4. 17. Превод на предложно-именни словосъчетания с предлог при

Той е основен предлог за изразяване на пространствено отнотение в статична и финална употреба. Неговият превод на

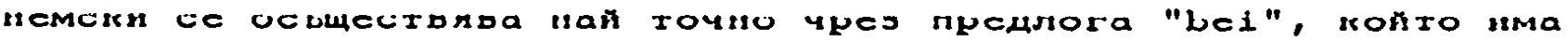
рекция на Dativ.

В публицистичните заглавия наблюдаваме предлогът "при" за изразяване на следните отнотения:

1. Непосредствена близост:

"Младостта при белите бобини"

Die Jugend an den

Рд 11.01 .1984 weiBen Spulen

2. Обстоятелства, придружаващи действие или явление:

"Научен подход при подбора

на търговските работници"

РД 10.01 .1984

"Строителството при нула

градуса" Рд 11.01.1984
Wissenschaftiches Herangehen bei der Auswahl der Verkäufer Bauarbeiten bei Null Grad 
"влиянието на климата при

бронхиална астма"

Рд 16.11 .1979
Der Einfluß des Klimas bei Bronchialasthma

4. 2. 4. 18. Превод на предложно-именни словосъчетания с предлог $c$

В съвременния български език предлогът "с" е изразител главно на социативни отношения. Той се превежда на немски с предлога mit + Dativ, който изразява същото семантично отнотение. В публицистичните заглавия наблюдаваме често предложноименни словосъчетания с предлога "c" като изразяват следните Отнотения :

1. Социативни отнотения, взаимодействие:
"икономическа помощ с поли-
Wirtschaftshilfe mit тически условия" politischen Bedingun-
Рд 09.01 .1984 gen
"икономическа безизходица с Wirtschaftliche Ausweg- политически отражения" losigkeit mit politi- РД 12.01 .1984 schen Auswirkungen

1a/ Социативни отнотения, които приписват свойство и качество на предмет или явление:

"Дейност с високи цели"

РД 22.01.1984

"Теория с гарантирано ка-

чество"

РД 06.02 .1984

"Кампания с важно значение"

РД 11.01 .1984

"Политически съюз с наднациоални пълномощия"

Рд 15.01 .1984

2. Средство, оръдие на действие: "Политика с боксови ръкавици"

Рд 02.01 .1984
Tätigkeit mit hoher Zielstellung

Theorie mit garantierter Qualität

Kampagne mit großer Bedeutung Politisches Bündnis mit übergreifenden Vollmachten

Politik mit Boxhandschuhen 
"Oпасни размахвания С

"Дамоклевия меч"

HM 28.11.1979

"C конска карета към

миналото"

Рд 15.02 .1984

3. Снабденост:

"Еленът с червената

лента"

РД 15.01 .1984

"Българските сортове с

български имена"

Рд 16.01 .1984

"Автобуси с втечнен

газ"

РД 30.03 .1984

"Сладкиш с салмонели"

Рд 07.05 .1984

4. Обектни отношения:

"Диалози с трудовите

xоpa"

Рд 10.01 .1984

"Всеки ден с преизпълнен

график"

Рम 18.12 .1979

"Вечери С творчеството

на яворов"

РД 13.01 .1984

"Cpeщa c "академичната"

Фотография"

Рम 26.01 .1984

"Cpeща с поезията на

Евтушенко"

Рд 06.02 .1984
Gefährliche Drohungen mit dem "Damok lesschwert"

Mit der Pferdekutsche in

die Vergangenheit

Der Hirsch mit dem roten Halsband

Bulgarische sorten mit bulgarischen Namen

Busse mit Flüssiggas

Gebäck mit Salmonellen

Dialoge mit den Werktätigen

Jeden Tag mit überertü 1 tem Plan

Abende mit dem IVerk Javorovs

Treffen mit der "akademischen Fotographie"

Begegnungen mit der Poesie Evtušenkos 
"Солидарност с Никарагуа"

РД 03.04 .1984
Solidarität mit Nikaragua

5. Често срещаме в българската публицистика заглавия от типа на "предлог "с" + прилагателно име + съществително име:

"С младежки ентузиазъм"

РД 09.01 .1984

"С взаимни усилия"

РД 18.01 .1984

"Със собствени сили"

Рд 19.01 .1984

"С комунистическа убедеHOCT"

РД 26.01 .1984

"С пълни сили"

РД 08.05 .1984

"С обновена база"

РД 21.01.1984

"С ускорени темпове"

РД 07.01 .1984

"С отлично качество"

РД 20.02 .1984

"С удвоена гаранция"

Рम 26.01 .1984

"С повишени качествени

показатели"

Рд 30.03 .1984
Mit juqendlichem Enthusiasmus

Mit gemeinsamen Anstrengungen

Mit den eigenen Kräften

Mit kommunistischer Uberzeugung

Mit voller Kraft

Mit erneuerter Basis

Mit beschleunigtem Tempo

Mit ausgezeichneter Qualität

Mit doppelter Garantie

Mit verbesserter ọulität

От всиски тези примери с различните Функции на предлога "c" се установява, че той се превежда на немски само с предлога "mit".

4. 2. 2. 19. Превод на предложно-именни словосъчетания с предлor cred

Публицистични заглавия с предлога "след" наблюдаваме срав нително рядко, предлогът "след" изразява темпорална последовате 
ност или непрекъснатост /темпорална и локална/.

"След победата"

Nach dem Sieg

Рд 15.02 .1984

"Град след град"

Eine stadt nach der anderen

Рд 24.01 .1984

Предлогът "след" се превежда на немски с предлога "nach", който има рекция на Dativ.

4. 2. 4. 20. Превод на предложно-именни словосъчетания с предлог cped

Изразява пространствено значение, близо до конкретното значение на съществителното "среда", от което той произлиза. на немски този предлог се превежда по следния начин:

1. Изразяване на конкретно пространствено значение: "Сред" се превежда с предлога "im" или in + Dativ.

/обозначава се място/

"Завод сред бялата степ"

Eine Fabrik in der weißen

Рд 06.01 .1984

Steppe

"Метеоролози сред ледовете" Meteorologen in der EisРД 12.01 .1984 wuis te

2. Изразяване на абстрактно пространствено отнопение: "Грел" в такив сличай се прережла на немски с преллora unter + Dativ.

"Винаги сред първите"

Immer unter den Ersten

HM 24.10.1979

"Сред най-добрите"

Unter den Besten

РД 08.05 .1984

"Гняв и възмущение сред

Empörung und Entrüstung

милионите"

unter Millionen Menschen

Рд 19.12 .1979

4. 2. 4. 21. Превод на предложно-именни словосъчетания с предлог срещу

Предлогът "срещу" запазва своите употреби отсенки от 
своето първоначално значение: протоивоположно движение или положение спрямо предмета. В българските публицистични заглавия "срещу" изразява най-често противопоставяне, враждебно отношение или подобни положения. Той се превежда на немски с предлога gegen + Akkusativ.

"Успешня действия срещу

aгpecopa"

РД 11.01 .1984

"Груба провокация срещу

никарагуа"

РД 26.01 .1984

"Възмущение срещу насилието"

РД 12.01 .1984

"Обвинителен акт срещу

Рейгеновата политика"

РД 20.01 .1984

"Протест срещу намесата"

РД 02.02 .1984

"Мерки срещу нападенията"

Рд 07.01 .1984

"Акт срещу разума"

Рд 18.12 .1979

"Ракети срещу разведря-

ването"

Рд 19.12 .1979

"Мерки срещу терористическите действия"

Рम 18.12 .1979

"Борба с всички сили срещу ядрената заплаха"

Рम 14.01.1984
Erfolgreiche Aktionen gegegen den Agressor

Grobe Provokation gegen Nikaragua

Empörung gegen die Gewalt Anklageakt gegen die Reagan-Politik

Protest gegen die Einmischung

Maßnahmen gegen Uberfälle

Akt gegen die Vernunft

Raketen gegen Entspannung

Maßnahmen gegen TerrorAktionen

Kampf mit allen Mitteln gegen atomare Bedrohung 
4. 3. ПРЕВОД НА БЪЛГАРСКИ ПУБЛИЦИСТИЧНИ ЗАГЛАВИЯ, КОИТО ПРЕДСТАВЛЯВАТ ДА-ФОРМИ ОТ БЪЛГАРСКИ НА НЕМСКИ

Теоретични уводни бележки

Една отличителна черта на южнославянските езици е употребата на да-формите. Заради тази особеност В. Ягич /1913/ е означил тези езици като "да-езици". Да-формите в съвременния български език заслужават действително голям интерес, защото те са едно езиково изразно средство с широка семантична гама и висока честота на употреба в разговорната реч и в книжовния език. Преди да разгледаме съвременното състояние и преди всичко употребата на да-формите в публицистичните заглавия, трябва да обърнем внимание на някои исторически моменти в развоя на тази Форма, това ще бъде полезно и за превода. В съвременния български език на мястото на синтетичните старобългарски инфинитивни форми се употребяват аналитични конструкция, състоящи се от да + лична глаголна формa /verbum finitum/ - характерна черта на аналитизма на съвременния български език, която се отличава не само от останалите славянски езици, но и от редица други индоевропейски езици /ГСБКЕ, тОм II, стр. $35 /$.

Определена конкуренция в употребата на императива и на да-формите се наблюдава още от старобългарската епоха. Оие тогава простата императивна форма за 1. л. мн. ч., която не съществува днес, е изместена от съответната да-Форма. Нещо повече, в старобългарски частицата "да" се поставя за засилване пред простите императивни форми /Курц 1968, стр. 127/, Факт, който говори за голямо сближаване на двата вида форми, образувани от сегатна основа /ницолова 1984, стр. 132/. В РСБКЕ и В ГСО̆КЕ е посочено, колКо ФУнкция изпълняват да-формите и едновременно колко много семантични оттенъци могат да бъдат изразени чрез тях. Срещаме ги в изказвания и изречения, за изразяване на подбуда или покана да се извършва действие, при въпроси за изразяване на съмнение, несигурност, неувереност или колебание за нещо, в подбудителните изрече- 
ния или за изразяване на заповед или забрана. Срещаме да-формите също така в изреченията за изразяване на желание или пожелание за осъществяване на някакво действие, както и във възклицателните изречения.

В публицистичните заглавия не се срещат всички от изброените варианти на да-формите, а главно те се употребяват с цел да изразяват категорична подкана или подбуда за действие или пожелание.

Маслов /1982, стр. 287/ различава при да-конструкциите /конюнктив/ един независим тип, т.е.конюнктивът се употребява като самостоятелно глаголно сказуемо, напр.: "Да вървим!" и един зависим тип, където конюнктивът е подчинен на друг глагол, подобно на неличните глаголни форми от типа на: "Продължавахме да вървим."

Но терминът "конюнктив", както го представи Маслов /1982/ трябва да приемем с известна предпазливост. Напълно оправдани и правилни са забележките на Генадиева-мутафчиева /1970/, Минчева /1968/и Попов /1973 стр. 114/ пише: "В съвременния български е явна тенденцията по аналитичен път, чрез да-конструкция, да се изразяват модални отнощения, изразявани чрез Формите на специална глаголна категория, а именно чрез кононктив. Да-конструкцията обаче има по-широк обхват от конюнктива. Като застъпник на стария инфинитив и на някои причастни Форми тя може да изразява и известна неопределеност на действието, близо до изразяваната чрез инфинитив. Също така да-консрукцията може да съдържа и реално действие, изразявано чрез индикатив."

Самите примери и превода им на немски ще докажат, че това становище е правилно.

Като се основаваме на възгледите на хайдолф, Флемиг, Моч /1981/, на Шмит/1981/, Вундерлих /1975/ и Попов /1974/, откриваме както в немския език, който е синтетичен, така и в българския език, който е аналитичен, явления, свързани с езиковата икономия, с максимално съкращение на израза, което води в някон случаи към номинализация. Общоизвестно е, че в публицистиката, особено в заглавията на най-важните материали, се 
използуват много често именни изречения, което води до монотонност и паблон. В тези случаи има възможност именните изречения да се заменят с глаголни, за да се постигне близост с разговорната реч, да стане изказът по-динамичен. Наблюденията, които севпдят от 1979г. насам показват, че има тенденция към увеличаване на употребата на да-конструкцинте в публицистичните заглавия. Срв. таблицата:

\begin{tabular}{|c|c|c|c|}
\hline Година & $\begin{array}{l}\text { Граматична структура } \\
\text { на заглавията }\end{array}$ & $\begin{array}{l}\text { В българските } \\
\text { заглавия в } 8\end{array}$ & $\begin{array}{l}\text { В немските } \\
\text { заглавия в }\end{array}$ \\
\hline & $\begin{array}{l}\text { Субстантивни слово- } \\
\text { съчетания }\end{array}$ & 72,80 & 52,20 \\
\hline \multirow[t]{3}{*}{1979} & $\begin{array}{l}\text { Незавършени и непъл- } \\
\text { ни синтактични кон- } \\
\text { струкция, нзречения }\end{array}$ & 25,90 & 34,60 \\
\hline & Да-конструкции & 100,00 & $\begin{array}{l}\text { Глаголни, } \\
\text { причастии, } \\
\text { инФинитивни } \\
\text { констр. и } \\
\text { др. } \\
13,20 \\
100,00\end{array}$ \\
\hline & $\begin{array}{l}\text { Субстантивни слово- } \\
\text { Съчетания }\end{array}$ & 69,50 & 49,00 \\
\hline \multirow[t]{2}{*}{1984} & $\begin{array}{l}\text { Ноэаогршсн, испил- } \\
\text { ни синтактични кон- } \\
\text { струкцин, изречения }\end{array}$ & 29,06 & 31,00 \\
\hline & Да-конструкции & 2,44 & $\begin{array}{l}\text { Глаголни, } \\
\text { причастии и } \\
\text { инФинитивни } \\
\text { конструкции } \\
\text { др. } \\
12,00\end{array}$ \\
\hline Всичко: & & 100,00 & 100,00 \\
\hline
\end{tabular}

Глаголът в да-Формите в съвременния български език е във всички времена и числа.

В публицистичните заглавия се срещат да-формите за се- 
гашно време в следните лица и числа:

1. В 1 л. ед. ч. да-формите не се срещат в публицистичните заглавия. Това може да се обясни с Факта, че в 1 л. ед. 4. липсва признакът масовост/Костомаров 1971/. който е основен за публицистичните заглавия.

Първоличната форма в множествено число играе важна роля в българската публицистика. Чрез нея много ясно се изразява призивния характер на публичистичните заглавия. Както споменахме вече, съществува конкуренция на императива с да-формите Журналистът с определено комуникативно намерение предпочита да-формата в 1 л. мн. ч. пред императивната форма от 2 л. мн. 4. за да изрази с да-формата прнобщаване към множеството читатели, към конто се отправя поканата, а не да се дистанцира от тях, както е при императивната форма. При това с даформата за 1 л. мн. ч. пишещият се сближава с читателя. Неведнъж е подчертано какво голямо значение има 1 л. мн. ч. за българската разговорна реч/Попов 1978, стр. $445 /$. Следните примери ще илюстрират казаното по-горе:

"Да опазим околната среда!"

РД 24.01 .1985

/Вм. "Опазвайте околната среда!" /

"да търсим, да изучаваме"

Рд 04.02 .1985

/Вм. "Търсете, изучавайте!"/

"да работим от сърце за

благото на всички"

Рम 16.12 .1979

/Вм. "Работете от сърие за

благото на всички!"/

"Да видим своето място и роля"

Рम 28.01 .1985

/Вм. "Вижте своето място и роля!" /
Schützen wir die Umwelt (oder)

Die Umwelt schützen

Suchen und Forschen

Unsere Arbeit für das wohl des ganzen Volkes 
При първоличните да-форми за мн. число в заглавията не можем да различаваме заканата за близки и далечни действия, както например в разговорната реч. В заглавията се изразява заканата за действия, които са:
а) повеля на днешния ден,
6/ също и подкана за повтарящи се и по-далечни действия. например:

"Да пестим енергията!"

Energie sparen!

РД 24.01 .1985

"Да излезем от омагьо-

Den Teufelskreis durch-

сания кръг!" brechen!

Рд 24.03 .1985

"да вземем повече от

Die Ernteerträge steiполето!" gern!

РД 12.06 .1985

"да опазим реколтата от Die Ernte vor Brandgeпожари!" fahr schützen!

РД 05.06 .1985

"да узнаваме човека" Den Menschen kennenlerHM 13.12 .1979 nen

"Да запазим земята!" Die Erde bewahren!

РД 14.01 .1984

2. При ртороличиито да-коиструкиии п рәтларията иабпидаваме най-силната конкуренция с императивните Форми. Точно при тези второлични Форми в единствено число често наблюдаваме, че те заместват стария инфинитив /мирчев 1937/. Примерите онагледяват това:

"да живееш, значи да се

Leben heiBt kämpfen

бориш"

HM 09.02 .1985

"Да обичаm ближния, значи

Nächstenliebe heißt, am

да се включиш в революцията" revolutionären Kampf

HM 02.03 .1985

teilzunehmen

"Да отговориш с дела"

Mit Taten antworten

Рम 11.01 .1985 
"Да нарисуваш мира"

Den Frieden malen

Рд 21.02 .1985

Всички тези да-Форми се превеждат на немски чрез инфинитивни Форми. Второлични да-форми в мн. число не се наблюдават. Това се дължи вероятно на факта, че те са израз на пряка подкана и точно това журналистът иска да избегне.

3. Третоличните да-Форми в единствено число се използуват за маркиране на абсолютни действия, те са с повторителен, с обичаен характер. Най-често те са глаголи в страдателно-безличен залог.

"Да се носи отговорност!

Die Verantwortung tragen

Рд 30.01 .1985

"Да се умножава ежектът!"

Den Nutzeffekt steigern!

РД 06.01 .1985

"Да се роди музика"

Musik schaffen

Рд 26.02 .1985

Тук не се конкретизира вършителят, тъй като авторът /журналистът/ иска да възбуди любопитството на читателя като посочва само обекта или резултата от действието.

В 3 л. мн. ч. да формите са рядко явление, напр.: "да се подобрят нормаDie Normvorschriften тивните документи" verbessern

РД 20.02 .1984

"да виждат хубавото"

Das Schöne sehen

РД 16.01 .1985

При тези заглавия с третолични да-Форми в единствено и множествено число наблюдаваме оптативен характер. Когато липсва удивителният знак, заглавието дори може да затрудни читателя как да го възприеме, като пожелание или като препоръка за действие. Когато има удивителен знак, заглавията се разбират вече като лека полбуда. За превода на немски на тази група най-точна и най-подходяща е инфинитивната конструкция, както се вижда ясно от тук посочените заглавия.

4. В заглавията с отрицателни императивни форми в страдателно-безличен залог да-Формите поради неконкретизирането на вършителя звучат много по-меко от императивните форми: 
"Да не се спира до дуNicht nur darüber reden мara"

Рд 07.05 .1985

/вм.: Не ce спирайте

до думата/

"Да не се робува на параKeine Paragraphensklaverei графа"

РД 02.02 .1984

/вм.: Не се робувайте

на параграфа/

Тук не се изразява забрана, а по-скоро една препоръка за извършване на действието.

5. Желателните /оптативните/ да-форми в публицистичните заглавия са по-слабо емоционални от съответните да-форми в разговорната реч и белетристиката. Общи пожелания се изразяват с примери като:

"Сурва, сурва година -

да е весела, щастлива!"

Рд 01.01 .1984

"Да е спорна и плодоносна!"

РД 01.01 .1984

"да бъде плодородна" Рम 01.01 .1984

Други заглавия с желателен характер се свързват с предстоящи обществено-политически събития като:

"да бъде начало на

(Der) Beginn einer guten Traдобра традиция" dition (ist gemacht)

HM 19.02 .1985

"да бъдем добри стопани"

РД 15.03 .1985

"да бъдем отбор на заслужени победи" HM 12.02 .1985
Ein frohes und glückliches neues Jahr!

Ein fruchtbares neues Jahr!

В предната група превеждахме с инфинитив на немски, а 
cera ce появява вече и модалния глагол "wollen" при превода на тази група.

6. Едно много интересно явление в българския печат е използуването на на да-форми в страдателен залог / със страдателно причастие/ в заглавия като:

"Да бъдат спрени агресивните SchluB mit den Agresдействия срещу Виетнам" sionshandlungen gegen РД 03.05 .1984 Vietnam!

"да бъде победена опасWeg mit der Bedrohung ността от ядрена катаст poфa" einer atomaren KataР Д 27.03 .1985 strophe!

Тези примери в страдателния залог с оптативен характер се превеждат на немски с номинални, безглаголни конструкция.

Да-формите в разгледаните групи се срешат вече по-често в публицистичните заглавия и заслужават внимание не само от граматична и стилистична гледна точка, но и от гледната точка на превода им на чужд език. При публицистичните заглавия с да-Форми не може да се предложи един единствен модел за превод на немски, поради тяхното семантично разнообразие. Като възможни варианти можем да посочим:

a/ глаголни и безглаголни варианти,

б/ варианти с модални глаголи.

При превода на публицистичните заглавия с да-форми от български на немски е необходимо да се разграничават граматичните от семантичните явления при изследването на един аналитичен език като българския и да не се търси винаги граматично и семантично единство между синтетични и аналитични Форми и между граматичните средства на аналитични и синтетични езичи. 
4. 4. ПРЕВОД НА НЕПЪЛНИ И НЕЗАВЪРШЕНИ СИНТАКТИЧНИ КОГСТРУКЦИИ В ПУБЛИЦИСТИЧНИ ЗАГЛАВИЯ

4. 4. 1. Превод на публицистични заглавия с многоточие Публицистичните заглавия с многоточие бихме могли да разпределим от граматична гледна точка и от синтактичен аспект в следните групи:

a/ безпредложно-именни словосъчетания с многоточчне,

б/ предложно-именни словосъчетания с многоточие,

в/ елиптични конструкции с многоточие,

r/ изречения с многоточие.

Но това разпределение не може да бъде единствено, когато искаме да преведем заглавия от български на немски и в никакъв случай не трябва да очакваме или да целим на немски същата конструкция да се получи, защото особено при този вид заглавия граматично-структурното и семантичното равнище са много тясно свързани. Като tertium comparationis имаме предвид преди всичко семантичното равнище на заглавието. Заглавия с многоточие и в немския език са един похват за задълбочаване на психологическата обрисовка и усилване на емоционалния ефект.

Видове публицистични заглавия с многоточие:

1. Повтарят се изрази /най-често съществителни имена/ с целта да се изразява, че те са многобройни, повтаряши се: "Години, години ..." Jahre, Jahre ...

Рд 13.01 .1984

би било несполучлив превод, когато се има предвид узуалната предложна конструкция "Jahre um Jahre" като превод за това българско заглавие.

"Класация, класация ..." Klassierungen, KlassierunРД 02.01 .1984 gen

би могло да остане като превод, тъй като в статията се изброяват само класации .

Често се употребяват конструкиия с многоточие, за да се постигне един определен психологически ефект, да се възбуди интереса на читателя. В семантично отношение двете части на 
заглавието, които са разделени чрез многоточието представляват едно семантично несъответсвие, тяхната съпоставка изненадва читателя, изразът завършва след многоточието с неочаквана или изненадваща кулминация. Напр.:

Безглаголни предложно-именни словосъчетания "Tеатър ... без суфльор" Theater ... ohne Souffleur РД 06.02 .1984

/Известно е, че във всеки театър и за всяко представление е необходим суфльор, тогава тук се касае за необикновен теаrop./

"Бюро за ... разсеяните" Ein Büro für ... Zerstreute РД 15.02 .1984

/Има бюро за информация и справки и др., но това е необикновено./

"Стротелството в ... Bauarbeiten in ... den Wolоблаците" ken

Рд 20.01. 1984

/Строителството се извърпва обикновено на земята./

"Производители на ... Erzeuger von ... Gesundheit здраве"

Рд 30.01 .1984

/Обикновено се произвеждат материални продукти./

"Корабостронтелят от ... Schiffsbauer aus .. Gabrovo Габрово"

РД 22.01 .1984

/Предполага се, че корабостроители произхождат от крайбрежието или прнстанищен град./

"Сгради от ... ламарнна" Häuser aus .. Wellblech

РД 12.01 .1984

/Сгради се строят от камени или бетон./

"Спасение чрез ... Rettung durch ... Selbstbeсамонзмама" trug

РД 12.01 .1984

/на всеки е известно, че самоизмамата не е никакво спасение./ изречения с многоточие

"С музика става ... пум" Die Musik wird zu ... Lärm 
РД 06.02 .1984

"Продава се ... смърт"

Verkauft wird auch ...

РД 07.05 .1984

Tod

"Докторе, помогни ми

Doktor, hilf mir, ...

или ... ще те наругая!"

sonst kriegst du was $\mathrm{zu}$

РД 10.02 .1984

hören!

"това не е само ... mera"

Das ist mehr als ein ...

РД 22.01 .1984

Scherz

На този вид заглавия можем да припишем дори провокиращи черти в комуникативно-прагматичен план. При превода на заглавията от този тип като tertium comparationis ни служи семантичният компонент, понякога /Както се вижда от самите примери/ се получава един по структура и семантика еквивалентен превод, но това не може да бъде нормата за такъв превод.

Заглавия с многоточие, които изразяват незавършеност на мисълта и на изречението:

очаква се от читателя, че той чрез статията ще допълни липсващата в заглавието информация. Напр.:

"Да се събаря е

AbreiBen ist einfach ...

лесно ..."

РД 04.01 .1984

/Възниква въпросът: А какво е трудно?/

"Ако до вас пад-

SUIILE IlHEA ela Meleo

не метеорит ..."

rit vor die Füße fal-

Рд 17.01 .1984

len ...

/Очакват се препоръки, какво да се прави в такъв случай/

"за Перловската ре-

Uber den Perlovska-FluB

ка и ..."

und so manches andere...

Рд 18.01 .1984

В заключение установяваме, че заглавията с многоточие са един похват на журналистите да събуждат интереса на читателя повече, дори да го провокират. Вариантите на превода им на немски са избрани в зависимост от семантичния компонент на заглавието. Този вид наблюдаваме като заглавие на фейлетон, кратък разказ и др., но никога като заглавие на първата ста- 
тия на първата страница.

Превод на публицистични заглавия с тире

Публицистични заглавия с тире откриваме в българската и немската публицистика. От синтактична гледна точка те са разнообразни, но винаги се характеризират като една синтктична цялост, в която откриваме диалектично единство. В семантично отношение двете части, които са разделени чрез тирето могат да бъдат семантично тъждествени, напр.:

"Балканите - безядрена зона"

Рд 12.01 .1984

"Бобата за мир - най-
важната задача"
Рд 13.02 .1984
"Предотвратяването на ядрената катастрофа основна задача"

РД 02.02 .1984

"Опазването на природата - опазване на човека"

РД 18.01 .1984

"Активната жизнена позиция - характерна черта на младото поколение" HM 18.01 .1984

"Интензификацията и качеството - основна политнческа задача"

РД 26.01 .1984

"Oт първия ден на годината - с високи резултати"

Рд 02.01 .1984

"Предложението на дър-
Die Balkanhalbinsel - kernwaffenfreie Zone

Die wichtigste Aufgabe der Kampf um den Frieden

Hauptaufgabe - die Verhinderung einer atomaren $\mathrm{Ka}-$ tastrophe

Umweltschutz - Schutz des Menschen

Eine aktive Haltung zum Leben - Charakterzug der jungen Generation

Intensivierung und Qualität - grundlegende politische Aufgabe

Vom ersten Kalendertag des Jahres an - mit hohen Ergebnissen

Vorschlag der Mitgliedstaa- 
жавите-участнички във Варшавския договор ново доказателство за добра воля"

РД 12.01 .1984

Примери за семантично нетъждествени части на заглавия с тире, т. е. читателя не очаква втората част. След тирето е неочаквано и изненадващо съобщение. "Ремонтът - лошокачествен, а "процентните удари" - големи

РД 09.01 .1984

"защитата - на работното място"

РД 18.01 .1984

"В Тихия океан - 4000 ракети "Томахок"

РД 03.01 .1984

"Най-лесния отговор няма!"

РД 16.01 .1984

Първият от примерите на тази група представлява в семантично отнотение едно необичайно окачествяване на посочените резултати от деиствието, вторият и третият пример посочват неща или резултати от действие, които са в противоречие С даденото локално определение. В последния пример отговорът "няма" дава отрицателно впечатление.

4. 5. ТЕОРЕТИЧНИ БЕЛЕЖКИ КЬМ СЛОВОРЕДА НА НЕМСКОТО СЬОБЩИТЕЛНО ИЗРЕЧЕНИЕ

Съвсем накратко искаме да опитем основните положения на словореда в немското съобщително изречение. Това е необходимо, за да не се допускат грешки при превода на съобщителното изречение от български на немски.

Въпросите, които засягат семантичното равнище, пробле- 
мите на текста и на актуалното членение на изречението са много подробно разгледани от редица езиковеди като Агрикола /1976/, Лоренц, Войтяк /1977/, Флемиг /1965/, шмит /1967, $1977 /$, Флемиг, Хайдольф, Моч /1981/, Флайшер /1979/ и др. Въпросите, които засягат словореда на съобщителното изречение никога не могат да бъдат разгледани изолирано от въпросите на актуалното членение и на семантичното равнище на изречението, защото те са в диалектична взаимовръзка. Тук ще се обърнем малко повече към граматчния словоред, ще разгледаме моделите на съобщителните изречения и ще ги сравним с българските модели, за да се получи един сполучлив превод.

В съвременния немски книжовен език различаваме от структурна гледна точка три основни модела на съобщителното изречение, които се определят в зависимост от мястото на личната глаголна форма в изречението.

1. Stirnsatz: Лична глаголна форма на първо място. това изречение се характеризира с челното място на глаголната Форма, независимо, какъв тип изречение се разглежда /дали съобщително или въпросително или удивително/.

$\mathrm{P}$

сказ уемо

Gehen

Gehen
$\mathrm{S}$

подлог

wir

wir
A определение/допълнние jetzt.

2. Kernsatz: Лична глаголна форма на второ място.

S

подлог

Wir
P сказ уемо reisen
O A

допълнение/определение morgen.

Характерно за този модел е, че личната глаголна форма е на второ място, обикновено след подлога, но може и след друг сегмент на изречението, например след допълнението да е личната глаголна форма. Характерно е, че е на второ място в нзречението.

3. Spannsatz: Лична глаголна фрма на последно място. Глаголната форма при този тип изречение е накрая, когато се 
касае за самостоятелно изречение или тя въвежда едно подчинено из речение.

$O / A \quad S \quad P$

Wie schön

der Friede

ist!

Wo

wir

umsteigen müssen.

(nach Jung, 1982, S. 48,49)

Този структурен тип е характерен за подчиненото изречение. Във въведени подчинени изречения личната глаголна форма стои в края на изречението/краен словоред/. Крайният словоред се характеризира следователно не само с мястото на личната глаголна Форма, но и със съюз или съюзна дума /относително местоимение, въпросителна дума и др./ в началото на подчиненото изречение /Атаносова, Сугарова, 1983, стр. $178 /$.

Тези три схеми отразяват най-разпространените структури на изреченията в съвременния немски език. Те се определят според позицията на глагола.

lla една синтактична особеност на съвременния немски книжовен език трябва да се обърне особено внимание, това е т. н. предикативната рамка на изречението. Сказуемото в немското изречение се състои най-често от две или повече части: лична глаголна форма и инфинитив или причастие, глаголна представка и др. За разлика от българския език и от много други езици, частите на сказуемото в немското изречение не се "арсмдат послсдоратслно сдна слсд друга, а оо отдалонарат одна от друга. По този начин се получава рамка, която обръиа изречението. Личната глаголна форма образува началото на рамката като заема първото или второто място в изречението, а останалите части образуват края на рамката като се нареждат в края на изречението. При структурния тип с лична глаголна форма на първо място (Stirnsatz) всички части на изречението се намират в рамката. При структурния тип с лична глаголна форма на второ място (Kernsatz) вън от рамката остава само онази част, която заема първата позиция в изречението: willst du heute abend zu mir kommen?

$$
\text { рамка }
$$

Ich habe ihn mehr als

Не съм го виждала пове- 
einen Monat nicht gesehen.

Der zug fährt um 13 Uhr ab.
Не съм го виждала повече от месец.

Влакът заминава в 13 часа.

В зависимост от съставните части на рамката, различаваме следните варианти:

начало на рамката

Глагол в лична форма
Край на рамката

Partizip II oder Infinitv

/спомагателен модален/

Dieter ist vor zwei Tagen nach Berlin

gefahren.

Глагол в лична форма

- делима представка или друга делима част

Er legte den Mantel an der Garderobe

$a b$.

Глагол в лична форма

Infinitiv + Infinitiv на модален или друг глагол

Dieter hat seinen Freund um $\mathrm{Hilfe}$ bitten müssen.

Глагол в лична форма идиоматична именна част

Peter führte mit seinen Freunden ein Gespräch.

рамката на изречението може да се образува от лична глаголна форма и друга самостойна част на изречението, която е задължителна част, съгласно валентността на глагола-сказуемо. Такива части са предикативът /при глаголите sein, werden, bleiben/ и някои обстоятелствени пояснения.

Dieter steckte das Taschentuch in die Tasche.

В края на рамката могат да се струпат две или повече глаголни форми. Подчиненият глагол стои пред главния:

Ich will heute nachmittag einkaufen gehen. / a нe gehen einkaufen/ Gehen е главният глагол, непосредствено свързан с wollen - ich will gehen, a einkaufen зависи oт gehen - ich gehe einkaufen. /Атанасова, Сугарева, 1983 стр. 179-181/

тези кратки теоретични забележки са необходими за превода на публицистични заглавия, които са по форма съобщителни изречения. А сега конкретните примери ще илмстрират изложеното досега: 
4. 6. ПРЕВОД НА ПУБЛИЦИСТИЧНИ ЗАГЛАВИЯ, КОИТО ПРЕДСТАВЛЯВАТ СЪОБЦИТЕЛНИ ИЗРЕЧЕНИЯ

ТЕОРЕТИЧНИ УВОДНИ БЕЛЕЖКИ

Преводът на публицистични заглавия, конто представляват съобщителни изречения, изисква някои предварителни теоретични забележки. Като дефиниция на съобщителното изреченне ще приемем тази от Граматиката на съвременния български книжовен език /1983, том III, стр. 47/, която можем да разгледаме като съвкупност на дефинициите на съобщителното изречение в българската граматика:

"Изречения, С които говорещият /тук пишещият/ осведомява слушателя/тук читателя/ за неизвестни нему /по предложение на говорещия/ Факти, се наричат съобщителни. Съобщителните изречения се използуват не само за пряко предаване, но и за запаване на информачията, получена в различните клонове на човешкото знание, на културата и изкуството, както и на инФормацията, необходима за всекидневния живот на обществото. Те заемат голямо място и в устната реч и във всички писмени стилове на книжовния език - научен, художествен, публицистичен, административен."

Това положение в съвременния немски език е аналогично. И в българския и в немския език съобщителните изречения по строеж биват твърле разнообразии - Пълни и елиптични, Глаголни и безглаголни.

При превода на публицистичните заглавия, които представляват съобщителни изречения, трябва да обърнем внимание на няколко особености на словореда на българското и на немското съобщително изречения, без да си поставим за цел да изясним всички въпроси на словореда, които не могат да бъдат разгледани в рамките на тази глава.

Известно е, че в съвременния български книжовен език, от гледна точка на нейния норматив не съществува един, точно установен, определен словореден модел, съобразно с линейното разположение на частите на изречението, както съществува например в английския език - моделът S - P - 0 . 
Георгиева/1974/ Говори за наличието на най-малко три почти равномерно разпространени словоредни структурни типа. това са:

1 .

$\mathrm{S}$

$\mathrm{P}$

0

A

подлог сказуемо допълнение ${ }^{\mathrm{X}}$ обстоятелство

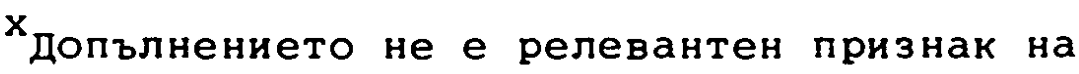
глагола-сказуемо в изречението. То или се появява, или не се повлиява от граматическото, а от лексикалното значение на глагола.

Hanp.:

"Електрониката търси своето място навсякъде"

РД 12.01 .1984

Die Elektronik sucht sich ihren Platz überall

"Офансивата се развива успешно"

РД 11.01 .1984

Die Offensive entwickelt sich erfolgreich

"Вашингтон прикрива следите"

РД 08.01 .1984

Washington verwischt die spuren

2 .

$$
P
$$

$S$

"Разширява се телефонната мрежа" РД 04.01 .1984 сказуемо - подлог /различно положение на обстоятелствата, в публицистичните заглавия в повечето случаи те липсват/

"изгражда се пощенската палата"

Рд 03.01 .1984

"Разиграва ce поредният Фарс"

Рम 11.01 .1984

3 .

A

$\mathbf{P}$

S

обстоятелство сказуемо подлог

Hanp.:

"И днес се раждат герои" РД 12.01.1984 
Посочените примери показват, че българският книжовен език се характеризира най-малко с три нормативни типа словоред и нито един от тях по отношение на структурно-семантичните си особености не би могъл да се обяви за вариант на всеки един поотделно или на някой друг извън посочените. Напротив, самите те вече дават структурно-семантични деривати /варианти/, получавайкн различни допълнителня значения - семантични, комуникативни, стилистични .

Причините за това явление, тази интерсна тридялба на българския словореден норматив не можем да открием с абсолютна точност и категоричност, освен това не сме си поставили за цел решеннето конкретно на този въпрос, а по-скоро да видим как се превеждат тези отделни словоредни модели, които срещаме в публицистичните заглавия много често, правилно на немски.

Трябва да подчертаем, че отнотението между трите основни члена на изречението подлог - сказуемо - обстоятелство, зависи не само от граматико-синтактичната им Функция в изречението и от структурната им обусловеност, но и от семантичното им съдържание. При първия случай с помощта иа структурно-граматическата роля на членовете на изречението се осъществява основната изреченска предикация в съвкупност с условията за нейната реализация. Вторият случай е адекватно

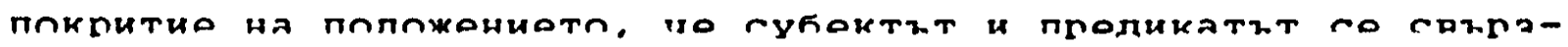
ват във времето и пространството без тяхното лексикално изразяване да влиза в задължителните условия на осъществяваната предикация. Известно $e$, че обстоятелствените терминатори са независими по отнотение на логико-граматическата категория предикация. Те обаче могат да бъдат свързани със смислови аспекти на изречението като например актуалното членение. на това място трябва да обърнем внимание на разликата между актуалното членение на изречението и актуалния словоред. Теорията за актуалното членение като изходна предпоставка взема комуникативния характер на езика. Тази теория води своето начало от такива видни представители на четкото езикознание като Матезиуз още от началото на XX. век. Известни 
са изследванията на Пр. Адамец и И. Мистрик в тази област. Така например Адамец /1966, стр. 19/ дефинира по следния начин актуалното членение:"Актуалното членение на изречението е организация на изречението $c$ цел да ce предаде актуална информация." Тази теория като подход към изучаването на изречението намери много привърженици, изтъкнати езиковеди от чешкото езикознание като Ф. Данеш, П. Мистрик, Е. Паулини и др., в Съветското езикознание И. Ковтунова, И. Распопов, О. Сиротинина, Н. Шведова и др., в българското езикознание Св. Иванчев и Е. Георгиева. Невъзможно е на това място да се изброяват всички езиковеди, които имат забележителни изследвания в областта на актуалното членение на изречението. Основно положение при разглеждане на проблематиката на актуалното членение е съотношението между веществената /семантичната/ и граматичната структура на изречението, от една страна, и актуализацията на неговите членове, от друга страна. изречението се разглежда като двуфункционална единица - като носител на веществена информация, отразена и произтичаща от лексико-синтактичната структура на дадено изречение и изразена от граматическите отношения между неговите непосредствено съставящи /членовете на изречението/ и като носител на актуална информация. Актуалната информация е този аспект на веществената информация, който в дадена ситуация говорещият /пишещият/ има намерение да съобщи на събеседника/читателя/. Теорията на актуалното членение оперира с две основни понятия - основа /тема/ и ядро /рема//Георгиева 1974, стр. $31 /$. Контекстовия словоред е словоред на текста. Той спада към синтаксиса на текста, който ние няма да разглеждаме тук, но трябва да го отбележим като разновидност на словореда. Той е пряко свързан с проявите на актуалното членение и затова е разновидност на актуалния словоред. По тази причина той не може да се разглежда сам за себе си. В непрекъснат преход от рема към тема и обратно, се гради цялостната смислова структура на текста и на всяко изречение поотделно /ГСБ KE, TOM III, CTP. $284 /$.

Емфатичен словоред наблюдаваме, когато към обективна- 
та информация се прибави едно сүбективно-оценъчно или емоционално отношение на автора на езиковото съобщение към изнасяните Факти. Когато тази допълнителна информация се предава със средствата на словореда, говори се за субективен или емоцоинален словоред, който се разбира като емфатичен словоред. При съобщителното неутрално стилистично изречение редът на темата и ремата е в посока тема --- рема.С определена цел този словореден модел се разчупва и по този начин вниманието на читателя или слушателя направо ще се прикове. Това важи особено за художествената литература, за по-големитр текстове.

Освен чрез словоредни размествания, емоционалност на изказването се осигурява чрез използуване на логическо ударение, което се проявява в условията на устната реч. И чрез лексикален път, чрез употреба на възклицания, напр. може да се постигне емоционалност на съобщителното изречение /ГСБКЕ 1983, том III, стр. 285/. Но последните два варианта не могат да се реализират в публицистичното заглавие.

Трябва да отбележим и инверсията, която е словоредна промяна. Тя разчупва трайни и установени словоредни принципи. Тя осъществява преднамерено и засяга само определен вид синтактични явления, най-често тези, които имат или рядко имат участие в комуникативното преустройство на изречението. Инверсия има тогава, когато словоредното разместване не е прелизвикано от нуждата ла се изтъкне сыпетвената в инФормацията част/когато се касае за актуален словоред/, а когато се преследват словоредни структури с определени ритмични или стилистични цели /ГСБКЕ, 1983, стр. 185/. Но ннверсия като похват в публицистичните заглавия откриваме изключително рядко.

В заключение относно словореда на изречението в българския книжовен език можем да кажем, че словоредът отразява разположението на синтактичните единици в изречението като база за изграждане на комуникативните типове структури.

Съществени за актуалния словоред са термините неутрален словоред и емфатичен словоред, които веднага сигнализират равнището, върху което се извършва квалифицирането /тези обо- 
значения правят излишно използуването на термините обективен и субективен словоред/. Всички езикови явления, които не се отнасят към граматико-семантичната структура на нзречението и чрез това към граматичния словоред или към инверсията, попадат в обсега на актуалното членение и на актуалния словоред. При случанте на съвпадение на граматичния и на актуалния словоред говорим за актуално-граматичен словоред.

Изясняването на тези проблеми е особено ценно за преводната практика, което це докажат примерите. Георгиева /1974, стр. 125/ пише: "Грешките и непоследователностите в практиката често идват като резултат от разпространеното мнение, че българския словоред е граматикализиран, поради което не позволява и не търпи разчупване на словоредните му рамки. Поради богатството от интонационни н Формални средства, българският език е успял да си осигури по-голяма словоредна свобода и гъвкава изреченска линия."

Както твърдят нашите наблюдения върху български публицистични заглавия, в заглавията срешаме почти само прости изречения. Това положение се обяснява с изискванията към публицистичното заглавие - да бъда кратко, стегнато, без излишни елементи. Затова ограничихме теоретичните уводни бележки само върху простото изречение. При самия превод прилагаме граматичните закони. ще обърнем внимание върху българските и немските схеми и модели на изречението, за да бъде превода точен.

Ако се опитаме да класифицираме публицистичните заглавия, конто представляват прости съобщителни изречения, според моделите, представени на предишните страници, преводът им ще бъде систематизиран по същия начин и резултатите ще се разберат по-ясно:

Словореден структурен тип: /39,38/

$\mathrm{S}$

подлог
0

допълнение
A обстоятелство

В публицистичните заглавия наблюдаваме и един най-кратък вариант на този словореден модел, състоящ се само от 
$\mathbf{S}$

P

подлог

ห

сказуемо, без допълнение и обстоятелст-

вено пояснение.

Например :

"Чаят поскъпва"

Tee wird teurer

РД $11.01,1984$

"Равнището задължава"

Das Niveau verpflichtet

РД 22.01.1984

"Денят започва"

Der Tag beginnt

РД 06.02 .1984

"Конгресмени протестират"

Kongreßabgeordnete protestie-

Рд 12.02 .1984 ren

"шамир заплашва"

Shamir droht

Рд 12.02 .1984

"Ваканцията започна"

Ferien haben begonnen

РД 02.01 .1984

"Протестът се засилва"

Protest wird stärker

РД 03.01 .1984

"Доверие се печели"

Vertrauen wird gewonnen

РД 18.01 .1984

Втората разновидност на този модел е словоредната структура:

3

$\Gamma$

0

подлог

сказуемо

допълнение

/липсва обстоятелствено пояснение/

Примери :

Джон Лемън разстрелва

John Lemmon erschießt die

овчарите" Schäfer

РД 16.02 .1984

"САщ покровителствуват

USA schützen Rassistenregime

расисткия режим"

РД 16.02 .1984

"Патриотите предлагат

Patrioten schlagen realistiреалистично разрешение" sche Lösung vor

РД 20.02 .1984 


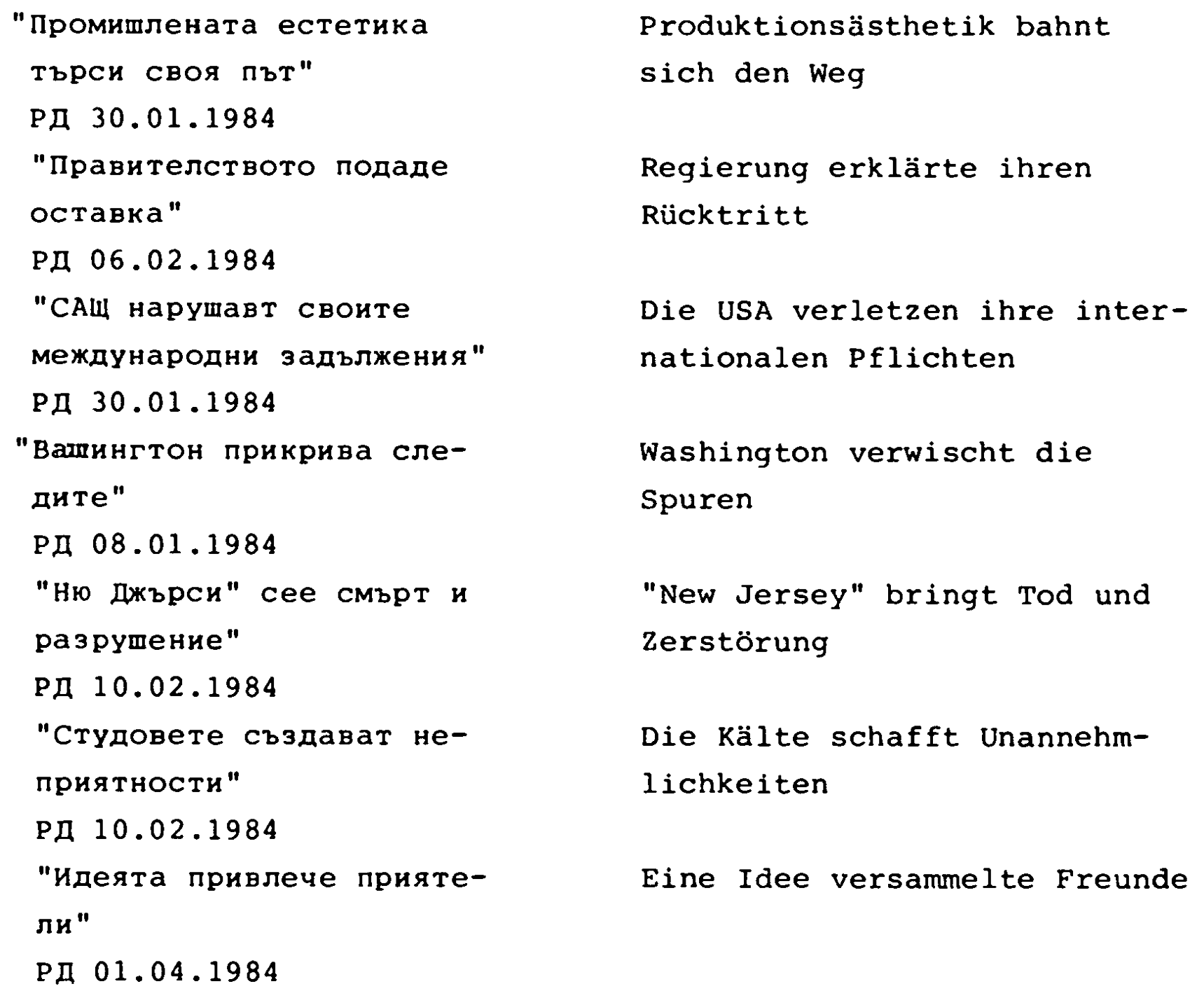
Третата разновидност на този модел е словоредната струк- Typa:

$S$

$\mathrm{P}$

A

подлог

сказуемо

обстоятелственно по-

яснение

например:

"национално-прогресивните

National-progressive Kräfte

сили настъпват успешно"

operieren erfolgreich

РД 16.02 .1984

"Електрониката търси

Elektronik sucht sich überall

своето място навсякъде"

einen Platz

РД 11.01 .1984

"Трансплантацията излиза

Transplantation geht vom La-

от лабораториите"

bor aus 
РД 11.01 .1984

Словореден тип: $/ 48,58 /$

$\mathrm{P}$

$\mathrm{S}$

o

сказуемо пдлог

допълнение

Този тип на словоредната структура може да се преведе на немски с различни варианти. Не винаги ще бъде възможно, сказуемото да бъде началната позиция, както при българските примери :

"Завършиха Мартенските März-Musiktage gingen zu Ende музикални дни"

Рд 01.04 .1984

"Расте интересът към академичните издания"

Рд 15.02 .1984

"Отварят вратите учи-

лища и детските гра-

дини"

Рд 03.01 .1984

"Увеличават се изделията с оценка "

РД 09.01 .1984

"Разширява се търговската мрежа"

РД 13.01 .1984

"Увеличава се материалната база"

РД 15.02 .1984

"Обсъждат се икономически проблеми"

РД 24.01 .1984

"обсъжда се агресията"

РД 07.01 .1984

"Възражда се шовинизмът"

РД 12.02 .1984

"Подготвят се избори"
Interesse an akademischen

Ausgaben steigt

Die Schulen und Kindergärten

öffnen ihre Pforten

Immer mehr Erzeugnisse mit der Note "Q"

Netz der Handelseinrichtungen wird erweitert

Materielle Basis wird vergrößert

Wichtige wirtschftliche Fragen besprochen

Verurteilung der Agression

Auferstehung des Chauvinismus

Wahlen werden vorbereitet 
РД 10.02 .1984

/с възвратни глаголи/

"Представят се млади

Junge sowjetische Künstсъветски художници" ler stellen sich vor

РД 21.02 .1984

Последните три примера пак бихме могли да разгледаме като подгрупа на словоредния модел $\mathrm{P}-\mathrm{S}-\mathrm{O}$, тъй като те се състоят само от сказуемо и подлог и най-концентрирано представят информацията. Вариантите на превода на немски посочват, че вербални и номинални възможности съществуват равноправни в немския език. Относно словореда se забелязва много ясно, vе българската словоредна структура $\mathrm{P}$ - $\mathrm{S}$ в тези примери е неприложима, немският словоред изисква S - P в тези случаи .

Въпросите на превода на публицистични заглавия, които представляват прости изречения показват ясно, че те представляват високи изисквания към преводача относно неговите знания върху българското и немското изречение /правилен словоред, правилна употреба на предикативната рамка, конкуренция на употреба на вербални и номинални форми в немския език/.

Словореден тип: /12,28/

A $\mathbf{P}$ $S$

обстоятелство сказуемо подлог

например:

"И днес се раждат герой"

Auch heute gibt es Helden РД 12.01 .1984

"Вече се прилагат в практиката" Bereits in der Praxis anРд 06.01 .1984

gewandt

Примерите от последния словореден тип срещаме по-рядко, те се използуват от журналиста главно с целта да се изтъкне обстоятелството за време.

А преди да разгледаме превода на публицистични заглавия които представляват въпросителни изречения от български на немски, трябва да обърнем внимание върху един тип загла- 
вия, с ранг на съобщително изречение, който не се среща много често в българската преса, но заслужава внимание относно превода на чужд език във връзка с употребата на определена членна форма в чүждия език.

Превод на български публицистични заглавия, които се състоят само от едно име /нечленувани/

Тип: Сынестително име:

в заглавията от тази категория почти не се срещат съществителни с конкретно значение, а те са повече с абстрактно, отвлечено значение. Това ще докажат и примерите, първо няколко с абстрактно значение:

"Неспокойствие"

Unruhe

РД 20.01 .1984

"Мнение"

Meinung

РД 05.12 .1979

"памет"

Erinnerung

РД 18.12 .1979

"Сътрудничество"

Zusammenarbeit

HM 28.11.1979

"Съревнование"

Wettbewerb

HM 29.11.1979

"Cтановище"

Standpunkt

HM $18.12 .19 / 9$

"Проблем"

Problem

HM 23.12.1979

$\begin{array}{ll}\text { "убеждения" } & \text { Uberzeugung } \\ \text { НМ } 11.12 .1979 & \text { Entfernungen } \\ \text { "Разстояния" } & \\ \text { РД 16.02.1984 } & \text { Uberlequngen } \\ \text { "Размисъл" } & \text { РД 16.11.1979 } \\ \text { Заглавия със съществителни с конкретни /веществени/ } \\ \text { значения } & \\ \text { "Делегати" } & \text { Delegierte } \\ \text { НМ 28.12.1979 } & \end{array}$


"Пътници"

HM 27.10 .1973

"Фоторепортаж"

HM 11.11 .1979

Ветерани"

РД 10.02 .1984

"Наставници"

РД 20.01 .1984
Reisende

Fotoreportage

Veteranen

Erzieher

Тук трябва да отбележим относно превода на нечленувани заглавия от този тип на немски следното: Посочените тук еквиваленти са точни, както на синтактично, така и на семантично равнище. Но трябва да се отбележи, че такива заглавия, т. е. само едно нечленувано съществително в публицистиката на немските вестници "Нойес дойчланд" и "Юнге Велт" са сравнително редки явления, което се дължи на граматичните норми относно членуването на съществителните в немския език, това трябва да знае преводачът. Түк трябва да се обърне специално внимание върху категорията определеност, която в българския и в немския език има формални показатели /употреба на членна Форма/. Този въпрос, който заслужава голямо внимание и който в българската граматика /напр. въпросът за съществуването на неопределителна членна форма/ one не е съвсем решен и поставя в съпоставителен план още много въпроси. Основавайки се на Л. Андрейчин /1978/, Ст. Стоянов /1980/, К. Гутшмит /1976/ Р. Римшнайдер /1982/ към този проблем, мога да обобщя за превода на този тип заглавия на немски следното:

така например когато се касае за превода на този тип заглавия като "Мнение" РД 05.12.1979 е много по-правилно то да се преведе на немски с определен член "Die Meinung" и.ли С неопределен член "Eine Meinung", когато това българско заглавие ще Функционира и като заглавие на немски в интерес на запазването на граматичните форми на немския език и на призивния характер и на възприятиетона такова заглавге от немския читател. 
Тип: Съществително име /членувано/

В тази категория срещаме съществителни с конкретно /веществено/ и абстрактно /отвлечено/ понятие. В групата на членуваните съществителни отношението между съществителните с абстрактно и с конкретно понятие е почти изравнено: Срв. /абстрактно/

"Равнището"

Das Niveau

РД 24.01 .1984

"информацията"

Die Information

Рд 22.01 .1984

"Алтернативата"

Die Alternative

HM 05.12.1979

/конкретно/

"земята"

Die Erde

РД 15.01.1984

"Майсторът"

Der Meister

РД 06.01 .1984

" Петеходецът"

Der Fußgänger

HM 28.10.1979

Примерите показват, че тези заглавия се превеждат wörtlich /дословно/ на немски и в тази форма изпълняват същата функция като бъдгарските заглавия.

Заглавията от групата на едноименните заглавия, които съдържат само едно прилагателно име, макар че се срещат рядко в българската преса се превеждат пак дословно на немски, напр.:

"Предсрочно"

Vorfristig

РД 13.12 .1979

Заглавията, които се състоят от две съществителни имена и са свързани чрез съюза "и" се срещат в немската преса съио, техният превод не затруднява:

"Интереси и качество"

Interessen und Qualität

Рम 14.01 .1984

"Единодушие и спло-

Einmütigkeit und Einigтеност" keit 
РД 16.01 .1984

"Оптимиз зм и увереност"

РД 02.01 .1984

4. 7. ПРЕВОД НА ПУБЛИЦИСТИЧНИ ЗАГЛАВИЯ, КОИТО ПРЕДСТАВЛЯВАТ ВЬПРОСИТЕЛНИ ИЗРЕЧЕНИЯ

Като дефиниция на въпросителното изречение ще приемем тази на ГСБКЕ, том III, Стр. 49 :

"Изречения с които говорещият/пишещият/ посочва на слущателя/читателя/ непълноти в своята информация, като желае информацията му да бъде попълнена чрез отговор, се наричат въпросителни. Въпросителните изречения играят важна роля в процеса на общуване, тъй като спомагат да се обменя именно необходимата, а не излишна информация между говоритедя/пишещият/ и слушателя/четящия/. Важна е ролята на въпросителните изречения и в процеса на човешкото познание изобщо, тъй като осъзнатото незнание, формулирано в определен въпрос, е първата стъпка към знанието."

В публицистиката въпросителните изречения не само разнообразяват публицистичните заглавия, но и привличат вниманието на читателя повече.

При превода на този тип заглавия трябва да се обърне внимание на особеностите на семантиката на отделните групи на българските въпросителни изречения. Следните групи се откриват при формално-семантичната класификачия на въпросителните изречения в българските публицистични материали.

Превод на въпросителни изречения С въпросителна дума: Тези изречения са три вида:

а/ Превод на въпросителни изречения с частица: /Наблюдавани са в публицистичните заглавия предимно въпросителни изречения с частицата "ли". По строеж тези въпросителни изречения С частица биват два вида:

Превод на единични въпроси, чийто отговор представлява положителна или отрицателна форма на едно и също изречение, напр.: 
"Ндва ли времето за

първия медал?"

РД 22.01.1984

"Умеем ли да почиваме?"

РД 09.01 .1984

"Розови ли са очилата

на оптимизма?"

Рд 08.01 .1984

"ще свършат ли игрите

в неделя?"

Рд 16.02 .1984

"ще се разплете ли възельт на брака?"

РД 03.05 .1984

"Умеем ли да стопа-

нисваме?"

РД 09.01 .1984

В немския език Отговорът на тези единични въпроси също представлява положителна или отрицателна Форма на едно и съио изречение, напр.:

Умеем ли да почиваме?

Да, умеем да почиваме

Hе, не умеем да почиваме.

Примерите показдат. че лори словорепа на отговорите

съвпада, само в немския пример обезателно трябва да фигурира личното местоимение, което се изразява в българския език чрез личната глаголна форма.

Разделителни /дисюнктивни/ въпроси:

Тук е невъзможен само отговорът да/не, тъи като от такъв отговор не става ясно, коя от предложените възможности се прнема или отрича. Примери:

"Определен случай или

Ein Einzelfall oder mehr?

нешо повече?"

Рд 05.01 .1984

"Отпаднал или изключен?"
Weggefallen oder ausgeschlossen? 
РД 10.01 .1984

"Истинско име или псевDer wahre Name oder ein доним?" Pseudonym?

РД 15.01 .1984

Дисюнктивът "или" се превежда на немски чрез "oder", който притежава същата функция, превода на тези въпроси не представлява трудности, както сочат преведените заглавия.

6/ Превод на въпросителни изречения с пълнозначни въпросителни думи:

Пълнозначни въпросителни думи са въпросителните местоимения и наречия кой - wer, какво - was, колко - wieviel, къде - wо и др. Тези въпросителни изречения не изискват отговор да/не, а отговор, в който вместо въпросителната дума трябва да се употреби друга дума или изречение.

При превода на този вид публицистични заглавия трябва да се обърне внимание на словореда на немското въпросително изречение /по-специално на мястото на глагола/, напр.:

"Кой защитава радостта"

РД 08.05 .1984

"Какво оме е нужно за

една приятна и полезна

почивка?

РД 17.01 .1984

"Кой губи от ограничава-

нето на контактите?"

"Какво още дава ябълката?"

РД 15.01.1984

"на кого да се сърдим?"

Рд 01.04 .1984

"Къде е изгодата?"

Рд 20.02 .1984

"Къде е дирята на подвига?"

Рд 15.01 .1984

"Къде е пазарът?"

Рд 04.01 .1984
Wer verteidigt die Freude?

Was ist notwendig für einen angenehmen und vollwertigen Urlaub?

Wer verliert durch die Einschränkung der Kontakte? Was enthält der Apfel noch?

Wem sollen wir böse sein?

Wo ist der Vorteil?

Wo ist die Spur der Heldentat?

Wo ist der Markt? 
"Какво не достига?"

РД 18.01 .1984

"Защо продължава вносът

на машинни масла?"

РД 09.01 .1984

"Защо не понскахте

думата?"

РД 05.01 .1984

Интересни са и безглаголните въпросителен характер, които често пъти дори имат провокиращо въздействие върху читателя: Напр.:

"Промени?"

РД 16.01 .1984

"А поуката? Амбицията?"

РД 09.01 .1984

"Мрачни хоризонти?"

РД 16.01 .1984

"Рекорден брой участници?"

Рд 01.04 .1984

Тези примери са преведени сега дословно като изхождаме от съдържанието /семантичното/. Но като заглавия в немските вестници не бихме предложили такъв еквивалент, един глаголен вариант е по-добър в тези случаи.

в/ Въпросителни изречения С пълнозначни въпросителни думи и С въпросителна частици са рядкост, напр.:

"Къде ли е пределът?" Wo ist wohl die Grenze?

Рд 12.02 .1984

Както показаха тези примери, проблемите около въпросителните изречения са интересни, от страната на читателя те се приемат добре, както в българската, така и в немската публицистика.

4. 8. ПРЕВОД НА ПОДБУДИТЕЛНИ ИЗРЕЧЕНИЯ КАТО ПУБЛИЦИСТИЧНИ ЗАГЛАВИЯ

В българската и в немската граматика под подбудително 
изречение се разбира изречение, с които говорещият / пишещият/ подтиква към действие, респ. към прекратяване на действие или иска позволение за извършване на дадено действие. /ГСБКЕ, 1983, том III, Стр. $68 /$.

В комуникативен план подбудителните изречения се различават според силата на волеизявата, която се определя също от социолингвистични фактори /например в публицистиката преобладава официално отношение между журналиста и читателя /.

В българските публицистични заглавия се наблюдават два вида /от граматична гледна точка/ подбудителни заглавия, глаголни и безглаголни:

а/ Превод на български публицистични заглавия, конто представляват глаголни подбудителни изречения:

"влизай, без да чукаш!"

Eintreten, ohne anzuklopfen!

Рд 13.01 .1984

"не както можеш, а както Nicht so, wie es geht, sonтрябва!" dern so, wie es sein soll!

РД 08.01 .1984

"... Искам да си поживея!" Ich möchte etwas vom Leben Рд 16.02 .1984

"запознайте се: Илютин!"

Рд 06.02 .1984

"Елате в планината!" haben ...!

Macht euch bekannt: Iljuschin!

Рд 03.01 .1984

"Моля Ви, спрете!" Kommt ins Gebirge!

Рд 06.01 .1984

Пряко обръщение в публицистиката към определено лице се превежда по следния начин:

"нужни са дела, г-н президент!"

Taten sind notwendig, Herr Рд 18.01 .1984 Präsident!

6/ Безглаголните изречения в публицистиката са изключително разнообразни. Наблюдаваме много наречия и словоредът 
е често емфатичен, не е неутрален, с целта да се засили подбудата. Напр.:

"Винаги "Пълен напред"!"

Immer "Volldampf"

Рд 07.01 .1984

"Ритмично, всеки ден,

Gleichmäßiger Rhythmus,

всеки час!" täglich, stündlich!

Рд 30.01 .1984

"Тенденция - покачване!"

Tendenz - steigend!

РД 18.01 .1984

"Предсрочно!"

Vorfristig!

РД 30.01 .1984

"Справедливо! Заслужено!"

Gerecht und wohlverdient!

РД 30.03 .1984

"Убедителни финалисти!"

Uberzeugende Finalkämpfer!

РД 09.01 .1984

При тези заглавия от типа на подбудителните изречения наблюдаваме най-голямото разнообразие на вариантите на превода на немски. Тук възможностите за превода са малко посвободни, важното при тези заглавия $е$, да се запазва призивният им характер.

4. 9. ПРЕВОД НА ПУБЛИЦИСТИЧНИ ЗАГЛАВИЯ, КОЯТО ПРЕДСТАВMЯRAT ЖFПАTFПНИИ ИЗРFЧFНИЯ

Желателни се наричат изреченията, $c$ които говорещият само изказва пожелание за извършване на дадено действие, тъй като става дума за такива процеси или за такива вършители, на които говорещият/пишещият/ не може да въздействува в момента на речта или изобщо /ГСБКЕ, том III, 1983, стр. 71/. В публицистиката желателните изречения се наблюдават сравнително рядко, в определени случаи, когато предстои едно определено събитие, тези желателни изречения са повече идиоматични изрази, които са в българския и в немския език устойчиви единици на речта, срв.:

"Добре дошла 1984 !

Sei uns gegrüßt, 1984 ! 
Бъди мирна и честита!

Рд 01.01 .1984

"Сурва, сурва година да е мирна и честита!

РД 01.01 .1984

"Да бъде плодородна! ..."

РД 01.01 .1984

"На добър час, алпинисти!" РД 21.02 .1984
Ein friedliches und glückliches neues Jahr!

Alles Gute für das neue Jahr!

Ein fruchtbares neues Jahr!

С тези примери приключваме на пите наблюдения върху превода на български публицистични заглавия от български на немски .

В резюме можем да кажем следното:

Преводът на безпредложните публицистични заглавия от български на немски не крие неочаквани проблеми, обърнато е внимание на особеностите на членуването при немските и българските заглавия.

Изключително интересен е преводът на българските публицистични заглавия, които са по форма предложно-именни словосъчетания. Открихме много варианти на превода им на немски език. Като tertium comparationis ce ориентираме предимно върху семантичното съдържание, но и върху структурните различия е обърнато подробно внимание. Изключителното разнообразие на българската предложна система изисква подробни познания от преводача относно десемантизацията на най-разпространените български предлози на, за, от, из, с, по, и др., които ясно онагледяват аналитичния характер на съвременния български книжовен език. В публицистичните заглавия намерените предлози са разгледани в глава първа, а сега, при превода им на немски се установи тяхното семантично богатство още повече. Така например, повече от половината на разгледаните предлози имат два, даже три и повече значения, които са отразени на немски чрез различни предлози или падежни форми.

При публицистичните заглавия, които са по форма прости съобщителни изречения се открива голямо разнообразие. От- 
осно словореда се установи, че в българските публицистични заглавия словоредът е малко по-свободен, макар че можем да приложим три модела на словоредната структура. Граматикализацията не е окончателно установена, което позволява по-голяма свобода и гъвкавост на изреченията. Това е положително за публицистиката и позволява различни изразни възможности, различни варианти при оформянето на публицистичното заглавие. При превода на немски е обърнато внимание на съответния словоред и там наблюдаваме често явлението, че номинални и вербални варианти могат да съшествуват равноправни в употребаTa.

Най-голямата свобода при превода наблюдаваме при подбудителните и желателните изречения, където във всеки език ce употребяват идиоматични единици /устойчиви единици на речта/, както в българския, така и в немския език.

Преводът на българските публицистични заглавия, които съдържат да-Форми е много интересен и дава едновременно много изводи за съвременното състояние на българския и на немския език. При този вид заглавия призивният характер се очертава много ясно.

Преводът на публицистичните материали е не само една интересна, но и отговорна задача, за преводача семантичният и призивният компонент трябва да бъдат на преден план при

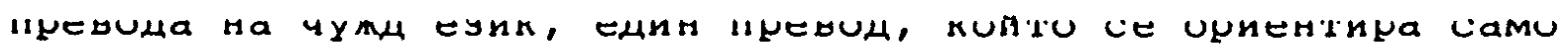
по граматичната структура няма да бъде точен, а семантичното съдържание, призивният характер и граматичната структура трябва да образуват едно диалектично единство, както в българското, оригинално заглавие, така и в немския превод.

\section{5. ЗАКЛЮЧЕНИЕ}

В края на всяка от четирите глави на дисертацията са направени обобщения и изводи въз основа на изследваните проблеми и материали, така, че няма нужда да се повтарят.

В заключение искам да отбележа следното:

Изследването на българските и немските публицистични 
заглавия в сравнителен план с оглед на еднодирекционния превод на българските публицистични заглавия на немски изисква един комплексен подход към тяхната проблематика, в граматично, синтактично, семантично и Функционално отнотение.

Във всяка глава има резултати и обобщения, но като главни изводи можем да посочим следните:

1. Тази работа, която в първата глава разглежда структурата /граматико-синтактична/ на българските публицнстични заглавия с оглед на някои Функционални аспекти, твърди преди всичко, че в съвременната българска публицистика като заглавия се предпочитат от автора субстантивни словосъчетания, което е ясен израз на аналитичния характер на българския език. Наблюдава се съгласуването и свързването чрез предлози, които в тези заглавия не изчерпват всичките си семантични Функция и възможности. Установявам преди всичко главните им значения за изразяване на предназначение /кое - за какво?/ и локално определение /кое - къде?/. темпорално определение /кое - кога/ и каузално определение /Кое - заио/, които съвпадат с основните функция на вестника, да поднесе главно в тези аспекти информацията на читателя.

Oт синтактична гледна точка наблюдаваме в анализа на българските заглавия едно максимално изпускане на глаголните форми и голям стремеж към езикова икономия, нешо, което предава на тези заглавия една известна статичност. Но чрез тази работа, която наблюдава заглавията на най-големите вестници на НРБ "Работническо дело" и "Народна младеж" в периода от 1979 до 1985г. е посочена тенденцията към едно по-динамично оформление на заглавията чрез повече вербални Форми н да-конструкцин например.

2. В анализа на немските заглавия на най-големите вестници на ГДР "Нойес Дойчланд" и "Юнге Велт" се установи, че и в немския печат има явно предпочнтане субстантивните словосъчетания, тенденцията към номинализацията и езиковата икономия и там е изразена, но не в такава голяма степен, както в българските заглавия. Срешат се много повече вербални словосъчетания, партиципиални и инфинитивни конструкция 
/срв. Глава втора и трета/. Синтетичният характер на немския език е ясно изразен чрез рекциите на отделните предлози и глаголи, среща се същото положение, както в българския език, че ce употребяват само най-важните предлози в техните главни значения за изразяване на определените значения.

3. При унилатералния превод на българските заглавия на немски език трябва да има един цялостен подход към тази задача. Преди всичко трябва да се обърне внимание на съдържанието и призивния характер на българското заглавие и те да ce превеждат точно чрез подходяща граматично-синтактична Форма на немски, която от своя страна трябва да отговаря на изискванията на немското публицистично заглавие.

4. Компаративният анализ посочва главните сходства и различия в немските и българските публицистични заглавия. Чрез него се добиват най-точните данни за най-често употребените видове заглавия в двата езика. Изводите от анализа се основават върху точни наблюдения.

5. Изследването на Функционалния аспект, което се ориентира върху главната функция на публицистичното заглавие да привлича внимание и на минимум място да даде максимум инФормация, се основава върху моите лични наблюдения и мнението на известни автори в тази област.

Голямото количество на анализираните заглавия дава пра-

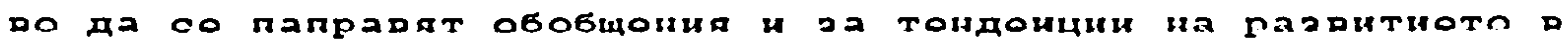
двата езика. Настоящата работа не претендира за пълна изчерпателност на изследването на абсолютно всички непа, които са във връзка с публицистичните заглавия. Тя си поставя за цел изследването на тези задачи, които са представени в нейното начало и които са разгледани в отделните глави на темата. Тази работа, която изследва българските и немските публицистични заглавия с оглед на превода на публицистичните заглавия е полезна не само в.сравнителен план, но допринася и за описанието на отделните съпоставяни езици, по отношение на езиковата типология.

Разработката върху теорията на превода с оглед на публицистичните заглавия може да намери приложение в чуждоези- 
ковото обучение, особено за студенти-филолози и преводачи и в лексикографската практика. 
1. Адамец, П., Adamec, Р., Образование предложений из пропозиций в современном русском языке. Praha: Acta universitatis Carolinae philologica. Monographia 1978

2. Адмони, В. Г., Admoni, V. G., Der deutsche Sprachbau. Moskau - Leningrad 1966

3. Адмони, ก. Г., Admoni, V. G., Zu Problemen der kontrastiven Grammatik. In: Zeitschrift für deutsche Philologie, Band 93, 1974

4. Агрикола, E., Agricola, E., Semantische Relationen im Text und im System. Berlin 1969

5. Андрейчин, Л.,Попов, К., Стоянов, Ст., Граматика на българския език. София 1977

6. Андрейчнн, Л., Основна българска граматика. София 1978

7. Арндт, E., Arndt, E., Kommunikationsbedingungen - stilbedingende Faktoren - Text- und Stilkonstruktion. In: Zeitschrift für Germanistik (Sonderdruck) Band 1, 1930

3. Арутюнова, Н. Д., Предложение и его смысл. Москва 1972

9. Арутюнова, Н. Д., О номинативной и коммуникативной моделях предложеняя. В: Известия Академия наук СССР, Серия литературы и языка, том 31, Москва 1972

10. Атанасова, В., Сугарева, Т., Кратка немска граматика. Cофит 1083

11. Березин, Ф. M., Beresin, F. M., Geschichte der sprachwissenschaftlichen Theorien. Leipzig 1980

12. Берков, В. П., Вопросы двуязычной лексикографии. Ленинград 1973

13. Бирвиш, M., Bierwisch, M., speech act theorie and pragmatics. Dordrecht, Boston, London 1979

14. Бондарко, А. В., Функцоинальная грамматика. Ленинград 1984

15. Бондарко, А. В., О грамматике функционально-семантических полей. В: Известия Академия наук СССР, Серия литературы и языка, том 43, Москва 1984

16. Бондцио, В., Bondzio, W., Einführung in die Grundfragen der Sprachwissenschaft. Berlin 1980 
17. Брезински, Ст., Журналистическа стилистика. София 1976

18. Брезински, Ст., Наблюдения върху български номинативни синтагми. Софня 1979

19. Бройер, Bräuer, H., Untersuchungen zum Konjunktiv im Altkirchenslawischen und im Altrussischen. Wiesbaden 1957

20. Р. А. Будапов, Язык, история и современност. Москва 1971

21. Валтер, Х., За някои проблеми на интерференцията на немската и българската глаголна система. В сборник:

Езиковедската българистика в ГДР. София 1982

22. Валтер, X., Zur Polysemie finiter Verbformen im Bulgarischen und ihre Monosemierung. In: Zeitschrift für slawistik, Band 20, 1975 .

23. Васева, И., Съотнотение по време между деепричастното действие и действие на сказуемо. В: Български език, кн. 3, 1961

24. Васева, И., Стилистика на превода. София 1985

25. Велева, М., Черти от семантичната характеристика на българските лични местоимения. В: Език и литература, кн. 5 1983

26. Винай, Vinay, J. P. et Darbelnet, J., stilistique compairee du français et de l'anglaise. Methode de traduction. Paris 1958

27. Виноградов, В. В., Основные вопросы синтаксиса предложения - Вопросы грамматического строя. Москва 1955

28. Вотяк, Wotjak, G., Untersuchungen zur struktur der Bedeutung. Berlin 1971

27. Вундерлих, Wunderlich, D., Linguistische Pragmatik, Wiesbaden 1975 (2. Auflage)

30. Вундерлих, Mac, Wunderlich, D., Maas, U., Pragmatik und sprachliches Handeln. Frankfurt 1972

31. Генадиева - Мутафчиева, 3., Подчинителният съюз "да" в съвременния български език. София 1970

32. Генадиева -Мутафчиева, 3., Финалните съюзи в съвременния български език. В: Български език, кн. 2, 1967

33. Георгиев, Вл., Дуриданов, Ив., Езикознание. София 1978 
34. Георгиев, Д., Режисура на вестника. София 1978

35. Георгиева, Е., Словоред на простото изречение в българския книжовен език. СоФия 1983

36. Граматика на съвременния български книжовен език в три тома, том II, Морфология, гл. редактор Ст. Стоянов, редакционна колегия: К. Иванова, П. Пашов, В. Стоянов, автори: Л. Андрейчин, П. Асенова, Е. Георгиева, К. Иванова, Р. Ницолова, П. Патов, Хр. Първев, Р. Русинов, В. Станков, К. Чолаков, София 1983

37. Граматика на съвременния български книжовен език в три тома, том III, Синтаксис, Гл. редактор К. Попов, редакционна колегия: Е. Георгиева, П. Пенчев, автори: З. Генадиева-мутафчиева, Ст. Георгиев, Е. Георгиева, А. Лазарова, Р. ницолова, П. Пенчев, Ст. Петрова, К. Попов, Ст. Брезински

38. Грим, Grimm, Н. - J., Einige Beobachtungen zum Artikelgebrauch in Zeitungsüberschriften. In: Sprachpflege, Band 9, 1981

39. Grundzüge einer deutschen Grammatik. Autorenkollektiv unter der Leitung von K.-E. Heidolph, W. Flämig und W. Motsch, Autoren: W. Flämig, B. Haftka, K.-E. Heidolph, H. Isenberg, F. Jüttner, J. Pheby, R.Steinitz, W. Wurzel, Berlin, 1981

10. Гутmмит, K., Gutechmidt, K., Zum Cobrauch dos bostimmton Artikels im Bulgarischen. Probleme der Bulgaristik, Teil II, In: Sprachwissenschaft, Leipzig 1976

41. Данеш, Daneš, Fr., Viehweger, D. (ed.), Probleme der Textgrammatik. Berlin 1976

42. Димова, А., Модални конструкции С глагола "имам" в българския език на фона на съответните конструкция в немския и английски език, В: Сборник доклади на Фбилейна научна сесия. Шумен 1982

43. Езиковедската българистика в ГДР. Сборник, съставили: Х. Валтер, К. Гутшмит, Св. Иванчев, София 1982

44. Eрбен, Erben, J., Abriß der deutschen Sprache. Leipzig 1964 
45. Есперсен, О., Оилософия грамматики. Москва 1958

46. Залевски, Salevski, H., Einführung ins Dolmetschen. Lehrbuch für Sprachmittlerstudenten der sektion slawistik der Humboldt-Universität Berlin. Berlin 1979

47. Здун, Sdun, W., Probleme und Theorien des Ubersetzens. München 1967

48. Земская, Е. А., Русская разговорная речь: лингвистически анализ и проблемы обучения. Москва 1973

49. Золотова, Г. А., Очерк Функцоинального синтаксиса русского языка. Москва 1973

50. Шлибен-Ланге, Schlieben-Lange, Linguistische Pragmatik. Stuttgart 1975

51. Сърл, Searle, J. R., Ausdruck und Bedeutung. Frankfurt 1982

52. Иванчев, Св., За актуалното членение на подлога в българския език. В: Език и литература, кн. 4, 1967

53. Иванчев, Св., За един от видовете на функционално-семантич на разграниченост на личните и показателните местоимения. В: Приноси в българското и славянското езикознание, София 1978

54. Иванчев, Св., Прилагателното под режима на аналитизма. В: Български език, кн. 4, 1983

55. Исаченко, А. В., О грамматическом значении. В: Вопросы языкознания, кн. 1, 1961

56. Исаченко, Issačenko, I. V., Die russische Sprache der Gegenwart. Teil I. Formenlehre. Halle 1962

57. Merep, Jäger, G., Translation und Translationslinguistik. Halle 1975

58. 9орданова, Л., Новите думи в съвременния български език. София 1980

59. Kaде, Kade, O., Zu einigen marxistisch-leninistischen Grundprinzipien der Ubersetzungswissenschaft der UdSSR unc der DDR. In: Beilage zu Fremdsprachen, 1964

60. Каде, Kade, O., Zufall und Gesetzmäßigkeit in der Ubersetzung. In: Beilage zu Fremdsprachen, 1, 1964 
61. Кашкин, М., Для читателя-современника. Москва 1977

62. Колер, Koller, W. , Einführung in die Ubersetzungswissenschaft. Heidelberg 1979

63. Kлопфер, Klopfer, E., Probleme und Theorien des Ubersetzens. Darmstadt 1963

64. Kleine Enzyklopädie "Deutsche Sprache". Herausgeber: Fleischer, W., Hartung, w., Schildt, J., Suchsland, P., Leipzig 1983

65. Ковтунова, И. И., Порядок слов в русским литературном языке XVIII - первой трети XIX в. Москва 1969

66. Костомаров, В. Г., Русский язык на газетной полосе. Москва 1971

67. Костомаров, В. Г., Из наблюдений над языком газеты: газетные зоголовки. В: Из опита преподавания русского языка нерусским. Москва 1965

68. Кунце, Kunze, J., Modellierung in der Linguistik und automatische Sprachverarbeitung. Berlin 1980

69. Курц, Kurz, J., Ucebnice jazyka staroslověnského. Praha 1969

70. Ленин за печата. София 1959

71. Левин, Ю. Д., Перевод и бытие литературы. В: Вопросы литературы, кн. 2, 1979

72. Левый, И., Искусство перевода. Москва 1974

73. Moñox, Loiot, $A .$, zur Intenionalitä von splechliallulungen. In: Linguistische Pragmatik, (Ed. Wunderlich) Wiesbaden 1975

74. Лемп, Lempp, А., Das zusammengesetze Verbalprädikat mit "da" im Neubulgarischen. In: Slawistische Beiträge, Band 141, München 1968

75. Леонтьев, А., Речь, язык, речевая деятельность. Москва 1969

76. Леонтьев, А. А., Психоллингвистические проблемы массовой Коммуникции. Москва 1974

77. Лилова, А., Увод в общата теория на превода. Сфоия 1981

78. Лисиченко, Lissitschenko, R., Gibt es einen Grund für die Unruhe um den deutschen Satz? In: Sprachpflege, Band I, 
1979

79. Лоренц, Вотяк, Lorenz, W., Wotjak, G., Probleme der semantischen Analyse. Berlin 1977

80. Лысакова, И. П., Язык газеты: Соцоилингвистический аспект. Ленинград 1981 /Г. С. У./

81. Людсканов, А., Превеждат човека и машината. София 1967

82. Маслов, Ю. С., Грамматика болгарского языка. Москва 1981

83. Мечкова-Атанасова, Vorlesungen zur deutschen syntax. Sofia 1964

84. Мистрик, Mistrik, J., Slovosled a vetosled v slovenčine. Bratislava 1966

85. Мирчев, Л., Към истиорията на инфинитивната форма в българския език. /Г. С. У./

86. Москальская, О. И., Грамматика текста. Москва 1981

87. Москальская, О. И., Grammatik der deutschen Gegenwartssprache. Moskau 1975

88. Москов, Н., Бояджиев, Н., Увод в езикознанието. София 1977

89. Недев, И., Оценъчни изречения в съвременния български книжовен език. В: Език и литература, кн. 3, 1982

90. Недев, И., За отношението на елипсата към комуникативния строеж на изречението. В: Български език, кн. 5, 1979

91. Николов, Б., Журналистически жанрове. София 1979

92. Ницолова, Р., Интензифициращи местоимения в славянските езици. В: Славистични изследвания, кн. 4, 1978

93. Ницолова, Р., Ролята на местоименията в емоцоиналната актуализация на изказването. В: Otacky slovenske syntaxe, IV, 2, Brno 1980

94. Ницолова, Р., Прагматичният аспект на изречението в българския книжовен език. София 1983

95. Огнянов-Ризор, Л., Основи на преводаческото изкуство. София 1947

96. Остин, Austin, J. L., How to do things with words. Oxford, London, New York 1975

97. Памфилов, Граматика и логика. София 1983

9в. Пашов, П., "Авторската" и "учтивата" форма за множествено 
число. В: Помагало по българска морфология. Имена. София 1978

99. Пашов, П., За "падежите" на местоименията в съвременния български език. В: Помагало по българска морфология. Имена София 1978

100. Пашов, П., ницолова, Р., Помагало по българска морфология. Глагол. София 1976

101. Паулини, Pauliny, E., Slovosled a aktuálne vetné členenie. B: Slovenska reč, Band 51, 1950

102. Перние, Pernier, M., Traduction et théorie lingistique appeliqueé - Exégesése et traduction. Dugue, Paris, oct. dec. 1973, nouvelle serie 12

103. Петкова- шик, Petkova-Schick, Studien zum Wesen der "da"Konstruktionen in der bulgarischen Literatursprache. In: Zeitschrift für slawistik, Band XVII, 1972

104. Пилер, 3. /Комати, 3./ Съпоставителен анализ на български и немски публицистични заглавия. В: Език и литература, кн. 4, 1981

105. Пилер, 3., /Комати, 3./, Някои наблюдения върху български и немски публицистични заглавия. В: Поклади на Първия международен конгрес по българистика. София 1981

106. Попов, С., Синтактическая структура современных газетных заголовки и её развитии. Сб.: Развитие синтаксиса совреmesinutu pyccinulo nsdina. Mulnda 1960

107. Попов, К. П., Съвременен български език. Синтаксис. София 1974

108. Попов, К. П., По някои основни въпроси на българския книжовен език. София 1973

109. Познер, Posner, R., Semantics and pragmatics of sentence conectivity in natural language. In: Bierwisch: Speech act theorie and pragmatics. Dordrecht, Boston, London 1979

110. Радева,В., Особености в словообразуването на деятелните имена за лица. Сп. Български език, кн. 4, 1974

111. Радке, К., К вопросу о функции и структуре газетных заголовков в русском и немецким языках. Jahresbericht der Uni- 
versität Greifswald 1981

112. Распопов, И. И., Строение простого предложения в современном русском языке. Москва 1970

113. Райс, Reiß, K., Texttyp und Ubersetzungsmethode. Kronberg/Taunus 1976

114. Ризел, Riesel, L., Der Stil der deutschen Alltagsrede. Moskau 1964

115. Ризел, шенделс, Riesel, L., Schendels E., Deutsche Stilistik. Moskau 1975

116. Римшнайдер, Р., Към проблема за семантиката и за Функционалните различия при употребата на определителния член в българския и немския език. В: Езиковедската българистика в ГдР, София 1982

117. Рогинский, В. М., О тенденции в развитии структуры заголовков. В: Исследования по грамматике и лекскология, Киев 1966

118. Розенталь, Д. Э., Теленкова, М. А., Практическая стилистика русского языка. Москва 1975

119. Розенталь, Д. Э., Язык и стиль средств массовой информация и пропаганды. Москва 1980

120. Розенталь, Д. Э., Язык рекламных текстов. Москва 1981

121. Pьомер, Römer, R., Die Sprache der Anzeigenwerbung. Düsseldorf 1968

122. Ружичка, Ruzicka, R., studien zur syntax und struktur dẹ modernen Russischen, Band I, Berlin 1980

123. Русская грамматика, том II, Синтаксис, редакционная колегия: Н. Ю. Шведова, Н. Д. Арутюнова, А. В. Бондарко, Вал. Вас. Иванов, В. В. Попатин, И. С. Улуханов, Ф. П. Филин, автори: К. В. Габучан, Е. А. Брызгунова, В. А. Чукович, И. И. Ковтунова, И. Н. Крушина, А.Г. Прияткина, М. В. Ляпон, И. П. Слатогор, Н. Ю. !ведова

124. Сафонов, А. А., Стилистика газетных заголовков. В: Стилистика газетных жанров, Москва 1975

125. Сиротнина, О. Б., Современная разговорная речь и её особености, Москва 1975

126. Степанов, ю. С., Методы и принципы современной лингвисти- 
ки. Москва 1974

127. Стоянова-Иовчева, С., Златева, Н., За някои синтактични особености на словосъчетанията-заглавия в немския и 5ългарския периодичен печат. В: Съпоставително езикознание, кн. 6,1984

128. Стоянов, Ст., Граматика на българския книжовен език. София 1964

129. Стоянов, Ст., Граматическата категория определеност в българския книжовен език. София 1980

130. Съpr, searle, J. R., sprechakte. Frankfurt am liain 1983

131. Трилхазе, Trillhase, G., Zur syntaktischen stuktur russischer Zeitungsüberschriften. In: Wissenschaftliche Zeitschrift der Humboldt-Universität $z u$ Berlin, Bd. 3, 1969

132. Фивегеp, Viehweger und Kollektiv, Probleme der semantischen Analyse. Berlin 1977

133. Феодоров, А. В., О художественном переводе. Ленинград 1941

134. Феодоров, А. В., Основы общей теории перевода. Мостка 1968

135. Фладер, Flader, D., Pragmatische Aspekte von Werbeslogans. In: Wunderlich (Ed.) 1975

136. Флайmep, Fleischer, W., Wortbildung der deutschen Gegenwartssprache. T.einzig 1979

137. Флайmер, Михел, Fleischer, W., Michel, G., Stilistik der deutschen Gegenwartssprache. Leipzig 1979

138. Флекенщайн, Fleckenstein, Chr., Die Tendenz zum Analytismus und ihre Erscheinungsformen in der modernen russischen Sprache. In: Zeitschrift für Slawistik, Bd. 4, 1977

139. Флемиг, Flämig, W., Zum Konjunktiv in der deutschen Sprache der Gegenwart. Berlin 1962

140. Хакел, Hackel, W., Zu einem jüngeren Typ des engen appositionellen Syntagmas. In: Deutsch als Fremdsprache, Bd. 9,1972

141. Харвег, Harweg, R., Pronomina und Textkonstruktion. München 1968 
142. Хелбиг, Буша, Helbig, Buscha, Deutsche Grammatik. Ein Handbuch für den Ausländerunterricht. Leipzig 1979

143. Хекел, Heckel, K., Fragen der Theorie und Praxis statistischer Erhebungen zur Lexik in der sowjetischen Presse, dargestellt am Zentralorgan "Iswestija". Berlin 1973

144. Уфимцева, А. А., Языковая номинация. Москва 1977

145. Шведова, Н. Ю., Русский язык. Грамматические исследования. Москва 1977

146. Швец, А. В., Разговорные конструкция в языке газеты. Киев 1971

147. Шмит, Schmidt, W., Funktional-kommunikative Sprachbeschreibung. Berlin 1977

148. Шлибен-Ланге, Schlieben-Lange, Linguistische Pragmatik. stuttgart 1975

149. Щьорих, Störich, H., Die Übersetzung (Geschichte, Theorie, Anwendung). München 1967

150. Юнг, Jung, W., Grammatik der deutschen Sprache. Leipzig 1964

151. Ягич, Jagic, V., Entstehungsgeschichte der kirchenslavischen Sprache. Berlin 1913

152. Якобсон, Jakobson. G., Gerund and Activ Participle in modern russian newspaper language. In: Scandoslavica, Bd. 14, 1968

153. Янакиев, М., Стилистиката и езиковото обучение. София 1977

Други източници: Работническо дело /Съкращение РД/ народна младеж/Съкращение НM/ Neues Deutschland / Съкрашение ND/ Junge welt /Съкращение JW/ 